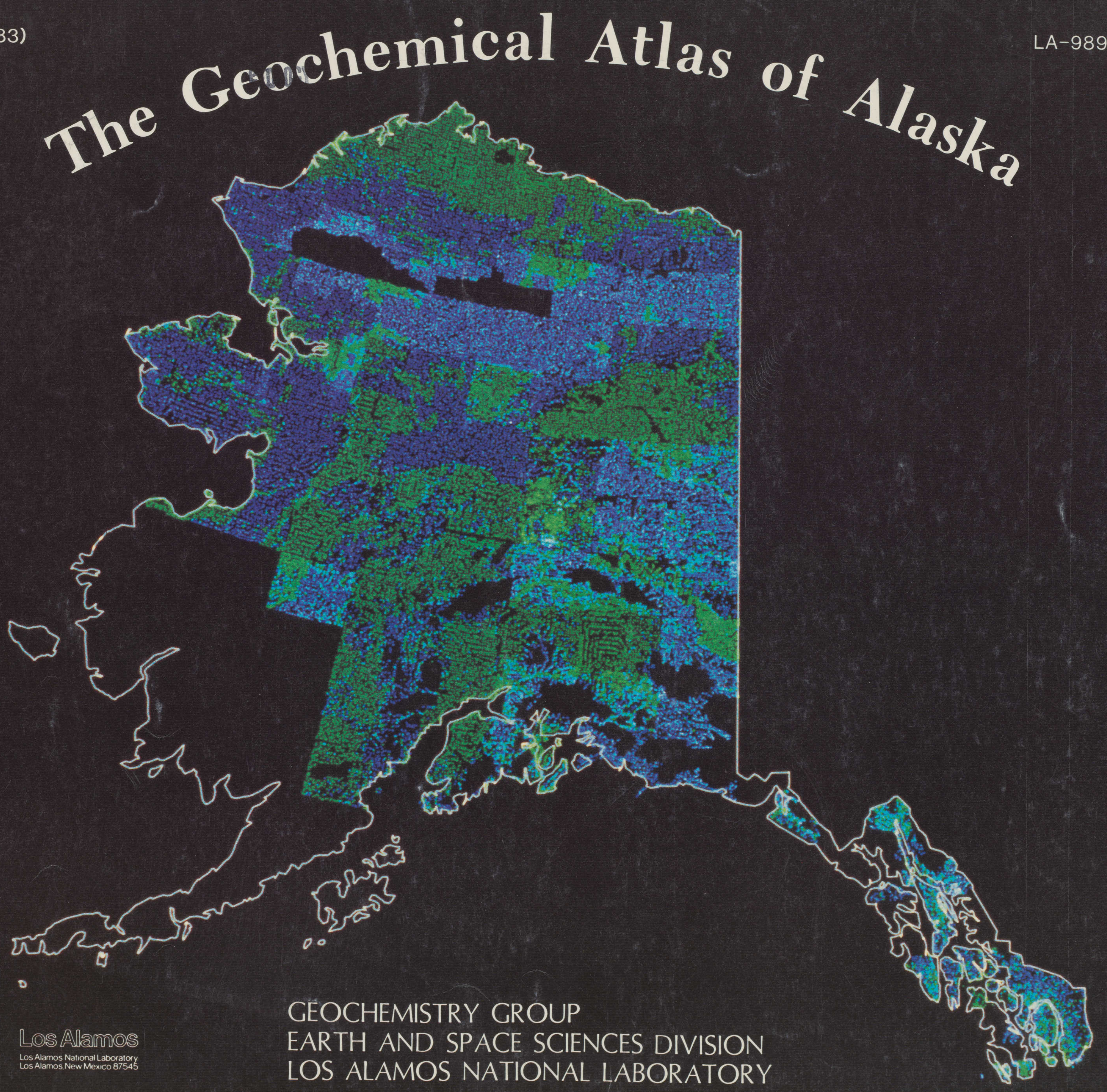


An Affirmative Action/Equal Opportunity Employer

COVER ILLUSTRATION: The display on the cover depicts the sample locations used for data in

DISCLAIMER This report was prepared a san account of work sponsored by an agency of the Unied States Government.
Neither the United States Government nor any agency thereof, nor any of theij employeses, makes any waranty, express or implied, or assumes any legal liability or responsisility for the accuracy, completeresess, or usefunhess of any information, apparatus, product, or process discised, or represents that its suse would
not infringe privately owned rights. References herein to any specific corrunercial product, process, or

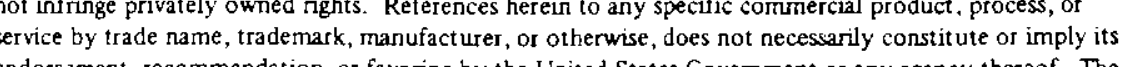

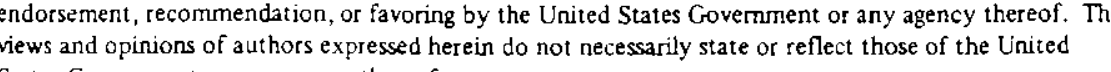

UNITED STATES DEPARTMENT OF ENERGY
CONTRACT W.7405-ENG. 30 


\section{THE GEOCHEMICAL ATLAS OF ALASKA}

LA-9897-MS UC-51

\section{COMPILED BY THE GEOCHEMISTRY GROUP \\ EARTH AND SPACE SCIENCES DIVISION \\ LOS ALAMOS NATIONAL LABORATORY \\ LOS ALAMOS, NEW MEXICO 87545}

\section{PROJECT LEADER}

Thomas A. Weaver

\section{PRINCIPAL INVESTIGATORS}

Data Processing and Atlas Production: Susan H. Freeman Geology: David E. Broxton Geochemistry: Stephen L. Bolivar

\section{ASSISTED BY}

Sampling: Field Supervisors - D.E. Hill, R.R. Sharp,Jr., P.L. Aamodt, R.G. Warren, W.A. Morris

Chemical Analysis: Delayed Neutron Counting and Instrumental Neutron Activation Analysis - M.E. Bunker M.M. Minor, W.K. Hensley, S.R. Garcia, M.M. Denton, S.L. Stein

X-Ray Fluorescence - G.R. Waterbury, J.M. Hansel, C.J. Martell, W.F. Zelezny, W.E. George, J.S. Clements, C.L. Talcott A.D. Hues

Emission Spectrography - D.L. Gallimore, C.T. Apel, D.W. Steinhaus, A.D. Hues

Data Processing: K. Campbell, R.J. Beckman, C. Mclnteer, J. Cheadle III, D.E. Hanks, D.J. Pirtle, C.F. Mills, G.J. Thomas, L.W. Maassen 


\section{SUMMARY}

The Geochemical Atlas of Alaska is a $1: 6,000,000$-scale $(1 \mathrm{~cm}=60 \mathrm{~km}$ ) pictorial representation of regional, geochemicalsurvey data acquired by the Los Alamos National Laboratory as part of the Hydrogeochemical and Stream-Sediment Reconhalssale 61,923 locations, distributed over most of Alaska, were collected and analyzed. Standardized field and analytical procedures were employed throughout. Universal kriging techniques were used to interpolate the data to a 5 -km by 5 -km grid (resulting in 46,276 grid cells), and the results are displayed as images with color and color intensity representing elemental concentrations. Single-element color plates atesplay colors (red, green, or blue) with 256 levels of color intensity representing the concentrations for each element. Text describing the sampling, chemical analysis, and data-processing procedures, accompanied by transparent overlays providing georaphic index information, sample location and type, land control, and mineral occurrence information are also included to aid and (1) geology and (2) areas of potential mineralization are likewise provided.

\section{ACKNOWLEDGMENTS}

In addition to the many able assistants listed on the title page, most of whom were involved directly in the National Uranium Resource Evaluation program at the Los Alamos National Laboratory, the authors gratefully acknowledge the efforts of Patricia ol purke and Janice Barber tword processingl, Anthony Garcla (illustration, and Glenda ponder leditingl. The corporations, and private land holders who permitted the sampling of the lands managed by them. mhe financial support of the Grand Junction office of the U.S. Department of Enerqu (for the geochemical sampling, analysis, and reporting phases and for atlas production) and of the state of Alaska is also gratefully acknowledged. Critical reviews of the atlas were kindly provided by Hatten Yoder, George Koch, Milton wiltse, and several members of the staffs of the Grand Junction offices of the Bendix Field Englneering Corporation and the Department of Energy. Their many helpful suggestions were used to improve the atlas, though the accuracy of the final product is the sole responsibility of the authors. tastiy, the authors express their

program, and to wayne A. Morris, who managed the program after bob sharp left. 
SUMMARY ...................... . . . .

ACKNOWLEDGMENTS . . . . . . . . . . . . . . iv

INTRODUCTION .......................

BACKGROUND . . . . . . . . . . . . . . . . .

METHODOLOGIES ...................... I

Sample collection ................ 1

Sample Analysis . . . . . . . . . . . . . 3

Uranium Determination by Delayed-Neutron Counting . . 3

Elemental Determinations by Instrumental Neutron

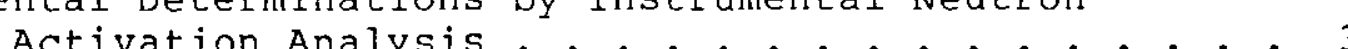

Elemental Determinations Using Energy-Dispersive

X-Ray Fluorescence ............ 3

Beryllium and Lithium Determinations by Arc-Source

Emission Spectrography .......... 4

Data Analysis . . . . . . . . . . . . 4 4

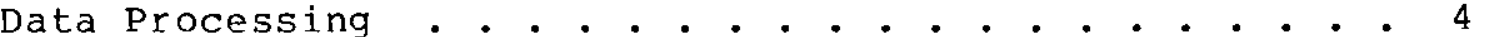

Data Display .............. . . 4

\section{EXAMPLES OF ANALYSIS AND INTERPRETATION OF ALASKAN}

GEOCHEMICAL DATA

Felsic Plutons ...............4

Utilizing Geochemical Data to Identify Areas of

Potential Mineralization ........... 6

RECOMMENDATIONS .................... 6

REFERENCES .......................

\section{ILLUSTRATIONS}

Fig. No.

1. Alaskan areas not sampled by NURE HSSR. . . . . 2

2. NURE HSSR sampling densities in Alaska. . . . . 2

3. Distribution of felsic plutons in Alaska (King, 1969)........... 5

4. Generalized geologic map of the Alaska-

Aleutian Range batholith. .......

TABLES

Table No.

I. Elements Analyzed in Sediment Samples During the HSSR .............

II. Comparison of Medians and Means for Selected Elements in Felsic Plutons with State-
wide Averages

\section{PLATES}

Plate No.

1. Generalized Geology of Alaska . . . . . . . 8

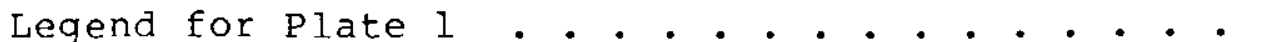

Plate No. (cont)

Single-Element Plates (Concentrations in Statistical Intervals)

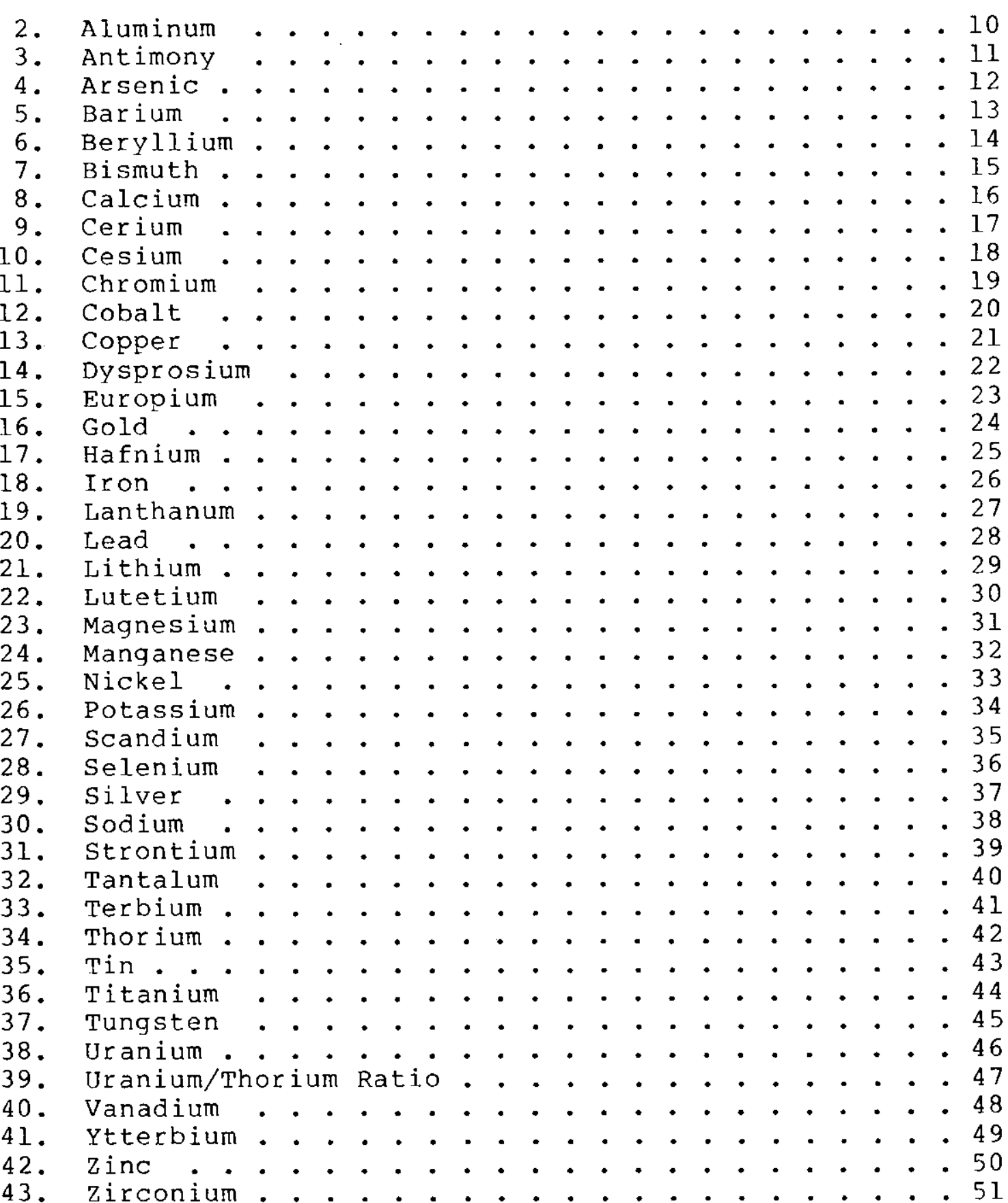

Three-Element Plates
45. Chromium-Copper-Nickel (all data) ...... 52
45. Chromium-Copper-Nickel (greater than one $\ldots . . .5$
46. Barium-Copper-Nickel (all data) mean) $\therefore . .55$
47. Barium-Copper-Nickel (all data)
4tandard deviation above the mean) . . . . 55
49. Uranium-Thorium-Hafnium (greater than on standard deviation above the mean) . . . . . 57

OVERLAYS, $1: 6,000,000$-SCALE (in Rear pocket)

Overlay No.

I. Geographic Index Overlay of Alaska

II. Quadrangle Overlay of Alaska (containing GJBX Report Numbers for Geochemical-Survey sediment Data)

III. Sample Location Overlay for Stream Sediments

IV. Sample Location Overlay for Lake Sediments

v. Land Control Overlay of Alaska

VI. Mineral Occurrences Overlay of Alaska 

INTRODUCTION

Earth science studies in Alaska are at a relatively youthful stage of development compared to those in most other areas of the United States because of the great size and remote nature of the state. Regional geochemical data published during the past five that remain about the state's geology, geochemistry, and geophysics. out much of the state and provide a comprehensive data set that can with data handling arise when using voluminous geochemical data for a large area. This atlas attempts to overcome these problems and format readily usable by researchers.

The data presented are from the Alaska portion of a nationwide, multielement, geochemical survey for uranium in the United States. Geochemical exploration has proven to be a reliable method for deter-
mining major, minor, and trace-element distributions in rocks and moils on or near the surface of the Earth (Hawkes and Webb, 1962; solis on or near the surface of the Earth (Hawkes and Webb, 1962; samples and the mapping and interpretation of the resulting data. Samples collected may include: rocks; soils; stream and lake sediments; stream, lake, well, and spring waters; and plant matter. geologic samples that represent average elemental abundances within data from the Alaskan survey have been used to compile this atlas.

The abundance and distribution of elements as determined from systematically collected and analyzed geochemical samples can provide valuable regional geologic information such as the nature of the bed-
rock and the approximate location of lithologic contacts. 作 mapped with these data. The detail with which these maps can be made depends on the sampling density (the number of samples collected per unit area). Used in conjunction with other available geochemical, geophysical, and geologic information, geochemical survey data pro-

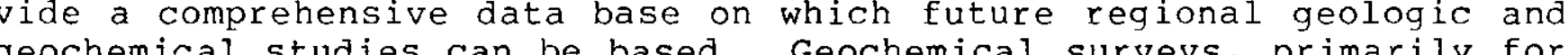
the purpose of assessing resources, have been successfuliy conducted in Australia, Canada, Finland, Germany, South Africa, the Soviet
Union, and the United Kingdom, as well as the United States.

The Geochemical Atlas of Alaska presents regional geochemical data as computer-generated images having concentration values of the images to project these dat and color intensities. The use of color overview of broad geochemical trends, place local geochemical patterns in their proper regional context, and observe some correlations among the elements presented. The methods used to compile and portray elemental concentrations in this atlas are similar to those employed
by Webb et al. (1973) and Webb et al. (1978) in their pioneering geoby Webb et al. (1973) and Webb et al. (1978) in their
chemical atlases of Ireland and of England and Wales.

One caveat cannot be emphasized strongly enough to atlas users. As stated several times by Webb et al. (1978), regional geochemical data are broad scale. For example, sampling densities in Alaska
ranged from one sample per $10 \mathrm{~km}^{2}$ to one per $23 \mathrm{~km}^{2}$. Therefore, these data cannot necessarily be used to pinpoint specific geocheminterpretation of stream-sediment and lake-sediment data is not commonly straightforward and must take into account the many factors that can influence the composition of these sediments. Stream sediments and lake sediments are two distinct sample types, each of
which is influenced by different factors, and some elements concenwhich is influenced by different factors, and some elements concenUon careful examination of the elemental plates, together with the overlays of stream- and lake-sediment sample locations, differences in some elements (e.g., iron) can be seen between the areas that were sampled predominantly from lakes and those sampled predominantly from unervable in the elemental plates. Nevertheless, for areal completeness of the atlas, both types of samples have been included in the same data base.

If utilized with proper caution, these data can be successfully used to: (1) identify broad geochemical patterns, (2) determine some correlations among those elements, and (4) select areas of the geochemical data on the color plates, there is a text section, a generalized geologic map (Plate 1 ), and various transparent overlays
(in rear pocket). All plates and overlays are at the same scale (in rear pocket). All plates and overlays are at the same scale
$(1: 6,000,000)$. The text describes the methodologies used for sample collection, sample analysis, and data processing. Examples of correlations among the geochemical data and geology and among geochemical data and mineralization, recommendations for further work, and
principal references cited are also included in the text. The overprincipal references cited are also included in the text. The over-
lays are: (I) a geographic index overlay of Alaska; (II) a quadrangle nutlay for Alaska shol-survey sediment data; (III) sample location overlay for stream sediment; (IV) sample location overlay for lake sediment; (V) land control overlay of Alaska; and (VI) mineral occur-

\section{BACKGROUND}

The regional geochemical survey that provided the data used in this atlas was conducted as part of the HSSR (Hydrogeochemical and
Stream Sediment Reconnaissance) portion of the NURE (National Uranium Resource Evaluation) program. The NURE program was initiated by the U.S. Atomic Energy Commission in 1974 and later managed successively by the ERDA (Energy Research and Development Administration) and DOE (Department of Energy). NURE was begun during a time when there was support an expanding nuclear power capacity. The purpose of NuRE was to gather data with which to make an assessment of the uranium resources in the United States, as well as to indicate to the private sector areas favorable for uranium exploration. The HSSR portion of
NURE was a nationwide, regional, geochemical survey designed to idenNURE was a nationwide, regional, geochemical survey designed to iden
tify broad areas favorable for the occurrence of uranium deposits.

Responsibility for conducting the HSSR was assigned to four national laboratories: Savannah River, Oak Ridge, Los Alamos, and Lawrence Livermore (Bolivar, 1980). Los Alamos was given responsibility for the HSSR in the Rocky Mountain states and in Alaska. Analytical and field data gathered during the program have been open
filed to the public through the Grand Junction Office of DOE (see Overlay II). These open-file reports and digital tapes contain, in analytical results. Each report or tape contains data for one or
more $1: 250,000-$ scale NTMS (National Topographic Map Service) quadrangles. In Alaska, 104 NTMS quadrangles were sampled and reported. The remaining cuts of all samples, all field data forms, and the
original field maps are now archived at the Oak Ridge Gaseous original field maps are now archived
Diffusion Plant, Oak Ridge, Tennessee.

Geochemical samples collected early in the HSSR were analyzed for uranium only because the NURE program was implemented to evaluate the uranium resources of the United States. It soon became apparent to DOE to make a complete evaluation and that it would be expedient to analyze the samples for as many elements as possible, particularly for those elements known to be associated with or suspected to be pathfinders for uranium mineralization. Consequently, each laboraanalyses that was approved by DOE. As a result, the NURE proqram has provided users with a tremendous quantity of major, minor, and trace-
element data covering approximately two-thirds of the United States.

\section{METHODOLOGIES}

The three basic steps necessary to complete this study were sample collection, sample analysis, and data processing and interpretation. The sampling program was largely patterned after successful geochemical surveys in Canada, Scandinavia, the Soviet Union, and similar terranes and climatic regimes elsewhere (Sharp, 1977;
Sharp and Bolivar, 1981; and Bolivar, 1981). State-of-the-art methods were used to analyze all samples and efforts were made to maximize the number of elements determined and the quality of the data collected. Large computers were used to process the data analytical information associated with each sample site.

\section{Sample Collection}

The sampling program in Alaska began in 1975 and by $197980 \%$ of the land area of the state had been covered. Unfortunately, no funds were available for further HSSR field work after 1979, and the southPanhandle region could not be sampled. Unsampled areas are shown in
Fig. 1. These include proposed National parks and Monuments for which permission to sample was denied after 1977 and the cores some mountain ranges covered by glaciers and extensive ice sheets. 


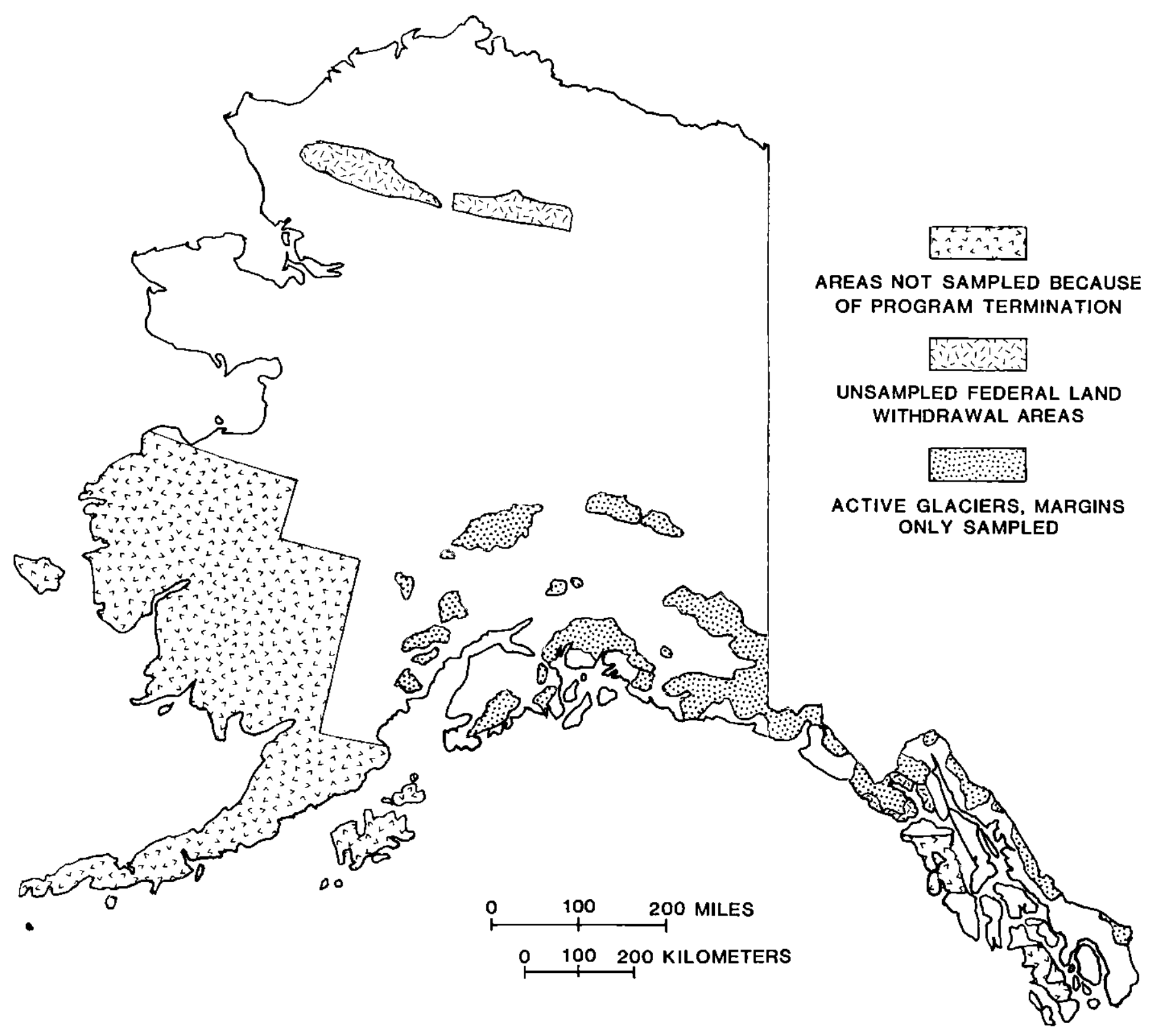

Fig. 1. Alaskan areas not sampled by NURE HSSR.

A nominal sample density of one sample per $10 \mathrm{~km}^{2} \quad\left(4 \mathrm{mi}^{2}\right)$ was selected for areas of Alaska with moderate-to-high relief and one
sample per $23 \mathrm{~km}^{2}\left(9 \mathrm{mi}^{2}\right)$ was taken in low-lying areas having abundant lakes (Fig. 2). Sediment samples from small streams wer the preferred sample type in regions having well-developed drainage low, flat areas having poorly integrated drainages. A total of 61,923 sediment samples was collected throughout the state. of these, 38,021 were from small streams (Overlay III) and 23,902 were fro
small lakes (Overlay IV).

For stream sites, a composite sample of fine-grained material was collected from three adjacent spots in the active stream bed (Sharp and Aamodt, 1978). Usually about a kilogram of such material was collected from every site to insure that there was at least $25 \mathrm{~g}$ minus 100 mesh (that material passing a 100 -mesh screen). For lake ing, a tethered, stainless steel bottom sampler was dropped near basis of an extensive survey of the literature (Sharp. i977) and pilot samplings (e.g., Olsen, 1977), a minus-100-mesh sediment sample was determined to be representative of the total sample with respect to uranium concentrations.

water samples, along with field measurements and observations were recorded included water temperature, The field measurements that conductance, and pH. Scintillometer measurements were taken at stream-sediment sites. Field observations included general descriptions of bedrock geology, stream and lake characteristics, local vegetation, terrain, and possible contaminants (if any). Field prenumbered data forms having the same number that was affixed to on corresponding sample. In each case, this was done at the sample site.

Most sampling was performed on a quadrangle-by-quadrangle basis by commercial contractors according to Los Alamos specifications. number and number and land area of the NTMS quadrangles involved were let by with sampling maps, detailed field-procedures manuals (Sharp and

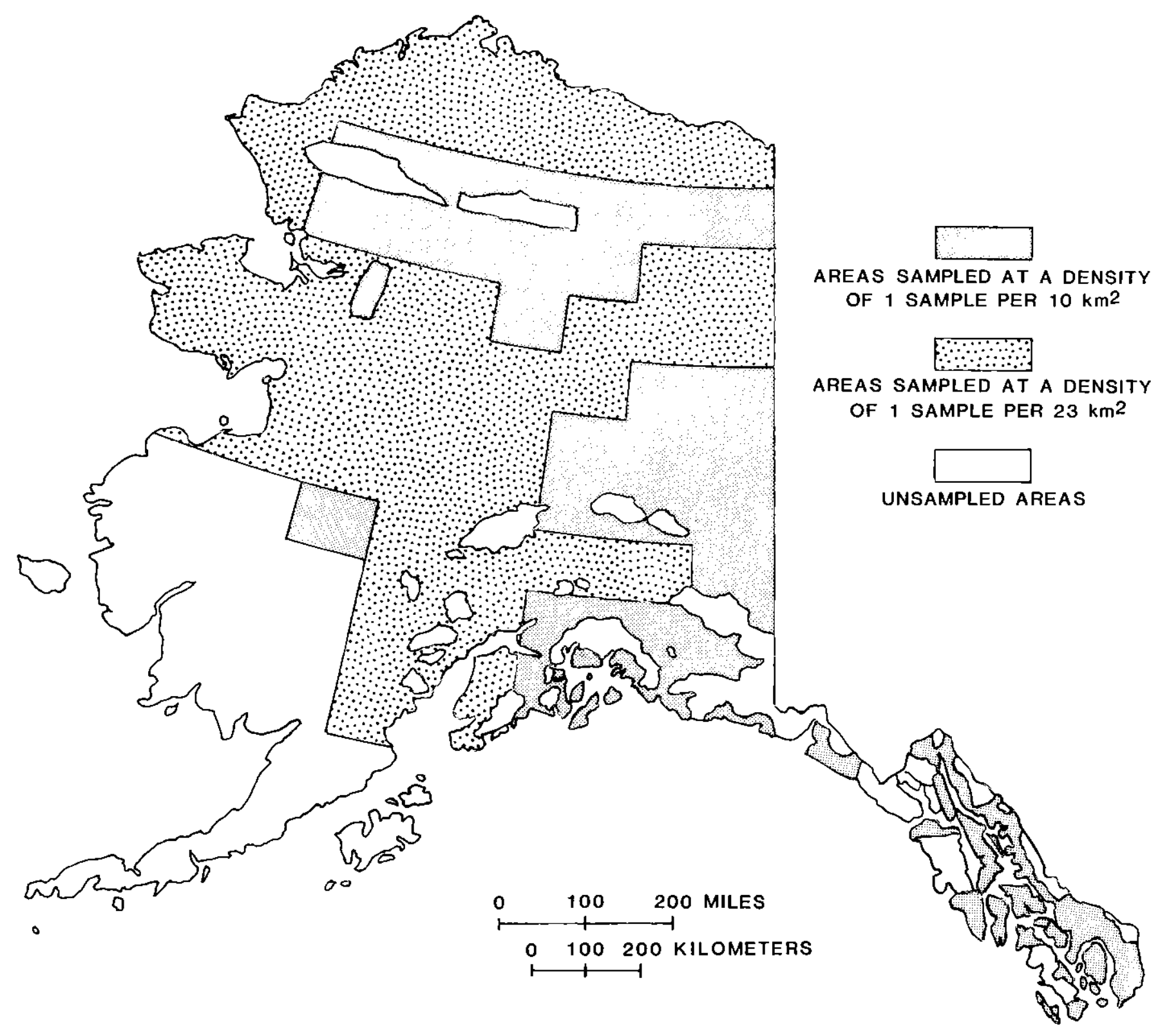

Fig. 2. NURE HSSR sampling densities in Alaska.

Aamodt, 1978), and training sessions by a Los Alamos contract monitor. At least one trained Los Alamos contract monitor or field supervisor was assigned to work with sample collectors in each field camp to answer questions about field procedures and sampling equipment and to according to specifications.

The lack of roads throughout most of the state made it necessary to sample most areas by helicopters operating from self-sufficient, portable field camps. Food, fuel, and other supplies were flown into sampling program were also typically delivered by fixed-wing aircraft. Sampling program were also typically delivered by fixed-wing aircraft. and flew designated routes to preselected sample sites. Helicopter pilots used the quadrangle maps at a scale of 1:250,000 for navigation and to mark the sites actually sampled.

During or immediately after each 8- to 10-hour sampling shift (usually carried out in 2 - to 4-hour increments), maps, samples, and samples were shipped to central processing facilities in Fairbanks or Anchorage where they were dried at $\leq 100^{\circ} \mathrm{C}$ and sieved to minus 100 was sent to Los Alamos for analysis; the remainder of the sample was (ached.

Orientation studies, designed by Los Alamos, were conducted by the Geological Survey of Alaska in 1975 and by Los Alamos personnel in 1976 to determine appropriate sampling procedures for Alaska. The first commercial contract for reconnaissance geochemical work was of samples at 4,468 locations. In 1977, two contract areas, consheets, were sampled by one commercial contractor in south-central Alaska. An additional 1,435 samples were collected in 1977 from the Fairbanks quadrangle by the University of Alaska as part of another pilot survey. In 1978, four areas that totaled approximately 28,500 sample locations from 37 quadrangles were sampled by two contractors the Brooks Range. An additional 900 locations were sampled in 1978 in the Bettles quadrangle by the University of Alaska, and 160 
samples were taken from the Dixon Entrance quadrangle area by Los Alamos in that same year. the contractor. Funds for additional sampling became available late in the summer of 1979 and Los Alamos personnel were able to sample about

\section{Sample Analysis}

Sediment samples were analyzed at Los Alamos by DNC (delayedneutron counting), INAA (instrumental heutron-activation analysis), XRF ( $x$-ray fluorescence), and arc-source emission spectrography thele 1 in from several quadrangles were analyzed only for uranium by DNC. Later, as funds became available to expand the analytical efforts. these samples were reanalyzed for a multielement suite using the other techniques. About midway through the analytical effort, improvements to the XR

TABLE I

ELEMENTS ANALYZED IN SEDIMENT SAMPLES DURING THE HSSR

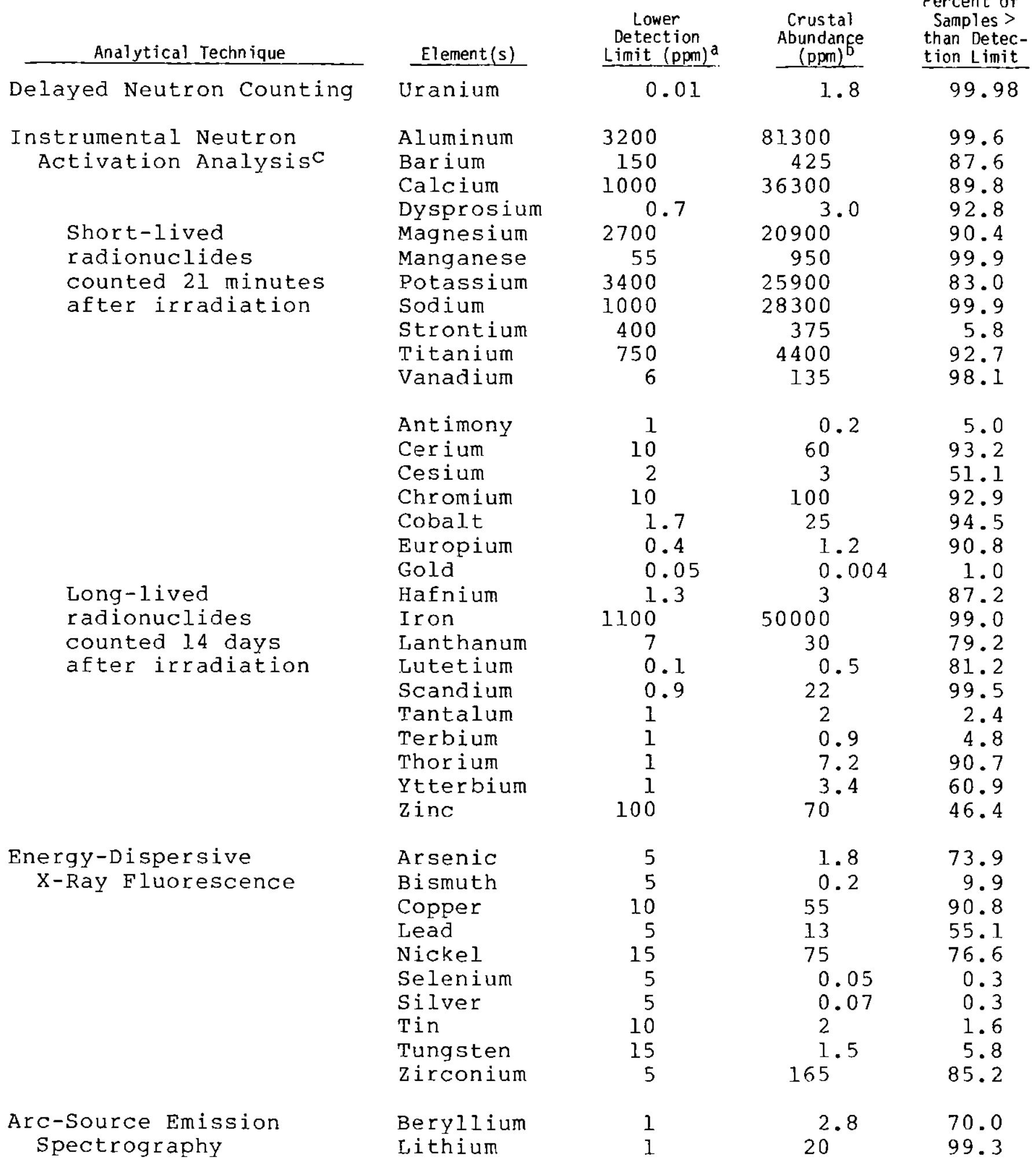

a Parts per million.
b Crustal abundances are average values from Mason (1966), p. 45-46. $c$ The lower detection limits for INAA are a complex function of sample composition and weight. Here, th average values calculated from typical $4-g$ samples (Minor et al., these elements). Because of the low number of samples having selenium concentrations above the detection limit, the arsenic or zirconium analyses were be consulted to identify the areas for which selenium led to the elimination of the emission spectrography line and resulted in the loss of lithium and beryllium data for the remainder of the program conly 15,660 samples were analyzed by this method) Because termination of lithium and beryllium analyses, the statewide coverage of these elements is less complete than for most other elements in the atlas. In addition to the elements listed in Table $I$, the samples were also analyzed for cadmium, chlorine, niobium, rubidium, and samarium, but the resulting data were not of sufficient quality detection limits that were too high (the analytical systems had not ( which resulted in sparse data, much of which was near the detection limit where the analytical errors are at a maximum. Table I still includes 11 elements for dance. These elements (antimony, arsenic, bismuth, gold, selenium, ither because they are economic in their own right or are important for environmental studies.

Uranium Determination by Delayed-Neutron Counting. Al1 sediment samples were analyzed for total uranium by DNC. A split of each sample was transferced to a clean 4-me rabbit, weighed, and the priate sample location number. The rabbits were then loaded into a 50-sample transfer clip. The reactor pneumatic transfer system and background radiation levels were checked, and standards were run for calibration. The transfer clip was installed in the transfer line
and the samples cycled through the system. A $20-$ s irradiation, 10-s and the samples cycled through the system. A $20-5$ irradiation, 10-s delay, and a $30-5$ count was used. The uranium concentration was into a data base. Above the 1-ppm level, the uranium values in sediment samples have a one-sigma error of less than $4 \%$. The specially designed delayed-neutron detectors, built by Los Alamos and used for these analyses, are described by Balestrini et al. (1976).

Elemental Determinations by Instrumental Neutron Activation A-mesediment splits were entered into the INAA sequence. Concentrations of 27 additional elements were determined by this procedure
(Table I). The full DNC/INAA timing sequence used for each sample was: 20-s irradiation, $10-5$ delay, $30-\mathrm{s}$ DNC analysis, $20-\mathrm{min}$ delay, for $96 \mathrm{~s}$, a delay for 14 days, and then a 1000 -s gamma-ray count for long-lived radionuclides. Gamma-ray counting was done by leadshielded Ge(Li) detectors; 4096-channels of gamma-ray data were recorded and later interpreted for each individual element by computer. Elemental concentrations for each sample were printed out automatically, along with their associated statistical errors. Conwere considered below the detection limit of the system and marked as such. The lower detection limit for each element in INAA is a complex function of the total composition and mass of the individual sample. Therefore, the lower detection limits in Table I are average values calculated on the basis of typical 4-g samples (Minor et al.', 1982). At concentration values exceeding one order of magnitude sample, the relative errors were generally less than $10 \%$. The INAA system used at Los Alamos is described by Garcia et al. (1982) and Minor et al., (1982).

$\frac{\text { Elemental Determinations using Energy-Dispersive X-Ray Fluores- }}{\text { A computer-controlled, energy-dispersive }}$ cence. A computer-controlled, energy-dispersive $x$-ray fluocescence system was used to determine elemental concentrations of copper, lead, nickel, silver, tin, and tungsten andiun the latter portion of of an automatic 20-position sample changer, a lithium-drifted silicon detector, a pulsed, molybdenum-transmission-target $x$-ray tube, $a$
multichannel analyzer, and a minicomputer. The sediment samples were

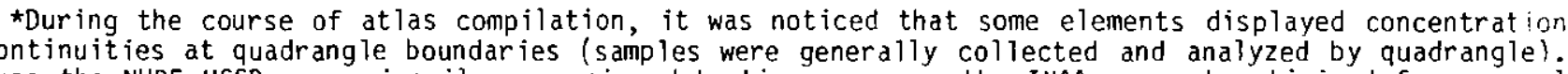
Because the NURE HSSR was primarily a urranium detection program, the INAA was not optimized for severai
of the trace elements, al though it could have been forst seven quadrangles to have magnesium concentrat ions approximately $30 \%$ greater than actual. In
order to characterize the observed discontinuities, several rearesentative sampos from the quadrangles

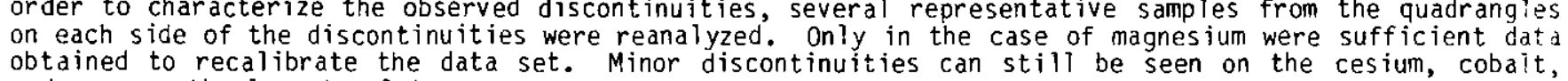


prepared for analysis by grinding 69 of each sample to a minus-325mesh powder. A computer positioned the $6-g$ samples in the $x-r$ ay mined the peak intensities for each element and calculated the ratio of the intensity of each peak to that of the molybdenum $\mathrm{K}$ (alpha) Compton peak. Concentrations of each element were then calculated using equations obtained by analyzing prepared standards. The relative standard deviation is $10 z$ or less at the $100-\mathrm{ppm}$ level and
$20 \%$ or less at the $20-\mathrm{ppm}$ level for each element. Details of the methods and equipment are described by Hansel and Martell (1977).

Beryllium and Lithium Determinations by Arc-Source Emission Spectrography. A 5 -mg portion of the minus-325-mesh sample already analyzed by $x$-ray fluorescence was mixed with 10 mg of a buffer of
one part graphite and one part spectroscopically pure $\mathrm{SiO}_{2}$. This mixture was placed into a graphite electrode that was used as the then $17 \mathrm{~A}$ for $50 \mathrm{~s}$. Photomultiplier tubes in a direct-reading spectrograph were used to measure the second order $313.0-\mathrm{nm}$ line of beryllium, the first order $670.7-$ and $610.3-\mathrm{nm}$ lines of lithium, line of vanadium. The first order 670.7-nm lithium line was used for line of vanadium. The first order $670.7-\mathrm{nm}$ lithium line was used for
lithium concentrations up to $10 \mathrm{ppm}$ and the 610.3-nm line of lithium was used for concentrations above $10 \mathrm{ppm}$. The vanadium line was used to correct the beryllium value when measurable quantities of vanadium were present. Output signals from the photomultiplier tubes were read by a digital voltmeter and processed by a desk-top calculator. Results were simultaneously printed on paper and written on cassette tape for later transmission to a compum data file. etol elenental spectra based on the results of previously run standards. precision previously run standards. proth elements and improved to $25 \%$ at concentration values greater than one order of magnitude above the lower limit.

\section{Data Analysis}

The Los Alamos Geochemistry Group has produced the Alaskan geochemical data as images to make these data available to more users. Analytical and location data for all sediment samples from Alaska were combined into elemental data bases for processing and interpre-
tation. Both statistical analyses and visual projection of element tation. Both statistical analyses and visual projection of element statistics to indicate population distributions of the elements and visual projection to display the spatial distributions. Mean, median, minimum, maximum, and cumulative frequency of concentration values greater than the detection limit were determined for each element.
The data for each element were statistically interpolated to a regular grid. Estimates of average elemental concentration values is compatible with standard image-processing and display techniques.

Data Processing. Universal kriging was the technique used to interpolate the data to a $5-\mathrm{km} \times 5-\mathrm{km}$ grid. Statistical theory of kriging assumes that the concentration values of a sample are related to or influenced by the corresponding values of surrounding samples ferea as a function of distance for each element. A variogram, a plot of semivariance vs distance, was used to determine the distance over which concentrations were interdependent and to determine a function that approximated the relation. Smoothing algorithms used that
function to determe a weighted average value for each grid cell.
The smoothing algorithms were restricted to averaging only data The smothing algorithms were restricted to averaging only data the center of the cell. Five elements (gold, selenium, silver, tin, and tungsten) had so many locations having concentrations below detection limit that a function could not be estimated. For these elements, values above the detection limit that fell within the grid
cell were averaged, with no consideration given to the values in adjacent cells.

Data Display. Two types of visual displays were used to project the geochemical data: a color-contour image, which shows the spatial image, which projects the spatial correlations of three elements simultaneously. The majority of the displays in this atlas are of illustrate the dynamic range and subtleties inherent in the data.

The color-contour image projects the value range for the data in each grid cell as a color. Nine contour levels were used corresponding to percentile ranges of concentration values greater than the
detection limit as determined from the statewide statistics of the sample data for each element. The colors and associated percentile ranges used* are:

$\begin{array}{ll}\text { dark blue } & \text { <loth percentile } \\ \text { blue-green } & \text { loth }-20 \text { th } \\ \text { light green } & 21 s t-40 \text { th } \\ \text { green } & 41 s t-60 \text { th } \\ \text { gold } & 61 s t-80 \text { th } \\ \text { yellow } & 81 s t-90 \text { th } \\ \text { pink } & 915 t-95 \text { th } \\ \text { magenta } & 96 \text { th }-99 \mathrm{th} \\ \text { red } & >99 \text { th percentile }\end{array}$

The three-element image projects each element in a different primary color (red, green, or blue). Each color has 256 levels of intensity to display concentration intervals for the element. Low as bright colors. When all three are projected simultaneously. new colors are created by the rules of color addition. The hue of the color represents the correlations or relative concentrations of the elements; intensity is a measure of the absolute concentrations. played as played as shades of yellow; red and blue correlations are displayed as shades of blue-green. If all three elements have concentrations in the same percentile ranking with respect to their individual populations, a shade of grey or white is generated. Intense white indicates a very strong correlation for the elements displayed and that each element is in one of the highest percentile levels for its the plate is displayed in red; the second, in green; and the third, in blue.

EXAMPLES OF ANALYSis AND INTERPRETATION OF ALASKAN GEOCHEMICAL

The examples described in the first subsection below demonstrate the ability to map lithologies, particularly felsic plutons, at sevdata can map a variety of major lithologies (and specific rock units) including granites, carbonates, mafic and ultramafic igneous rocks, and clastic sedimentary rocks of distinct provenance. The ability to factors. Most important, outcrops of lithologies must be areally extensive and continuous enough that the samples collected adeguately represent the unit. Lithologies having outcrop areas on the order of $10 \mathrm{~km}^{2}$ may be represented by no more than one sample in this survey. Identification of rock types having such small outcrops is unlikely, particularly using kriged data. Secondly, recognition of distinct contrast sufficiently to allow differentiation. Finally the units mental assemblages in lake sediments may be only indirect indicators of regional geochemical trends for some elements. Lake sediments have undergone a greater degree of chemical weathering and contain significant quantities of authigenic minerals and organic material that may be depleted or enriched in many elements present in the
original parent rock. Stream sediments, on the other hand, are primarily the product of mechanical weathering and represent a composite

Another way these data might be used is in mineral exploration to delineate areas favorable for more detailed investigations. Mineral deposits often occur in geochemical or metallogenic provinces interest. These provinces can be recognized becausents are generally associated with areas of widespread, low-level mineralization and tend to group into districts. The districts often cluster along specific stratigraphic or structural trends that extend over large areas. In some places, geochemical provinces can be recognized through the enrichent of elements over normal crustal values in one or more stratigraphic units within a region (e.g., Phair
and Gottfried, 1966). Related exploration targets can be suitably limited to areas within the province.

Felsic Plutons

One of the most striking examples of the use of regional gen-

*For seven elements (beryllium, bismuth, lutetium, selenium, sijver, tantalum, and terbium), the
of concentration values was very small and the percentiles listed are only approximate. 
throughout Alaska. Because of their chemistry, they stand out in marked contrast to the country rock they intrude. Not only can these among plutonic provinces are recognizable.

The felsic plutons are characterized by strong enrichment of lithophile elements such as uranium, thorium, hafnium, potassium, and rare earths. When compared to the state as a whole, these elements Elements characteristic of mafic environments, such as nickel, chromium, and cobalt, generally have very low concentrations in these areas. Among the plutonic bodies delineated by high concentrations of lithophile elements are the Coast Range batholith, Alaska-Aleutian

TABLE II

COMPARISON OF MEDIANS AND MEANS FOR SELECTED ELEMENTS IN FELSIC PLUTONS WITH STATEWIDE AVERAGES ${ }^{a}$

\begin{tabular}{|c|c|c|c|c|}
\hline \multirow[b]{2}{*}{ Element } & \multicolumn{2}{|c|}{ Felsic Plutons } & \multicolumn{2}{|c|}{ Statewide Average } \\
\hline & Mean & Median & Mean & Median \\
\hline Uranium & 7.5 & 4.2 & 3.5 & \\
\hline Thor i & 17.3 & 11.7 & 9.7 & \\
\hline Hafnium & 10.9 & 7.7 & 7.2 & \\
\hline Potassium & 16616 & 15090 & $14198^{\circ}$ & 13450 \\
\hline Cerium & 92.8 & 76.0 & 67.5 & \\
\hline Dysprosium & 6.1 & 5.0 & 5.0 & \\
\hline Lanthanum & 57.5 & 44.0 & 36.5 & 32 \\
\hline Lutetium & 0.5 & 0.4 & 0.4 & \\
\hline Nickel & 33.2 & 27.0 & 37.3 & 32.0 \\
\hline Chromium & 86.6 & 75.0 & 114.9 & 92 \\
\hline Cobalt & 17.6 & 15.2 & 18.0 & 15 \\
\hline
\end{tabular}

a All elemental averages listed as ppm.

Determined from all HSSR samples from Alaska having concentrations greater than the detection limit.

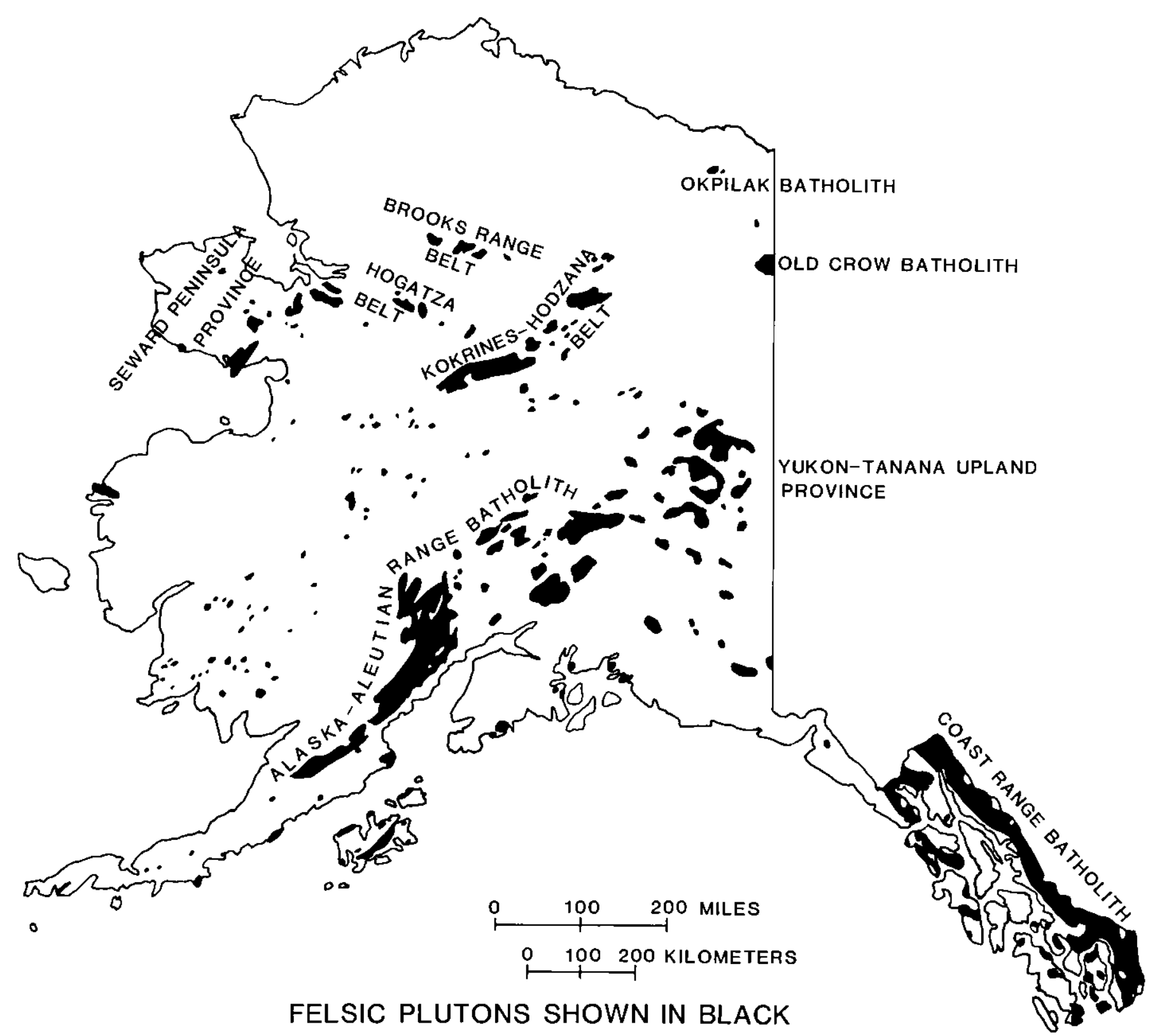

Fig. 3. Distribution of felsic plutons in Alaska (King, 1969).
Range batholith, plutons of the Seward Peninsula, the Hogatza plutonic belt, the kokr

Although the felsic plutons share many characteristics, there are subtle differences in the chemistry of plutons in different geographic settings. One of the more obvious differences is the of the coast Range and Alaska-Aleutian Range batholiths are . Rnifi cantly richer in sodium than their counterparts to the north (compare Fig. 3 with Plate 30 ). Such a pattern suggests fundamental chemical differences in the crust and/or mantle beneath these two regions or differences in their depth and history of origin.

In some places, mapping of lithologies within individual batholiths is possible using regional geochemical data. For example, Aleutian Range batholith. The southern and eastern parts of the batholith, from Becharof Lake to Talkeetna Mountains (Fig. 4), are made up primarily of diorite and quartz diorite of Jurassic age (Reed and Lanphere, 1969, 1972, and 1973 a,b). The western and northern pranodiorite of two ages, late Cretaceous-early Tertiary and midale Tertiary. Geochemical data in this atlas illustrate well the fundamental geochemical differences between the intermediate rocks of Jurassic age and the more silicic rocks of the later two magmatic epochs. Enrichment of iron, calcium, manganese, and scandium, which Jurassic liutonic a relatively chafic envium thorium, hafnices, the rare plorths, which commonly indicate a more silicic environment, and enriched in the late Cretaceous-early Tertiary and middle Tertiary

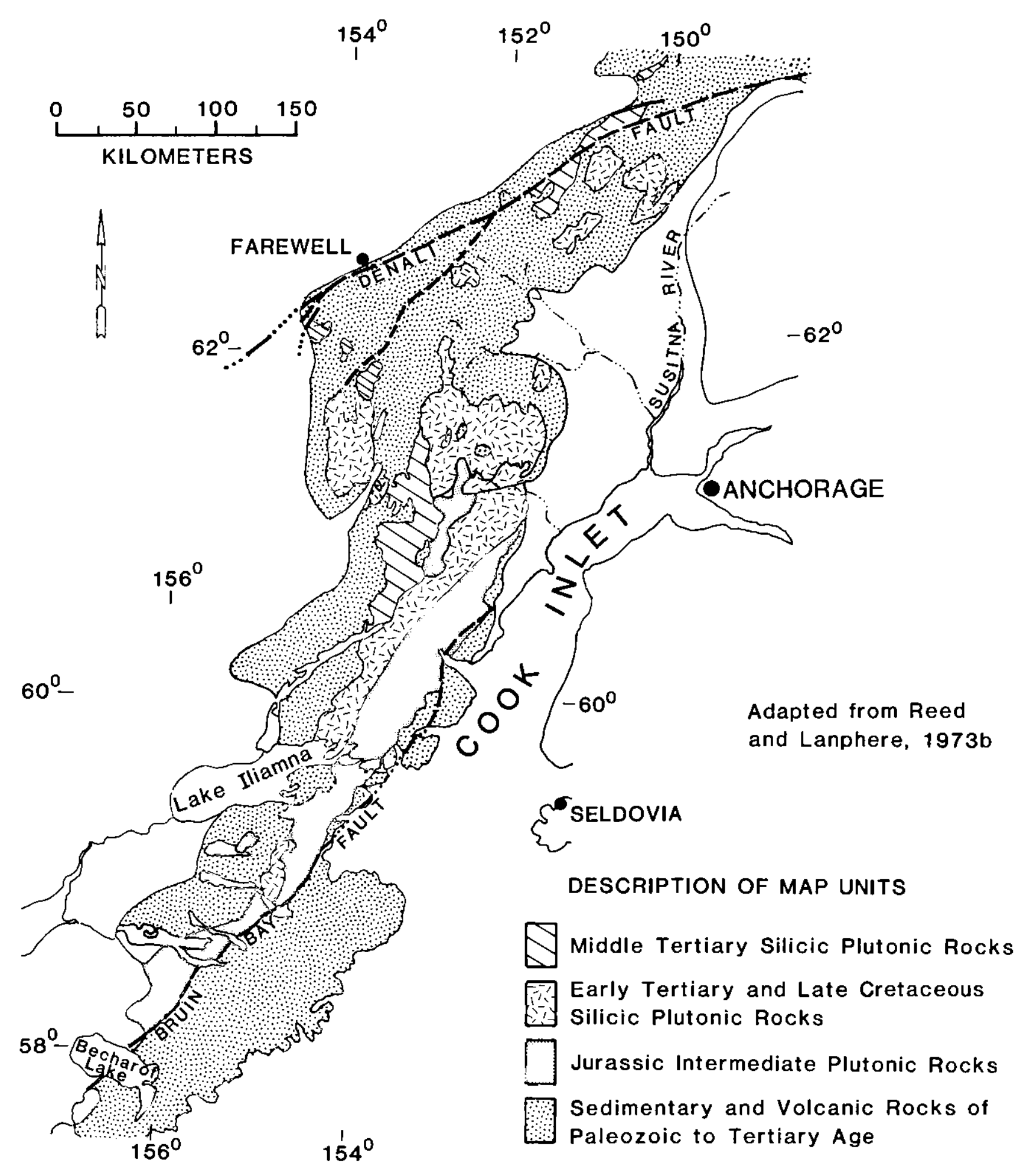
Fig. 4. Generalized geologic map of the Alaska-Aleutian Range 
rocks of the batholith. Although well exposed, the batholith is in
a remote area where high costs and poor access have limited detailed geologic investere high costs and poor access have limited detailed and chemical analyses have delineated the major geologic features of the batholith (Reed and Lanphere, 1969, 1972, and 1973 a,b). For
most areas of the batholith, geologic data are sparse and tentative coologic control exists or the systenatic and acatlly conple where chemical data presented in this atlas, when used in conjunction with the geologic data of earlier investigations, may aid the delineation of major geologic units over little-studied areas of the batholith

\section{Utilizing Geochemical Data to Identify Areas of Potential}

Whereas the primary correlation is most often between geochemistry and geology (specifically lithology), a correlation between mineral terranes depicted by AEIDC (Arctic Environmental Information and Data Center, 1979) can be seen on many of the elemental plates included in this atlas. In addition, the Brooks Range mineral belt, described by Marsh and Cathrall (1981), correlates well with anomalous concentrations of several elements. Because there are many ponding suite of anomalous elemental concentrations, we will describe ponding suite of anomalous elemental concent
the correlations observed for only a few.

Mineralized terranes typically are associated with elevated concentrations of one or more elements with respect to the regional background. Dispersion haloes commonly form around the areas of most various processes that affect the constitution of the sample, such as mixing with unmineralized material, geochemical alteration, and rate of sediment transport (mechanical effects). To look for a particular where the concentrations are the highest. Usually economic elements are found in association with other elements. Hawkes and Webb (1962), Levinson (1974 and 1980), Boyle (1974), and Mason (1966) discuss the for the the selected element to identify areas for further analysis. Threeelement plates provide a rapid visual correlation capability. To highlight the strongest correlations among three elements, a statisand 48 are the three-element plots for chromium-copper-nickel, bariumcopper-nickel, and uranium-thorium-hafnium, respectively, dividing a) of the data for each element into 256 color levels representing 256 concentration intervals. Plates 45,47 , and 49 contain the same standard ent combinations, but only concentrations greater than one displayed) in 256 color intervals.

The chromium-copper-nickel and barium-copper-nickel plates Two major trends can be regions have extensive occurrences of base-metal mineralization. It is interesting to note the changes that occur when one element is exchanged in the three-element combination--in this case, chromium barium-copper-nickel plates and mafic/ultramafic terranes correlate the region from precious metals and several ultramafic terranes (AEIDC, 1979). These four plates (44-47) not only delineate the base-metal and mafic/ where these terranes have not been mapped. Another interesting observation is that the chromium concentrations are highest, and apparently uncorrelated with copper and nickel, in the central North Slope, south of Barrow. These high North slope chromium values are found have their provenance in the Brooks rocks in which they which contains major outcrops of ultramafic rocks.

The Brooks Range mineral belt was characterized by Marsh and Marvey and Cathrall, the belt is a structuraly. As described by central metamorphic belt and adjacent metasedimentary units, extending from $147^{\circ} \mathrm{W}$ to $159^{\circ} \mathrm{W}$ and $67^{\circ} \mathrm{N}$ to $69^{\circ} \mathrm{N}$. Their studies identified molybdenum suite of molybdenum-tin-tungsten--which suggests several types of mineralization in the mineral belt. The data in this atlas show elevated concentrations of these elements with respect to statewide averages in the mineral belt, with the exception of molybdenum, other elements, (e.g., arsenic, iron, manganese, nickel, and uranium: have higher than average concentrations in this zone. The threeand their corresponding greater than one standard deviation above the mean plates show the belt as two flank of the Brooks Range. These lines extend almost continuously from 148 W to 159 $W$ and map the extent of the central metamorphic belt. A detailed examination (done previously on the raw sample datas of mineralization in the belt: (1) within Cretaceous, granitic plutons that intrude the metamorphic rocks; (2) at the contacts of these plutons and the metamorphic rocks; and (3) in metavolcanic rocks of the belt and not associated with the plutons. Portions of the Brooks Range mineral belt are also identified as mineral terranes the AEIDC (1979) maps.

The examples above describe the correlation between the geomight be used to direct a reconnaissance exploration program.

Mineral deposits form in association with felsic plutonic rocks when the proper combination of source rock, host rock, structural porphyry systems). In some cases, the source of anomalous metals can be associated with unusual enrichments of major and/or trace elements within the plutons themselves (e.g. the association of uranium deposits with peralkaline granites at Bokan Mountain and the anomalous thorium, and cesium, In cases where the chemistry of the plutons is an important factor in controlling the formation of mineral deposits, the data presented in this atlas may be useful in distinguishing potential mineralized plutons from their barren companions.

One case in which this approach could be applied is the evaluation of uranium potential in felsic plutons. These plutons can be ium deposits or as potential source rocks for stratabound uranium deposits. Using enrichment of elements such as uranium, rare earths, hafnium, and potassium as criteria for favorability, some plutons such as the intermediate-composition Jurassic rocks of the AlaskaAleutian Range batholith, and many of the plutons in the Yukon-Tanana Upland province can be eliminated from consideration (Fig. 3 and
plate 49). For the remaining felsic plutons, favorability criteria can be based on models for the formation of uranium deposits. For example, ratios of uranium/thorium, uranium/hafnium, and uranium/rare earth elements can be used to characterize the availability of mobile uranium for transport and concentration into deposits. In theory, rer high original uranium endowment. Low ratios signify that the uranium is tied up in an immobile form in accessory minerals such as monazite, allanite, and zircon, which are relatively impervious to dissolution. Examination of Plate 39 shows that large areas of the protonic belts can be eliminated from consideration in an exploration program (note particularly the extremely low U/Th found in the region areas of particularly high ratios.

Another approach is to establish favorability criteria based on chemical characteristics of granites known to host deposits. For example, if uranium deposits occur in plutons characterized by enrichment of uranium and hafnium but depletions of thorium, the threeelement greater than one standard deviation above the mean plots,
such as those on Plate 49 , could be used to identify those plutons or areas within plutons where these characteristics occur.

\section{RECOMMENDATIONS}

1. Serious users of the Alaskan HSSR data should definitely obtain and atilize the raw digital data. For consistency, this atlas routine throughout. Further, stream- and lake-sediment data have been combined for areal completeness. Specific problems will almost certainly require some modification of any or all of these procedures. puter files. In addition, the and raw data are avallable on computer files. In addition, the geologic map of Beikman (1980) has been geolcgic plate in this atlas; these are also on a computer file at 
Los Alamos. Using the raw digital data, researchers can reformat the data, add in data of their own, interpolate using kriging or anothe included in this atlas, can be of importance for specific problems.

2. The state of Alaska should consider sampling and analyzing the samples from the portions of the state not sampled during the the sampling to the densities obtained during the HSSR. To maximize the comparability with existing data, it is further recommended that sampling and analytical procedures similar to those employed herein

3. Future analyses of geologic materials should be optimized for minor and trace elements. Although state-of-the-art methods were sarily the methods of choice for some elements. Subsequent to the HSSR analyses, the Research Reactor Group at Los Alamos has developed
a three-delay procedure for INAA that includes several additional AEIDC (Arctic Environmental Information and Data Center), 1979 ,
Mineral Terranes of Alaska, Plates A-F, University of Alaska, Anchorage.

Balestrini, S. J., Balagna, J. P., and Menlove, H. O., 1976, Two specialized delayed-neutron detector designs Methods, v. 136, pp. 521-524.
Melate

Beikman, H. M., 1980, Geologic map of Alaska, prepared by the U.S. Geological Survey in conjunction with the

Bolivar, S. L., 1980, An overview of the National Uranium Resource Evaluation Hydrogeochemical and Stream Sediment Reconnaissance program, Open-file report GJBX-220(80), US DOE, Grand Junction Colorado, 24 p.

Bolivar, S. L., 1981, The Los Alamos Scientific Laboratory approach to hydrogeochemical and stream sediment reconnaissance for uranium in $22 \mathrm{p}$.

Boyle, R. W., 1974, Elemental associations in mineral deposits an indicator elements of interest in geochemical prospecting (Revised)

Garcia, S. R., Hensley, W. K., Minor, M. M., Denton, M. M., and Fuka, M. A., 1982, An automated multidetector system for instrumental neutron activation analysis of geologic and environmental materials, in Atomic and Nuclear Methods in Fossil Energy Research, R. H. Filby, B. S. Carpente
York, pp. $133-140$.

Hansel, J. M., and Martell, C. J., 1977, Automated energy-dispersive $x-r a y$ determination of trace elements in stream sediments, Open-
file report GJBX-52(77), US ERDA, Grand Junction, Colorado, 8 p.

Hawkes, H. E. and Webb, J. S., 1962, Geochemistry in Mineral Explora-

King, P. B. (Compiler), 1969, Tectonic Map of North America, Levinson, A. A., 1974, Introduction to Exploration Geochemistry (2nd Ed.), Applied Publishing Lta., Wilmette, Illinois, 612 p.

Levinson A. A., 1980, Introduction to Exploration Geochemistry, the 1980 Supplement, Applied Publishing Ltd., Wilmette, Illinois,

Marsh, S. P., and Cathrall, J. B., 1981, Geochemical evidence for a Brooks Range mineral belt, Alaska, J. Geochem. Explor, v. 15,

Mason, B., 1966, Principles of Geochemistry (3rd Ed.), John wiley and Sons, Inc., New York, 329 p.

Minor, M. M., Hensley, W. K., Denton, M. M., and Garcia, S. R., 1982, tivation analysis system, J. Radioanal. Chem., 70, An automated elements (e.g., arsenic, bromium, gallium, tungsten) in addition to improving the detection limits for many of the INAA-detected elements in this atlas (Minor et al., 1982).

4. Researchers on such topical problems as environmental monitoring for health and safety, agricultural and livestock management, and land-use-capability studies should be made aware of the existence Alaska, these data are from samples from atlas is an example. In vironment, which can be used as a baseline against which to monitor changes.

5. Researchers interested in specific areas should not ignore information contained in the individual raw sample data. This atlas present (statistics presented 62 , All other appropriate things considered, the relative concentrations for single elements in small areas and the relative concentrations for all elements in a single sample are very important pieces of
information when looking for mineralization, etc.

National Geographic Society, 1982, America's Federal Lands, map insert to National Geographic Magazine, September 1982. Olea, R. A., 1974, Optimal contour mapping using Universal Kriging,
J.'Geophys. Res., v. 79, No. 5, pp. 695-701.

Olsen, C. E., 1977, Uranium hydrogeochemical and stream sediment pilot survey of the Estancia Valley, Bernalillo, Santa Fe, San Miguel, and Torrance Counties, New Mexico, Open-file report GJBX-21(77),
US ERDA, Grand Junction, Colorado, 31 p.

Phair, G. and Gottfried, D., 1966, The Colorado Front Range, Colorado, USA, as a uranium and thorium province, in The Natural Radiation Press, pp. 7-38.

Reed, B. L., and Lanphere, M. A., 1969, Age and chemistry of Mesozoic and Tertiary plutonic rock

Reed, B. L., and Lanphere, M. A., 1972, Generalized geologic map of the Alaska-Aleutian Range batholith showing potassium-argon ages of the
MF 372 .

Reed, B. L., and Lanphere, M. A., 1973a, A plutonic rock of the Alaska-Aleutian Range batholith, Arctic Geology, U.S. Geol. Surv. Mem. 19, pp. 421-430.

Reed, B. L., and Lanphere, M. A., 1973b, Alaska-Aleutian Range batholith: geochronology, chemistry, and relation to
plutonism, Geol. Soc. Am. Bull., v. 84, pp. 2583-2610.

Rose, A. W., Hawkes, H. E., and Webb, J. S., 1979, Geochemistry and Mineral Exploration, (2nd Ed.), Academic Press, New York, 657 p.

Sharp, R. R., Jr., 1977, The LASL approach to uranium hydrogeochemical reconnaissance, Proc. Symposium on Hydrogeochemical and Stream Sediment Reconnaissance for Uranium in the United States, Junction, Colorado, pp. 353-373.

Sharp, R. R., Jr. and Aamodt, P. L., 1978, Field procedures for the uranium Hydrogeochemical and Stream sediment Reconnaissance as used by the Los Alamos selentific Laboratory, Open-file report

Sharp, R. R., Jr., and Bolivar, S. L., 1981, One hundred prime references on hydrogeochemical and stream sediment surveying for uranium as internationally practiced, including sixty annotated references, Open-
Colorado, $89 \mathrm{p}$.

Webb, J. S., Nichol, I., Foster, R., Lowenstein, P. L., and Howarth, R. J.' 1973, Provisional geochemical atlas of Northern Ireland,
Tech. Comm. 60, Applied Geochemistry Research Group, London, 86 .

Webb, J. S., Thornton, I., Thompson, M., Howarth, R. J., an Lowenstein, P. L., 1978, The Wolfson Geochemical Atlas of Englani and Wales, Clarendon Press, Oxford, $69 \mathrm{p}$. 


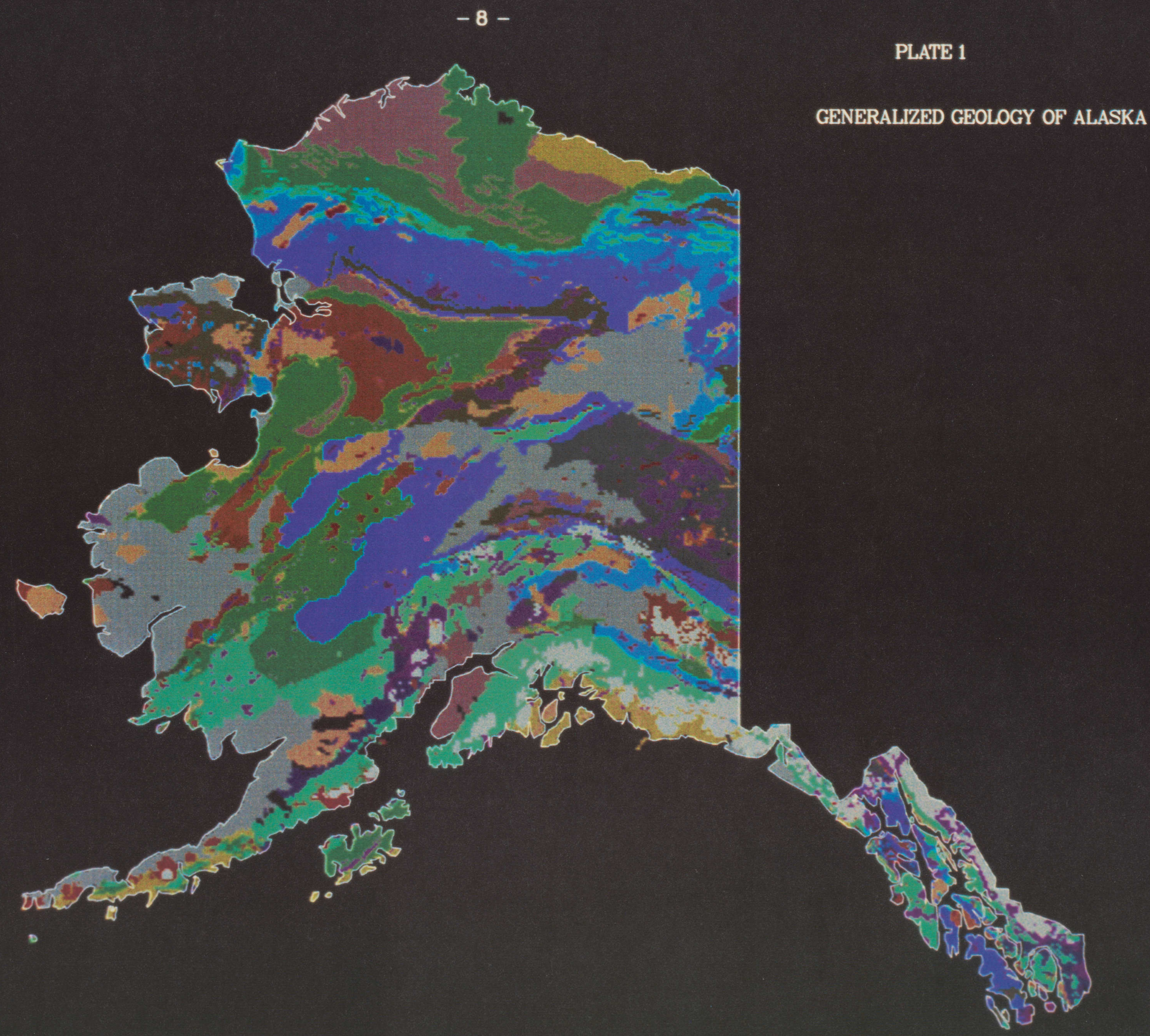


I. STRATIFIED SEDIMENTARY SEQUENCE

Quaternary Deposits. Alluvial, glacial, lake, swamp, eolian, flood plain,

Tertiary Sedimentary Rocks. Mainly marine, in part highly deformed and metamorphosed. Includes sandstone, siltstone, shale, greywacke, and locally

Tertiary and Cretaceous Continental Deposits. Sandstone, arkose, siltstone,

Upper Mesozoic Sedimentary Rocks. Mainly marine, consist of Cretaceous greywacke, sandstone, shale, siltstone with minor argilstite, conglo

Middle and Lower Mesozoic Sedimentary Rocks. Mainly rocks ranging in age from early Cretaceous to Triassic, but locally include late Paleozoic rocks. Consists of argillite, shale, greywacke, quartzite, conglomerate, lava, tuff, agglomerate, and limestone. In southern Alaska and in the Panhandle region diorite, greenschist, layered gabbro, and serpentinite in a pelitic intrix.

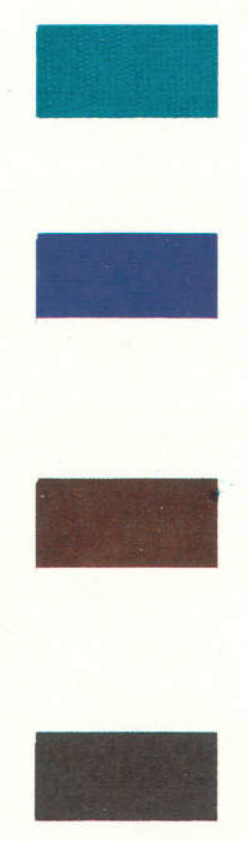

Upper Paleozoic Sedimentary Rocks. Argillite, chert, shale, siltstone, limestone, greywacke, basaltic to andesitic volcanic rocks and derivative volcaniclastic sediments. Locally metamorphosed to greenschist and amphibolite facies.

Lower Paleozoic Sedimentary Rocks. Include rocks of Cambrian through Devonian age, in places metamorphosed to greenschist and amphibolite facies. Sedimentary rocks include limestone, dolomite, argillite, chert, and greywacke. Metasedimentary rocks include schist, quartzite, slate, gneiss, greenstone, marble, and phyllite.

Upper Precambrian Rocks. Siltite, phyllite, greywacke, quartz-mica schist, and migmatite.

II. METAMORPHIC ROCKS

Mesozoic through Precambrian Metamorphic Rocks. Metasedimentary, metaplutonic and metavolcanic rocks, including phyllite, schists, and gneiss of many
compositions, primarily of blueschist, greenschist, or amphibolite facies.

III. VOLCANIC ROCKS

Felsic Volcanic Rocks. Range in age from Cretaceous through Quaternary, include rhyolites, quartz latites, and dacites.

Intermediate Volcanic Rocks. Primarily Jurassic through Quaternary in age, primarily of andesites, latites, and trachytes.

Mafic Volcanic Rocks. Paleozoic through Cenozoic in age. Consist primarily of basalts.

\section{INTRUSIVE ROCKS}

$\frac{\text { Felsic Intrusive Rocks. Paleozoic through Cenozoic granite, quartz monzonite, }}{\text { and granodiorite. }}$

Intermediate Intrusive Rocks. Paleozoic through Cenozoic diorite, monzonite, Mafic and Ultramafic Intrusive Rocks. Late Precambrian through Cenozoic in age. Consist of gabbro, peridotite, and serpentinite.
$Q h, Q, Q p$

Tp, uT, Tm, To, Te, T,

Tpc, UTc, Tmc, MTc, lTc

$\mathrm{uK}, \mathrm{K}, \mathrm{lK}$

$\mathrm{KJ}, \mathrm{KJ}_{1}, \mathrm{KJ}_{2}, \mathrm{KJ}_{3}$,
$\mathrm{uJ}, \mathrm{mJ}, 1 \mathrm{JJ}^{\prime}, \mathrm{J}, \mathrm{R}, \mathrm{RP}$

UR, JP, MzPz

D, UD, UMD, DS, S, O

So, $\epsilon$, Ope, IPz

lpzpe, $z_{1}, z_{1}, z_{2}$

IJm, Mzm, JPm, Pzm, Pzpem Qhvf, Tvf, TKve, uKvf,

Qhv, Qpv, Qv, QTv, Qhvi, Tvi, Tpv, Tmv, uTv, Txv, ITV, TV, TKV, IKVi, KVi KJvi, Jvi, $1 \mathrm{KV}, \mathrm{Kv}, \mathrm{KJ} v$
$\mathrm{Dv}, \mathrm{Ov}, \mathrm{zv}$

Qhvm, Qpvm, Qvm, QTvm, lTvm, TVm, TKVm, KJVm, Dvm, CVm, Pzvm

Tmif, Toif, Teif, Txif,
Tif, TKif, TMzif, Ti, TK Tif, TKif, TMzif, Ti, TKi Mzif, Mzi, MzPzi, MzPzif TPi, Tif, upzif, Oi, Pzi, lPzpei, Pzpei, if, i

mTi, Tii, TKii, UKii, Mzí, MzPzii, Sii, Pzí

Tmim, mTim, Tim, TKim, TMzim, Kim, Jim, Mzim, Pzim, lpim, upzim, lPzim Ku, Mzu, JPu, MzPzu, Ou, lPzu, Pzu, u 


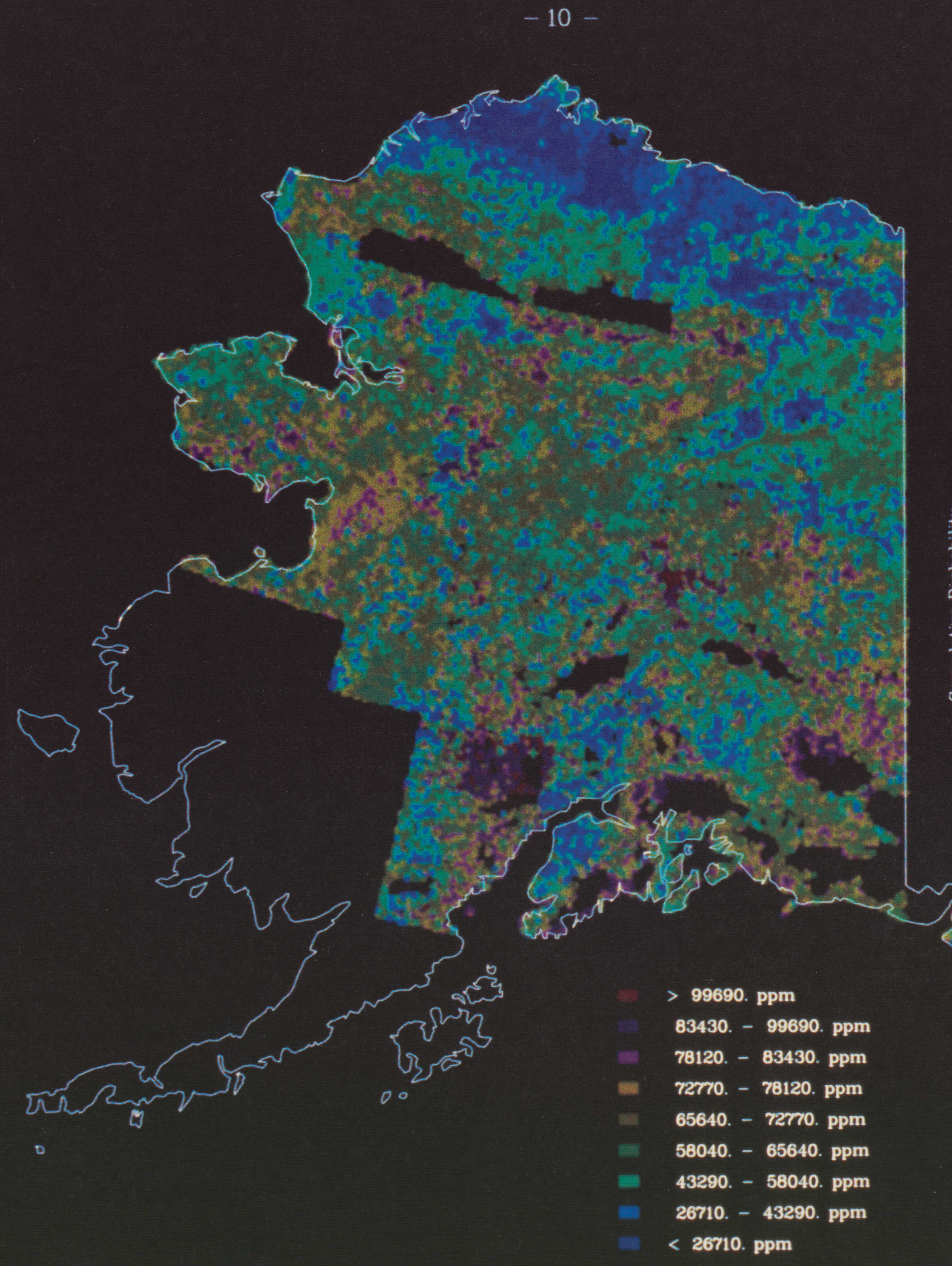

PLATE 2

ALUMINUM

For 61643 Values above Detection Limit

Mean

Minimum

Median

Maximum

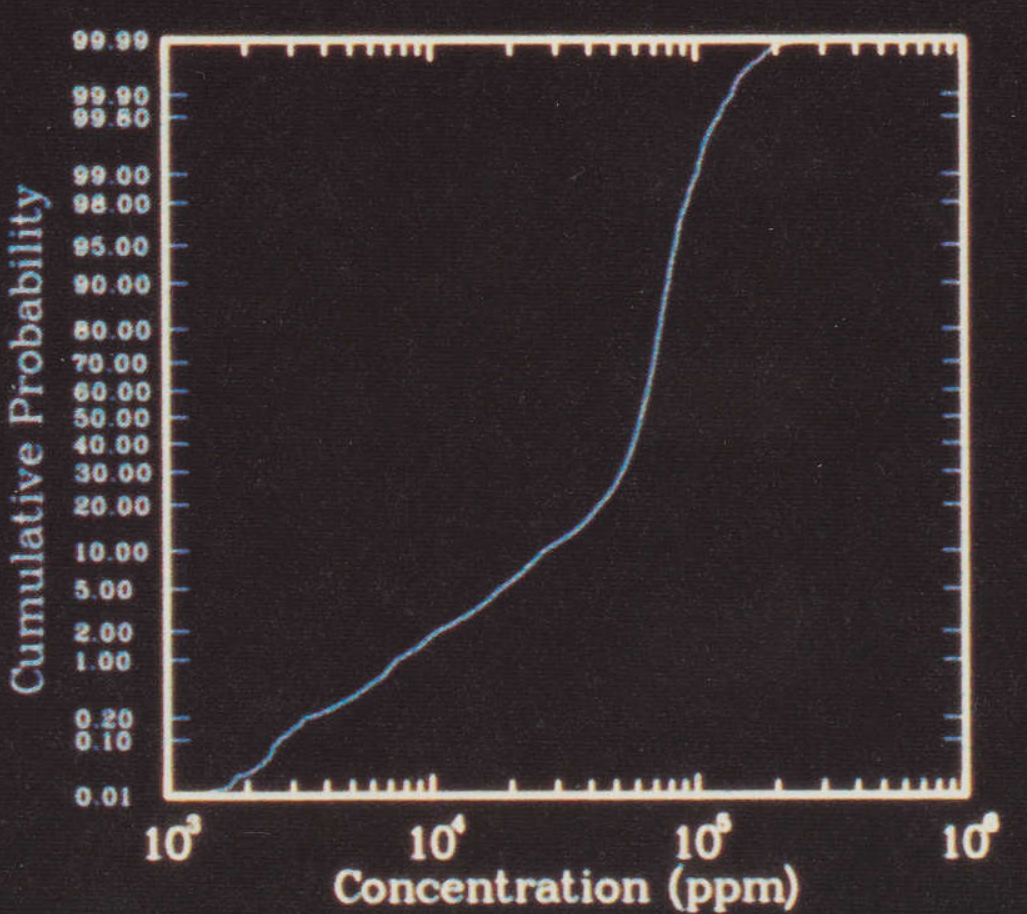

$58178.83 \mathrm{ppm}$

$1017.00 \mathrm{ppm}$

$62090.00 \mathrm{ppm}$

$815620.00 \mathrm{ppm}$

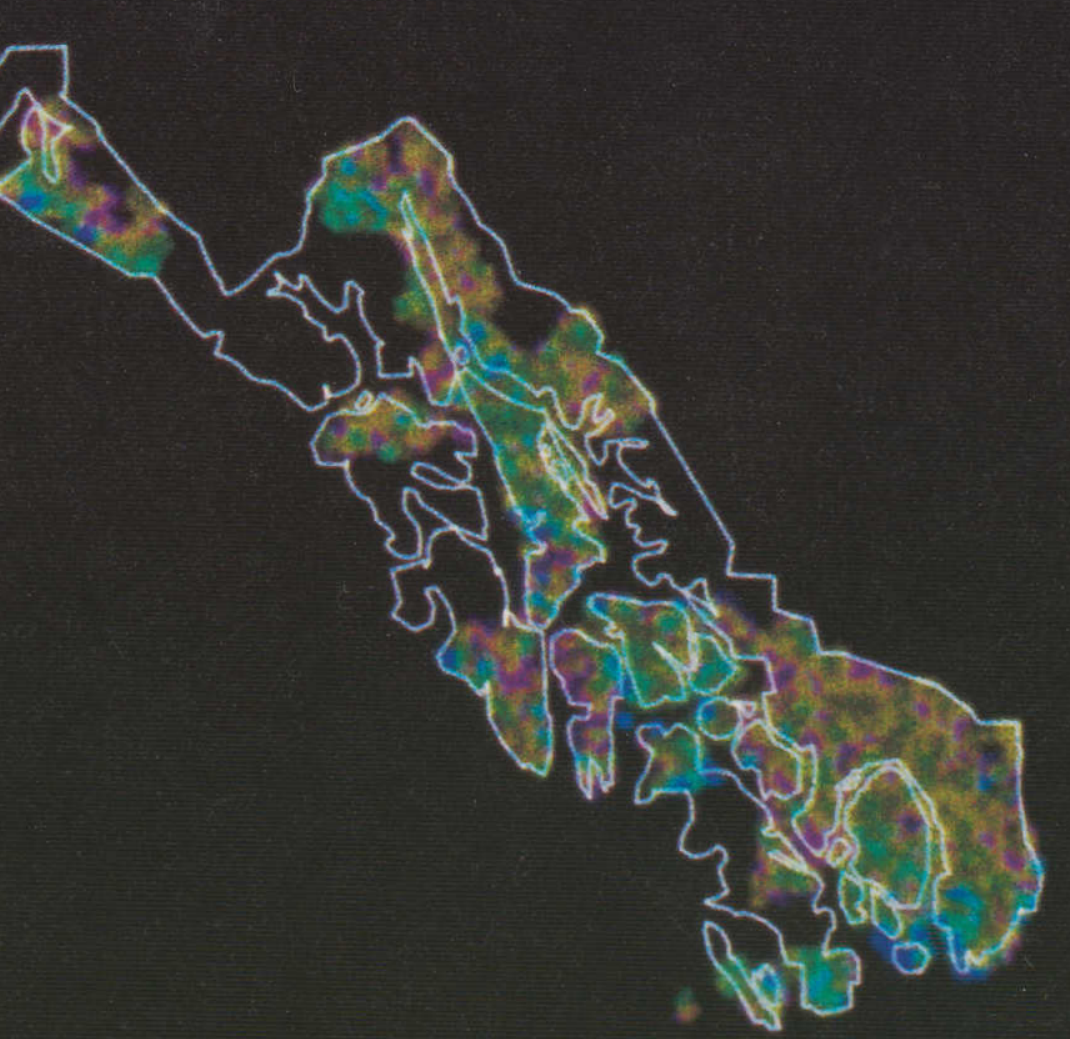




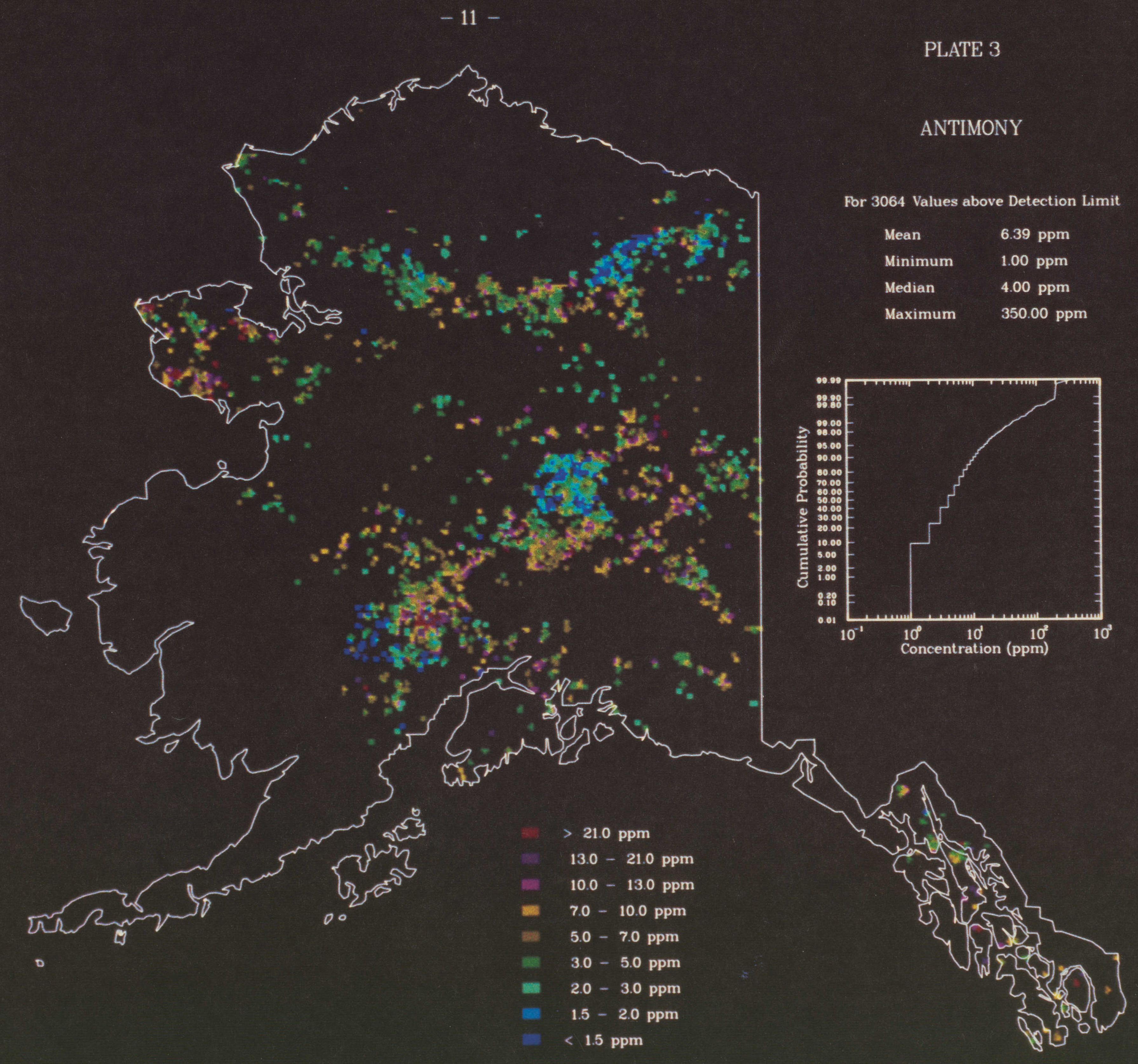




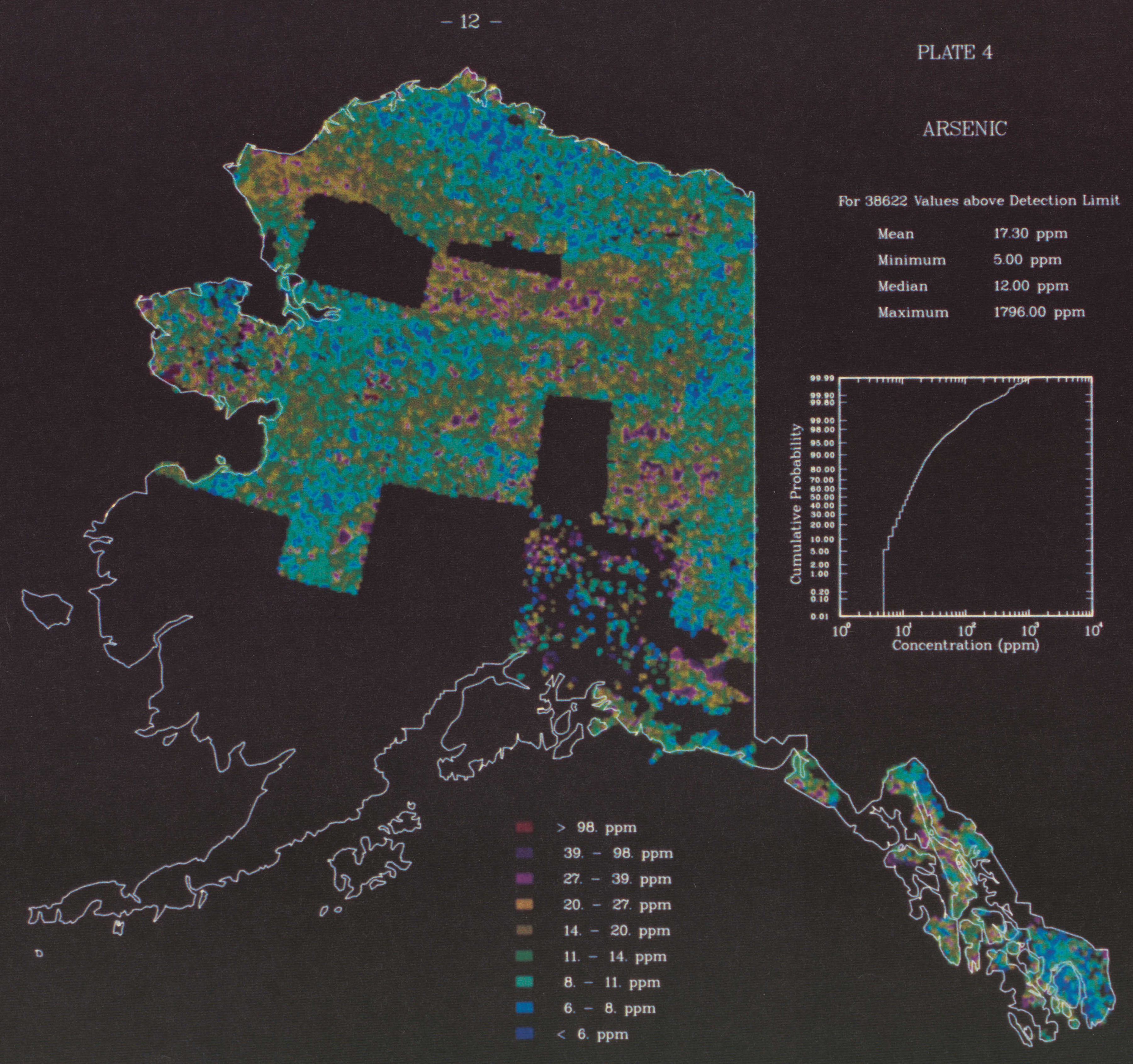




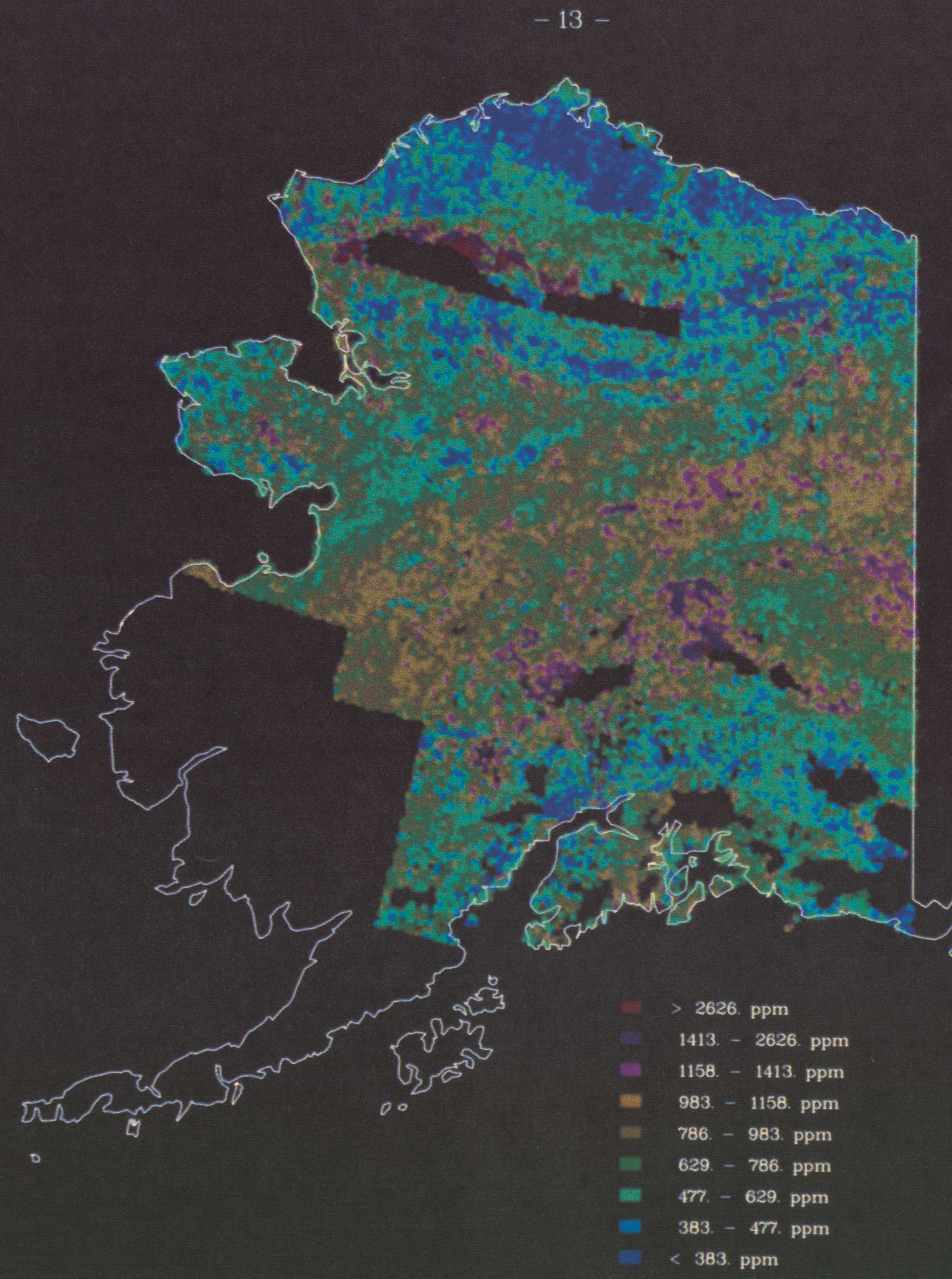

PLATE 5

\section{BARIUM}

For 54272 Values above Detection Limit

Mean

Minimum

Median

Maximum

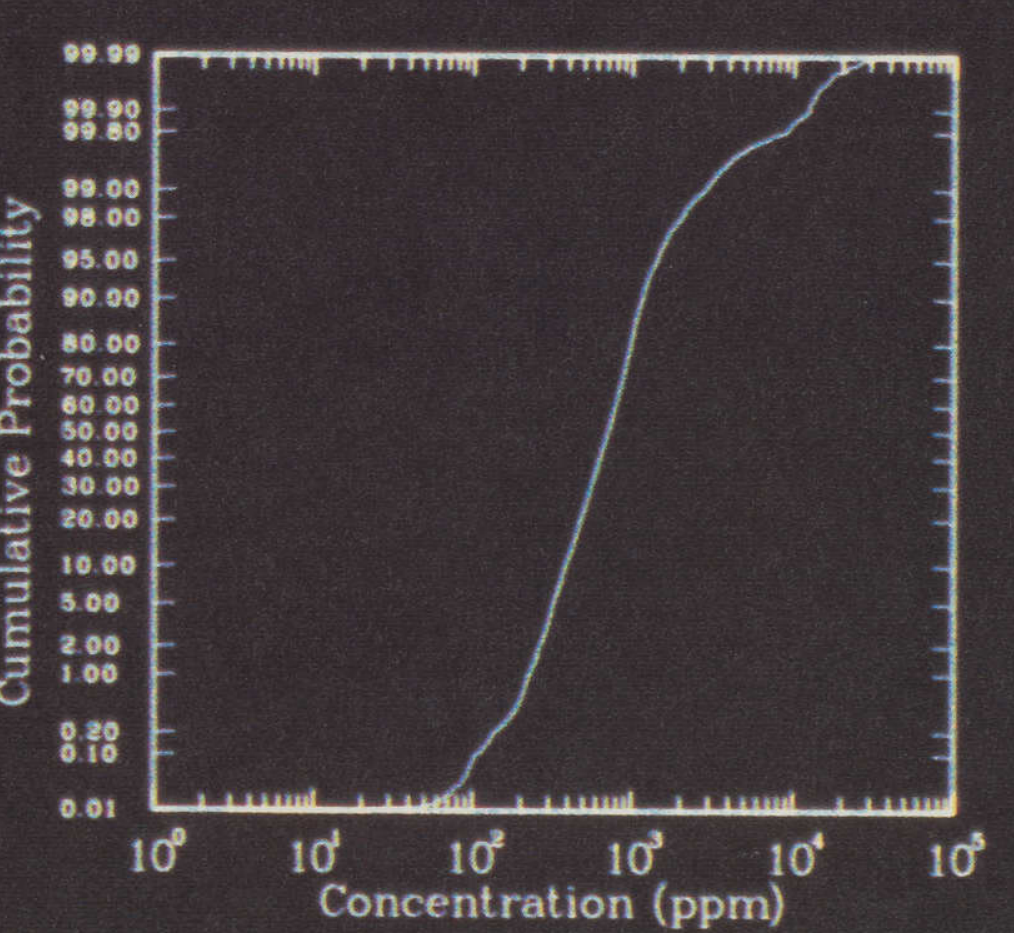

$0.98 \mathrm{ppm}$

$3.00 \mathrm{ppm}$

$707.00 \mathrm{ppm}$

$64350.00 \mathrm{ppm}$ 
$-14-$

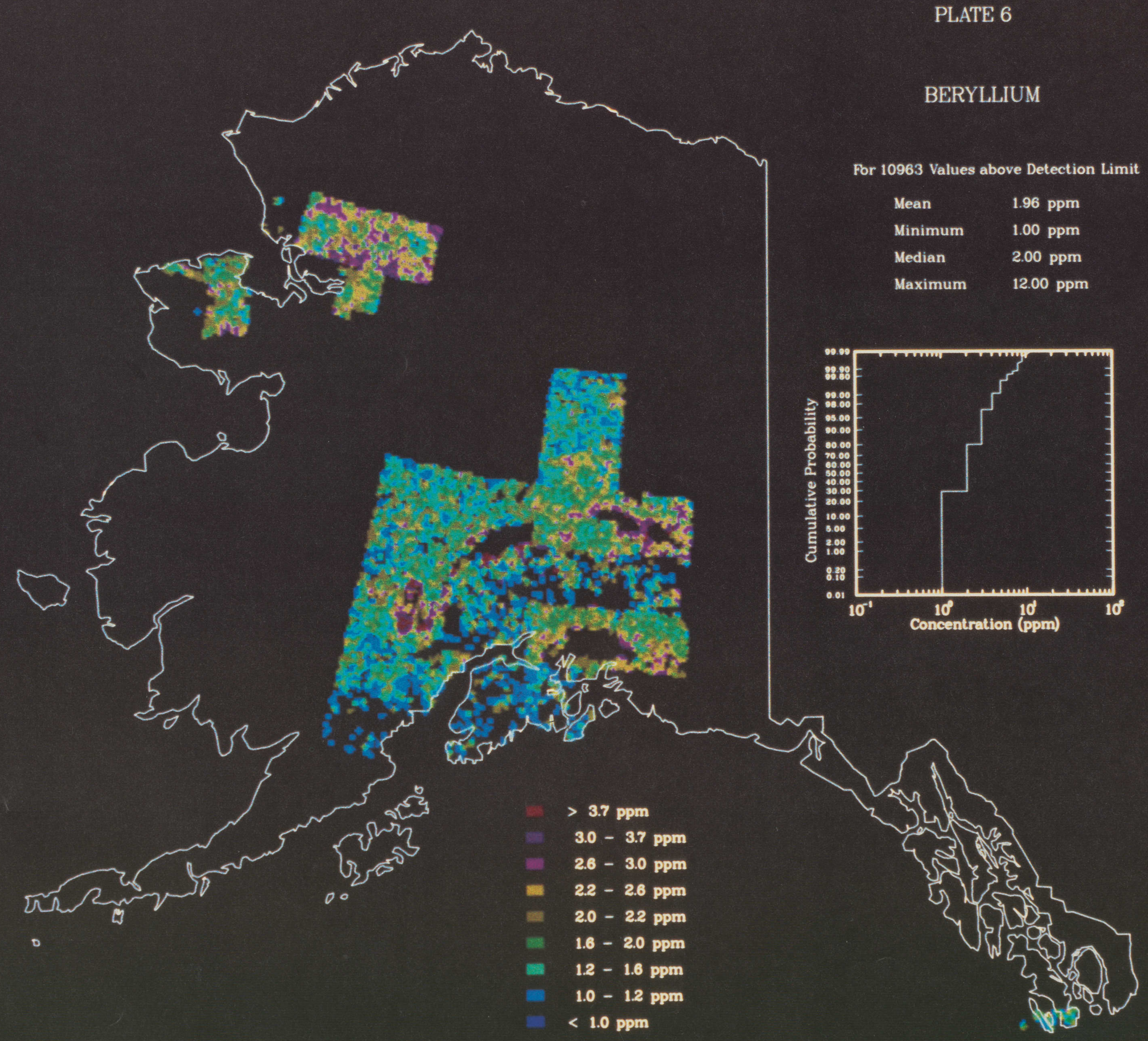


$-15-$

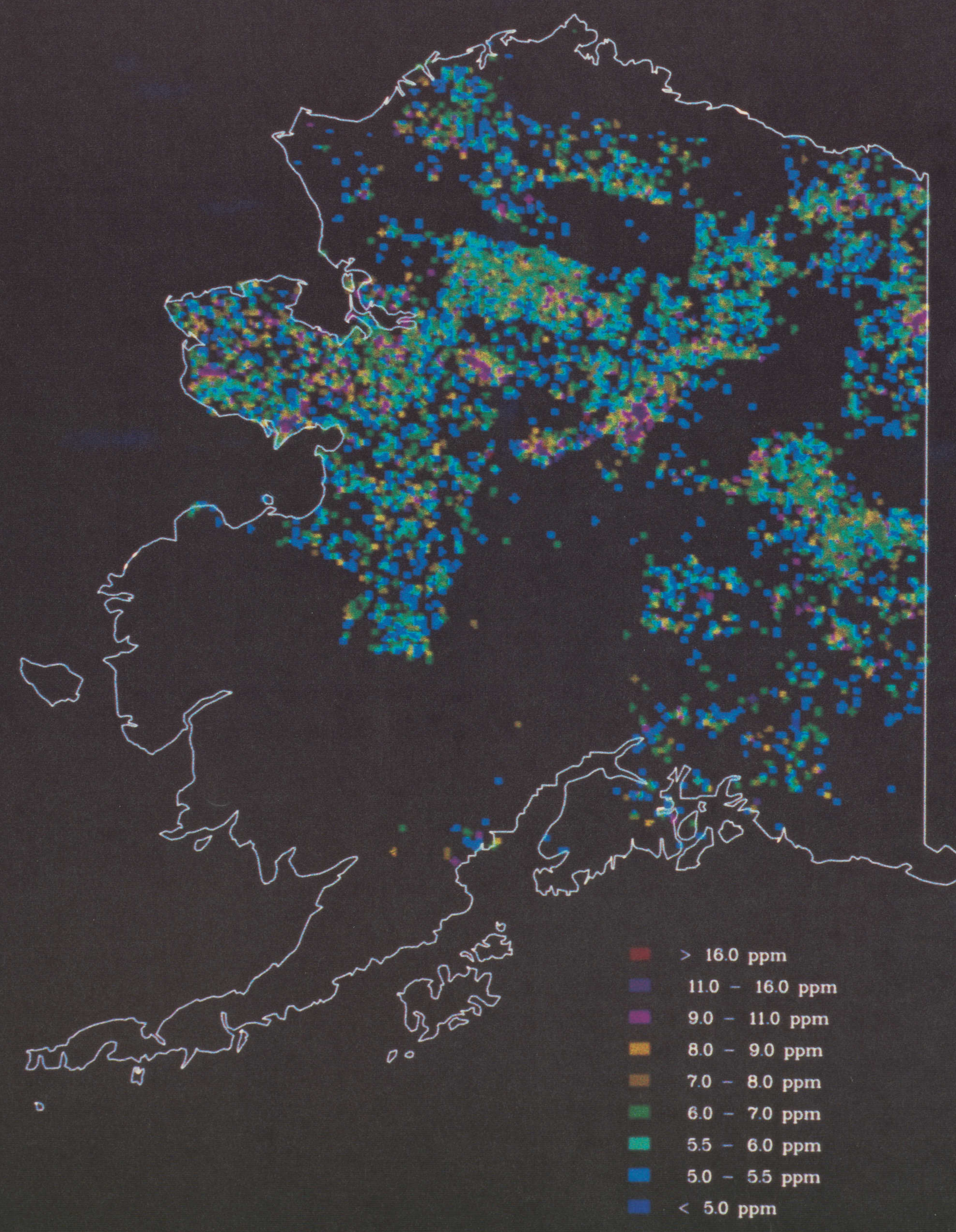

PLATE 7

BISMUTH

For 6100 Values above Detection Limit

$\begin{array}{ll}\text { Mean } & 6.64 \mathrm{ppm} \\ \text { Minimum } & 4.00 \mathrm{ppm} \\ \text { Median } & 6.00 \mathrm{ppm} \\ \text { Maximum } & 51.00 \mathrm{ppm}\end{array}$
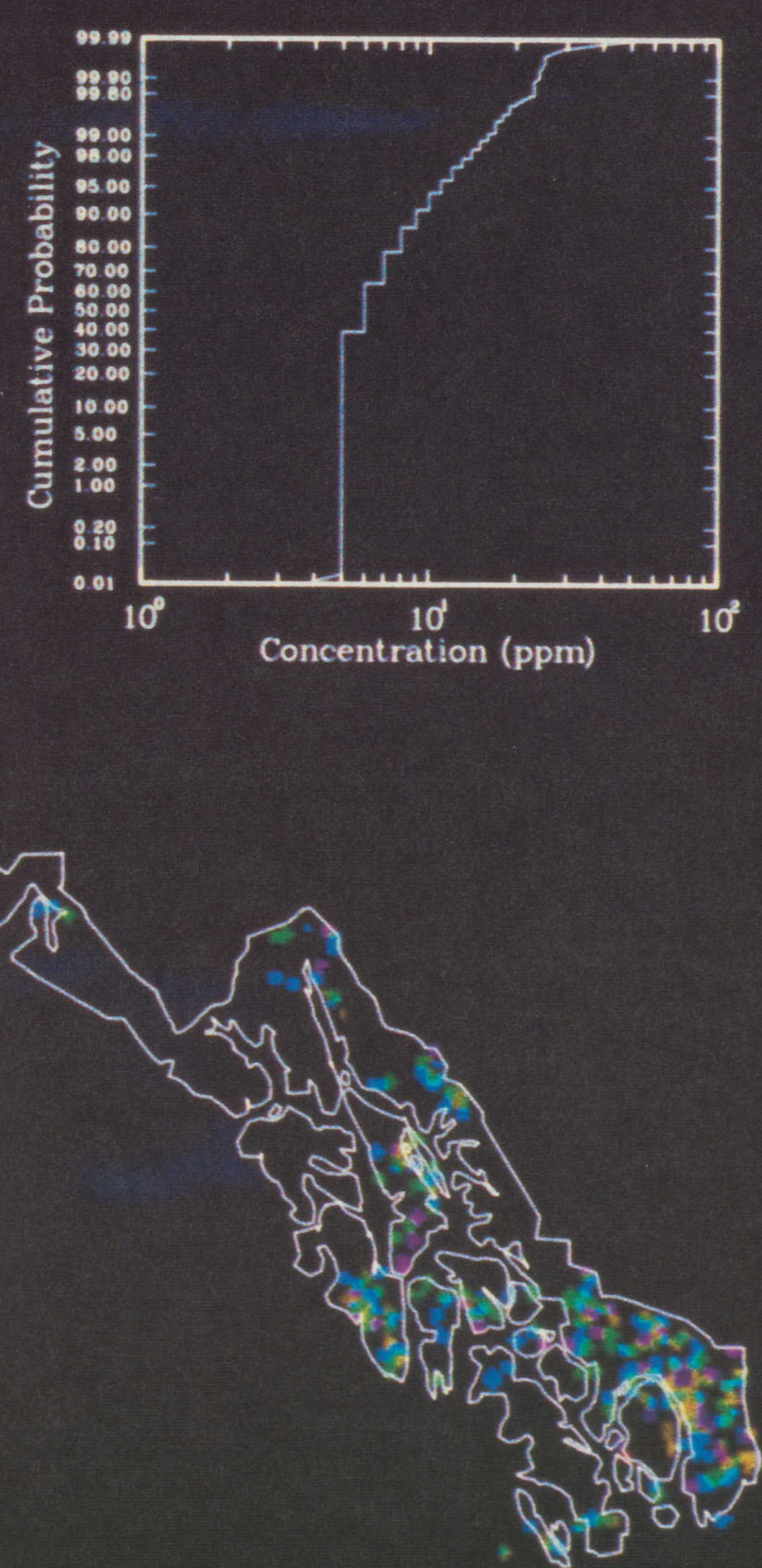
$-16-$

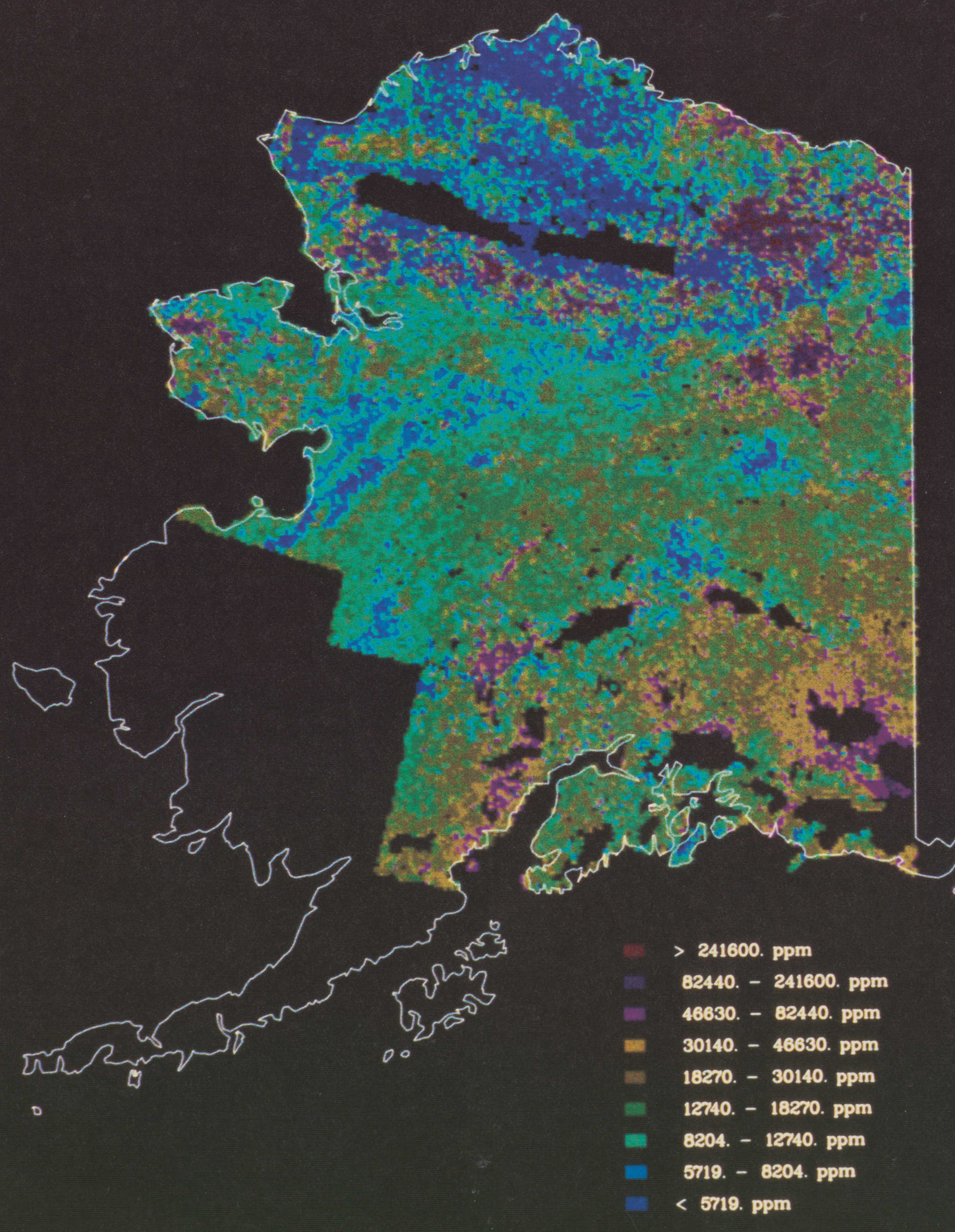

PLATE 8

CALCIUM

For 55637 Values above Detection Limit

Mean $26449.02 \mathrm{ppm}$

Minimum $\quad 411.00 \mathrm{ppm}$

Median $\quad 15320.00 \mathrm{ppm}$

Maximum $\quad 407900.00 \mathrm{ppm}$

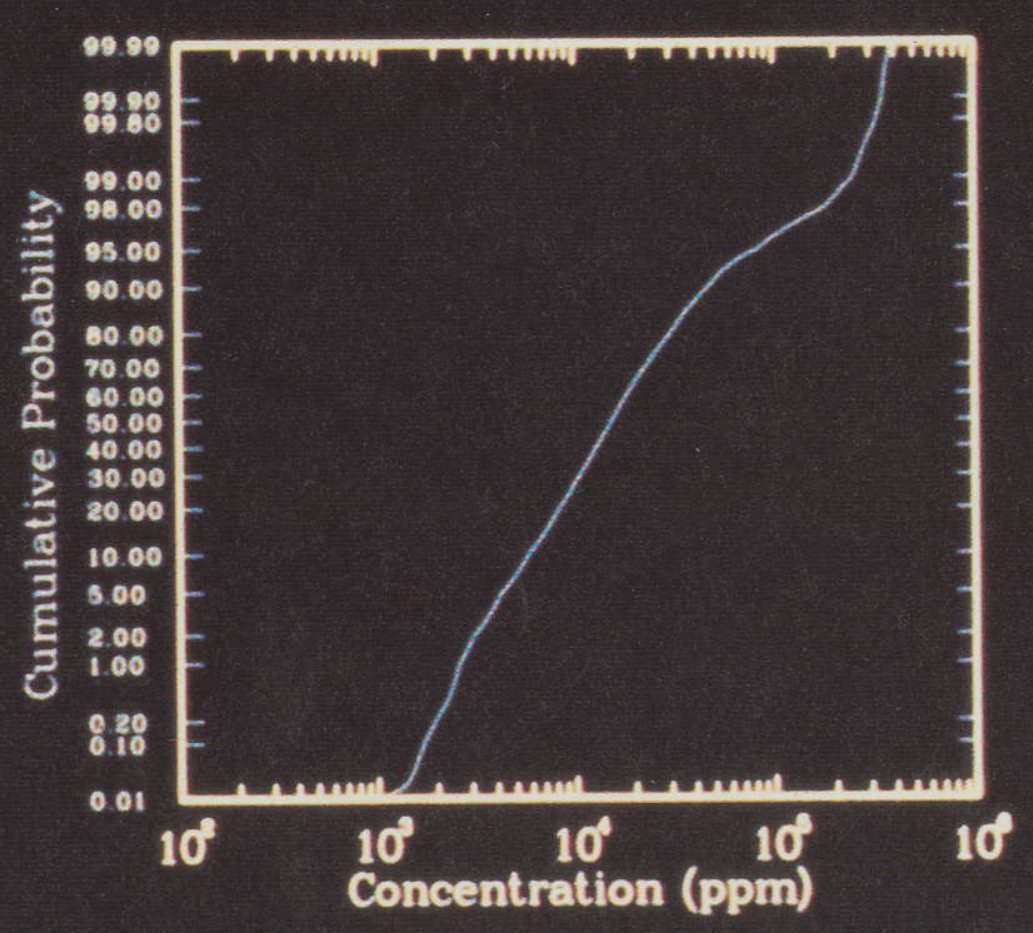




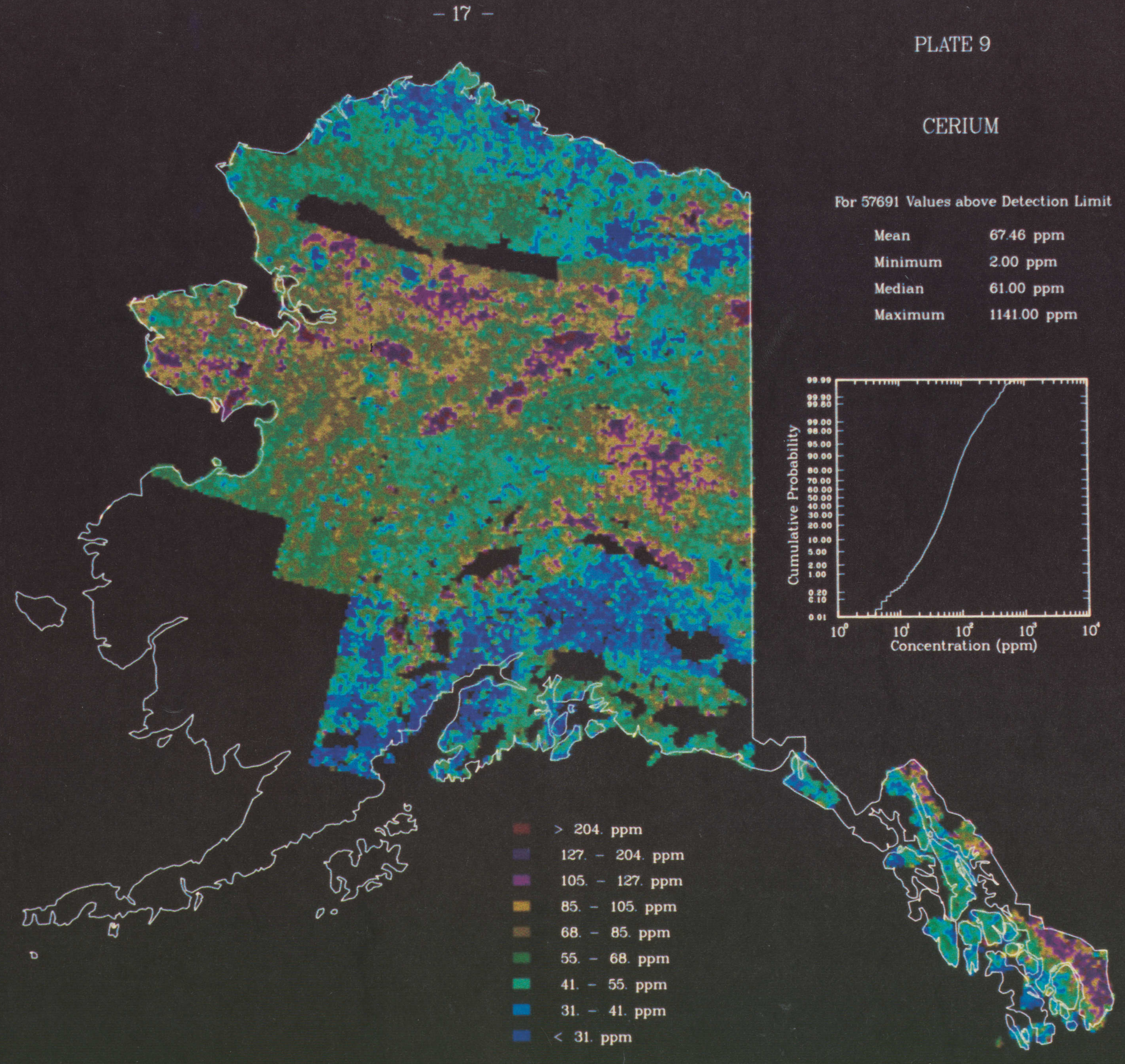




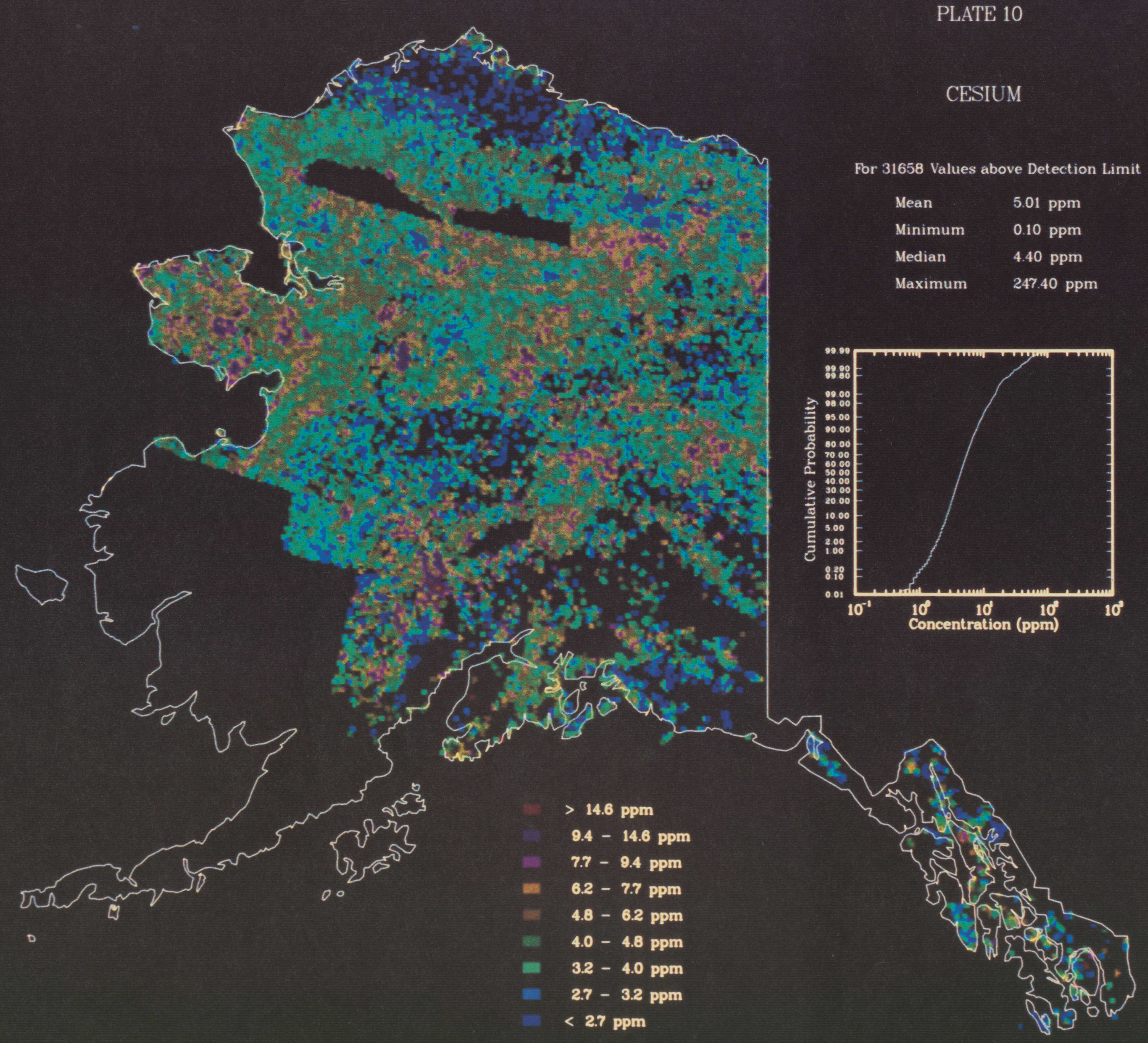




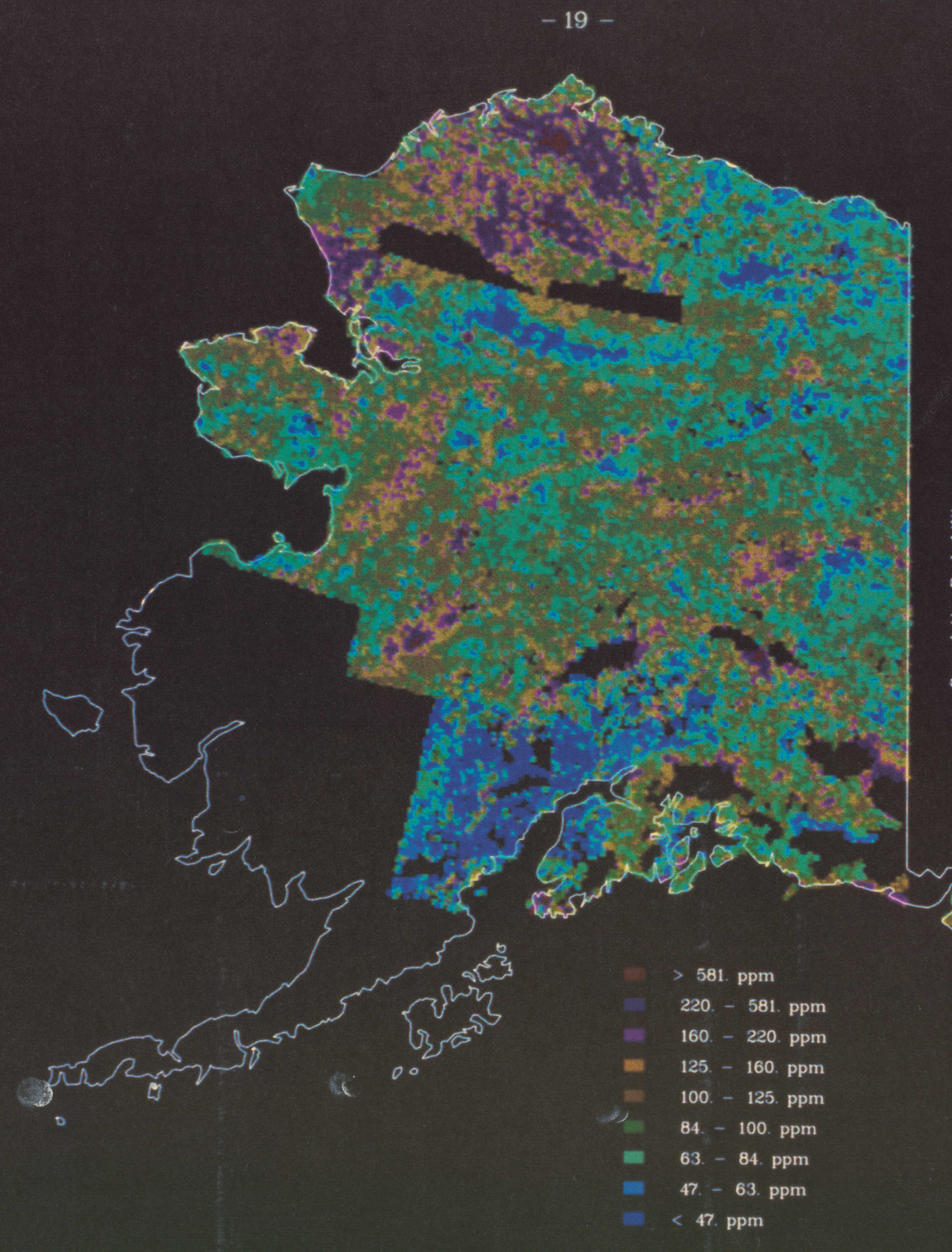

PLATE 11

CHROMIUM

For 57532 Values above Detection Limit

Mean

Minimum

Median

Maximum

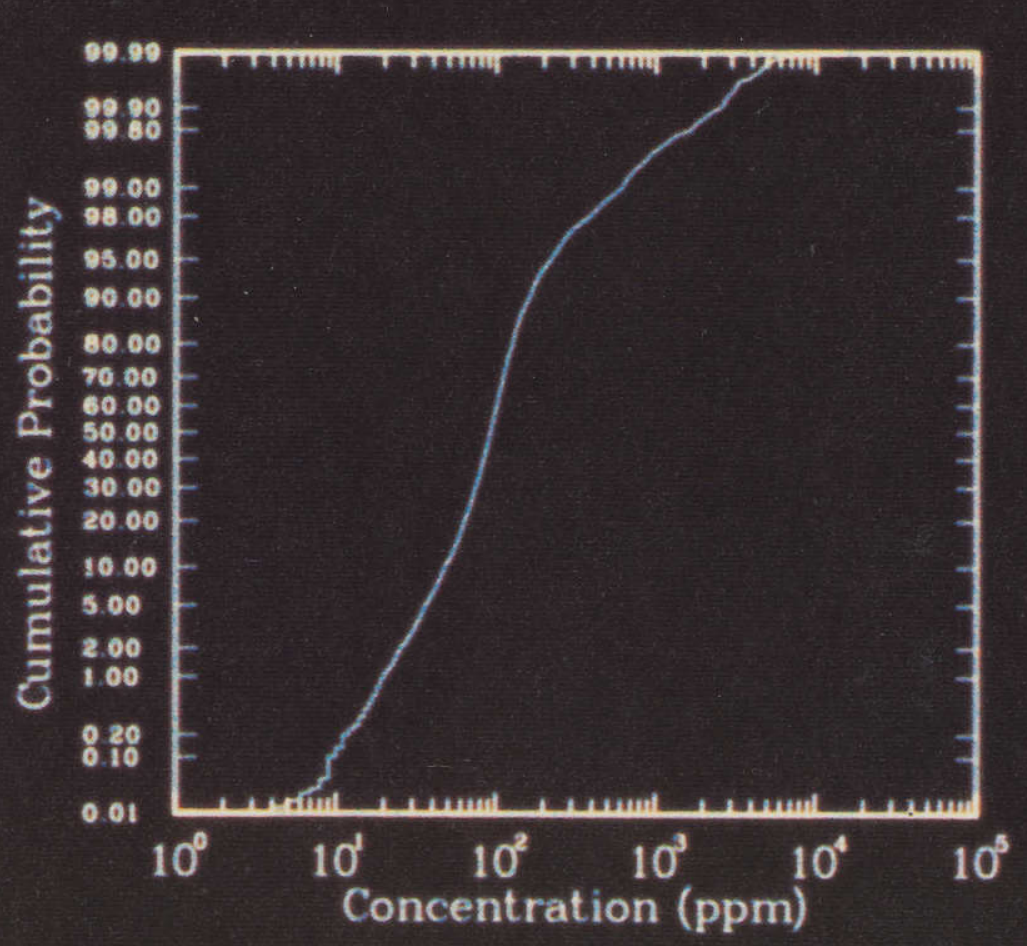


$-20-$

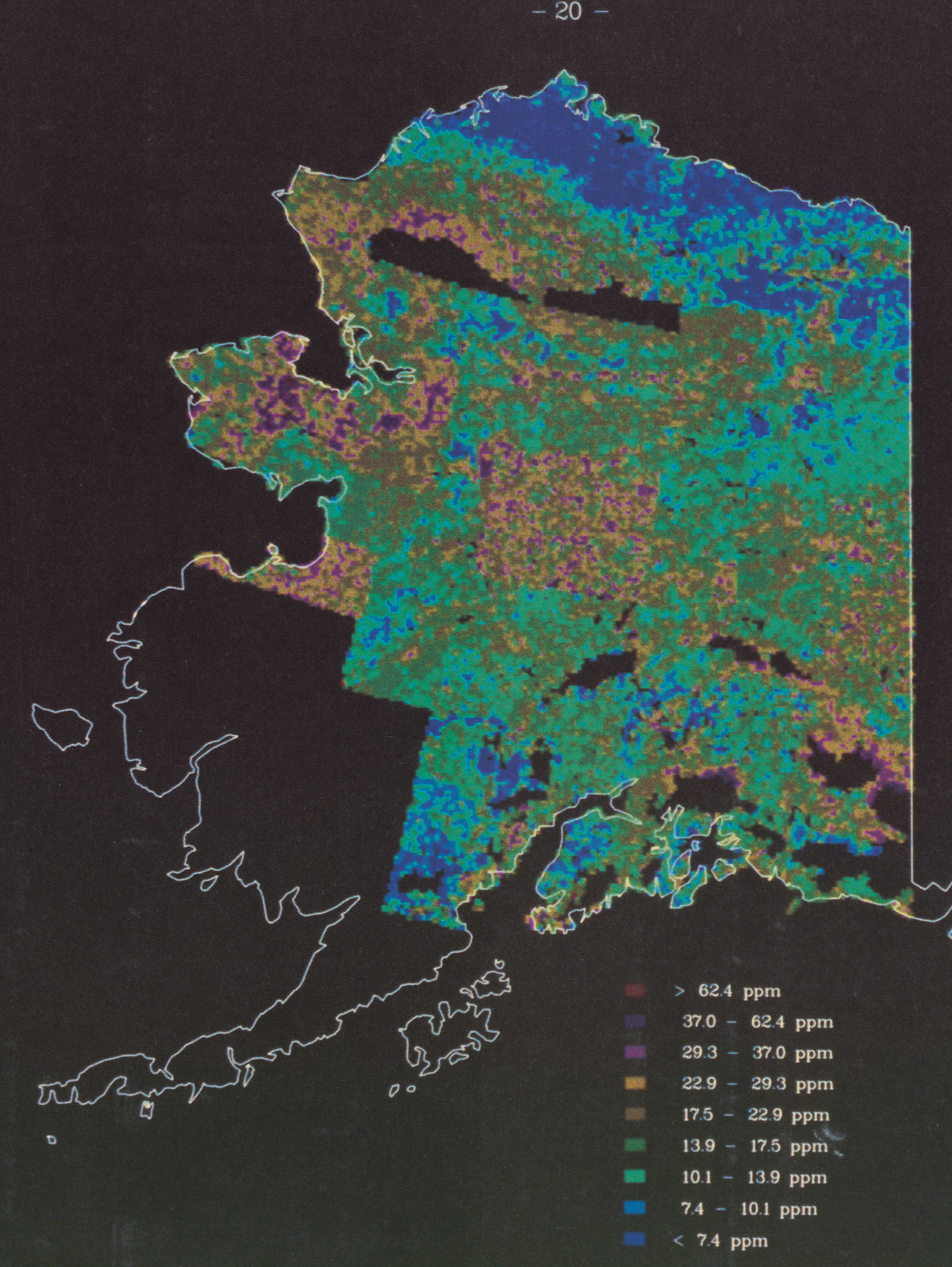

PLATE 12

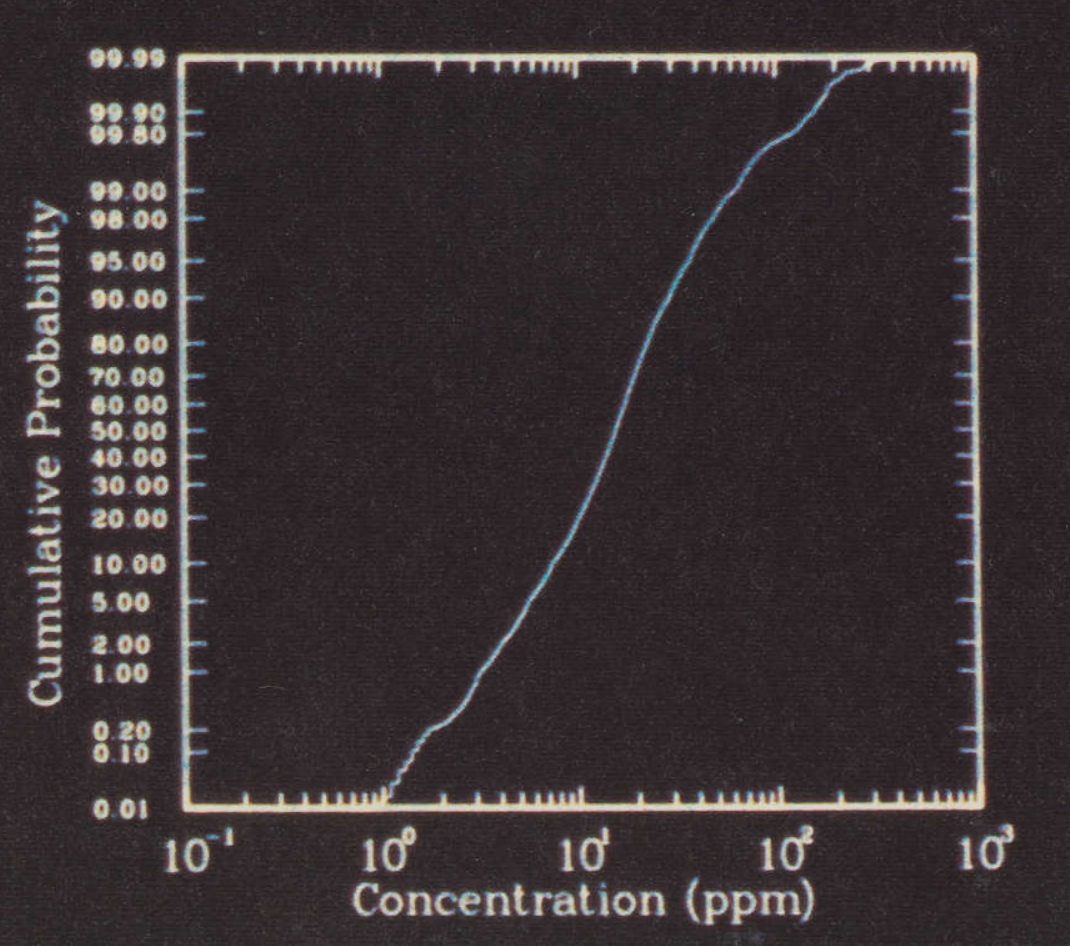

L)
For 58535 Values above Detection Limit

$\begin{array}{ll}\text { Mean } & 18.03 \mathrm{ppm} \\ \text { Minimum } & 0.70 \mathrm{ppm} \\ \text { Median } & 15.60 \mathrm{ppm} \\ \text { Maximum } & 999.90 \mathrm{ppm}\end{array}$

\author{
COBALT
}

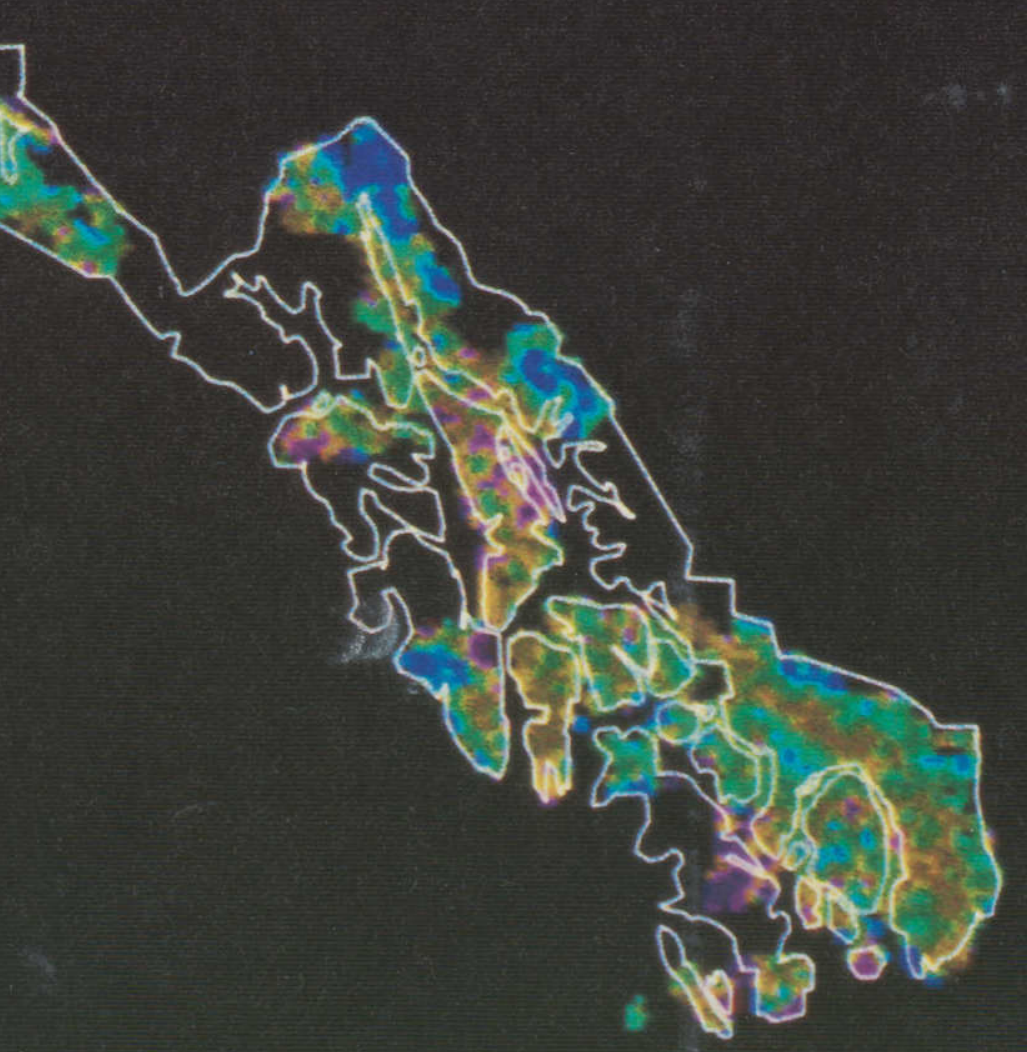




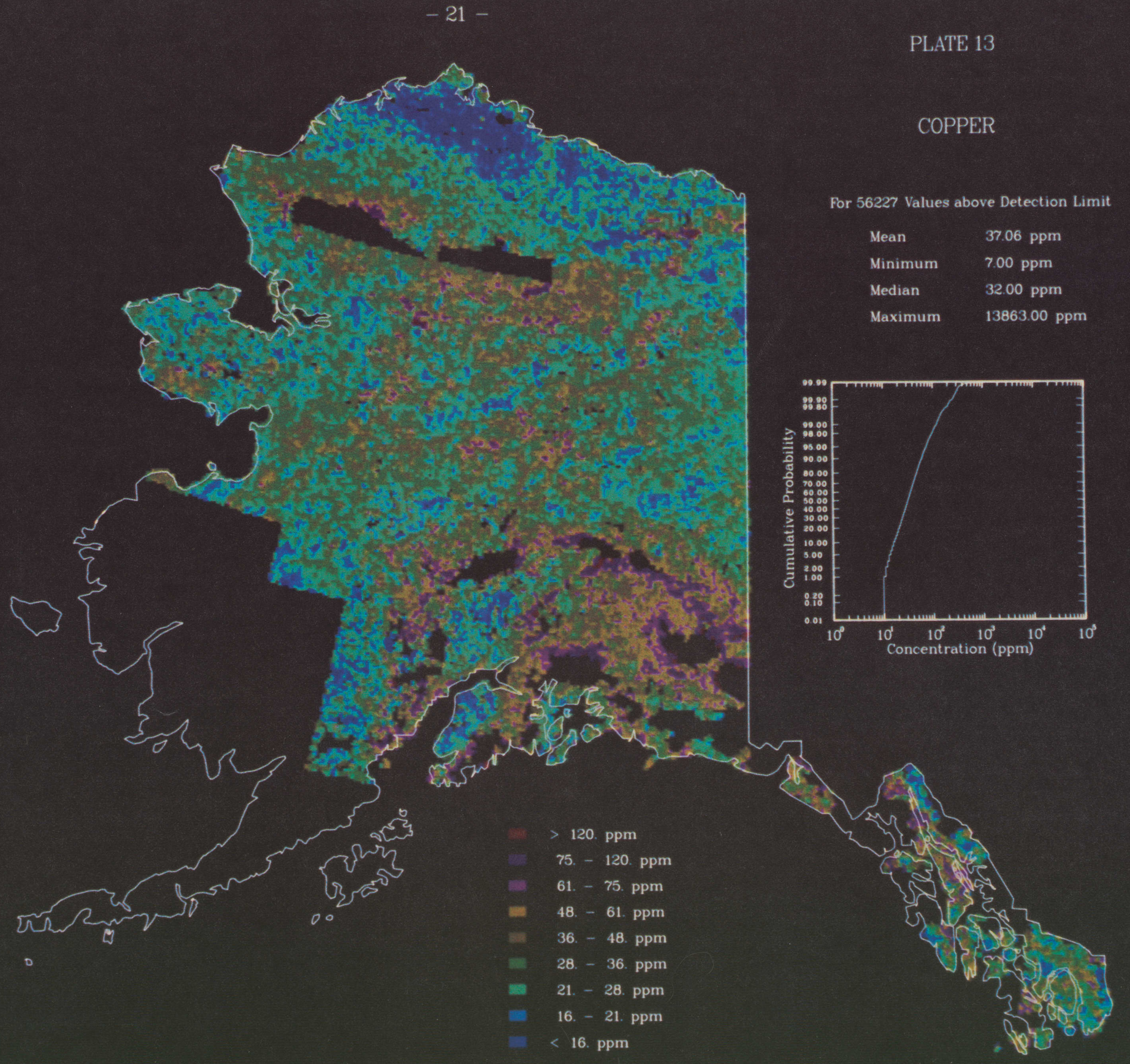




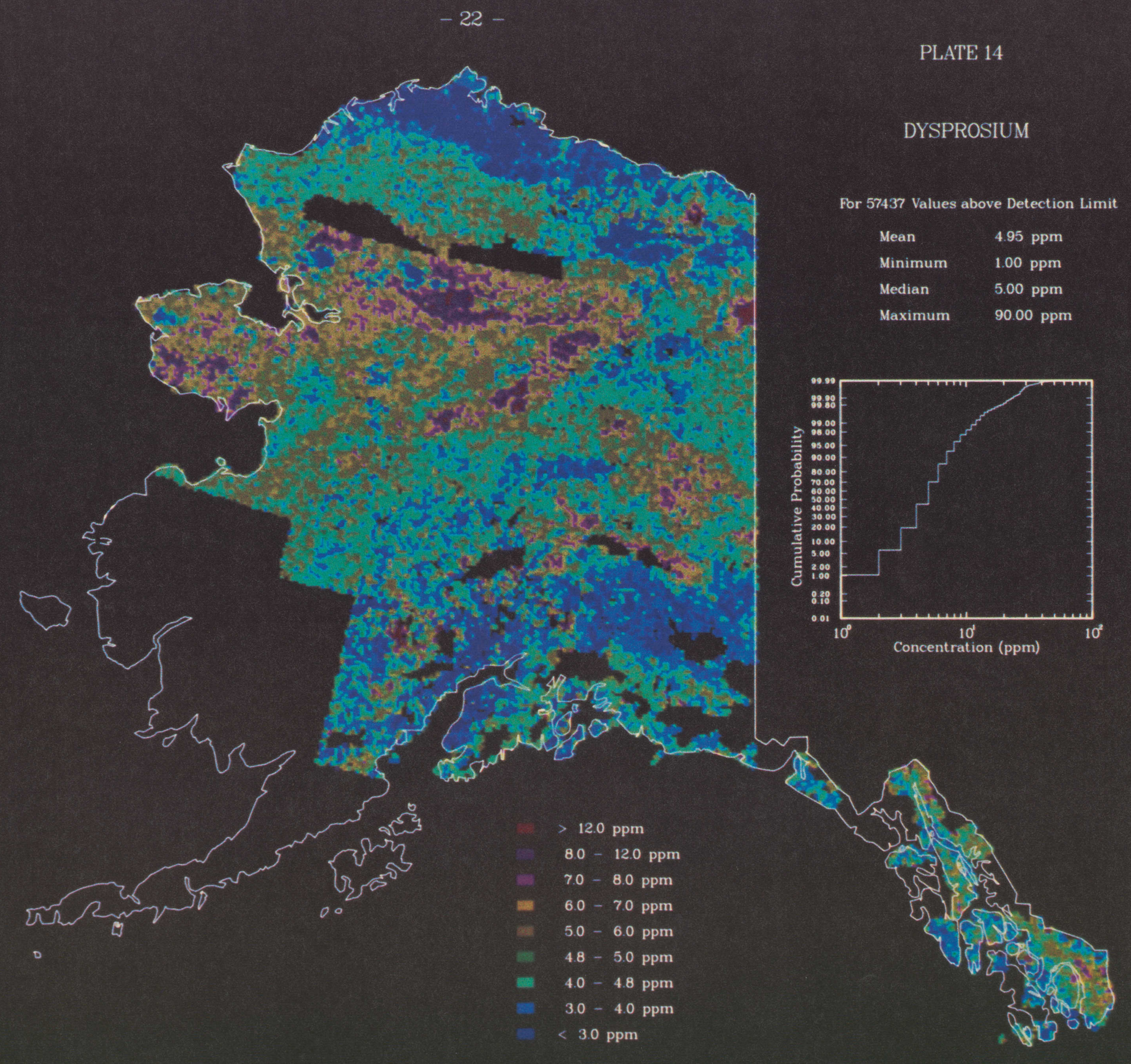


$-23-$

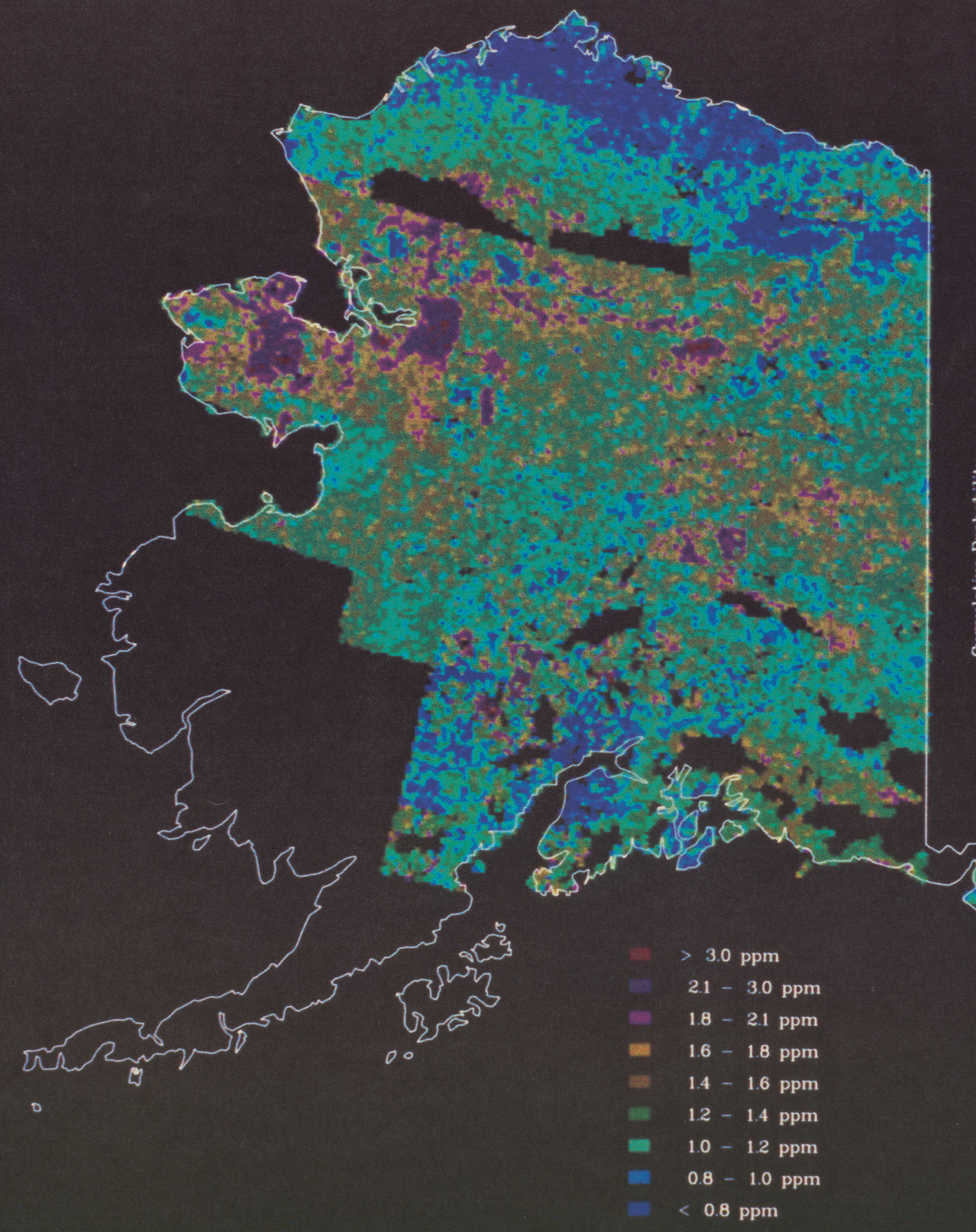

PLATE 15

EUROPIUM

For 56203 Values above Detection Limit

$\begin{array}{ll}\text { Mean } & 1.34 \mathrm{ppm} \\ \text { Minimum } & 0.10 \mathrm{ppm} \\ \text { Median } & 1.30 \mathrm{ppm} \\ \text { Maximum } & 27.80 \mathrm{ppm}\end{array}$
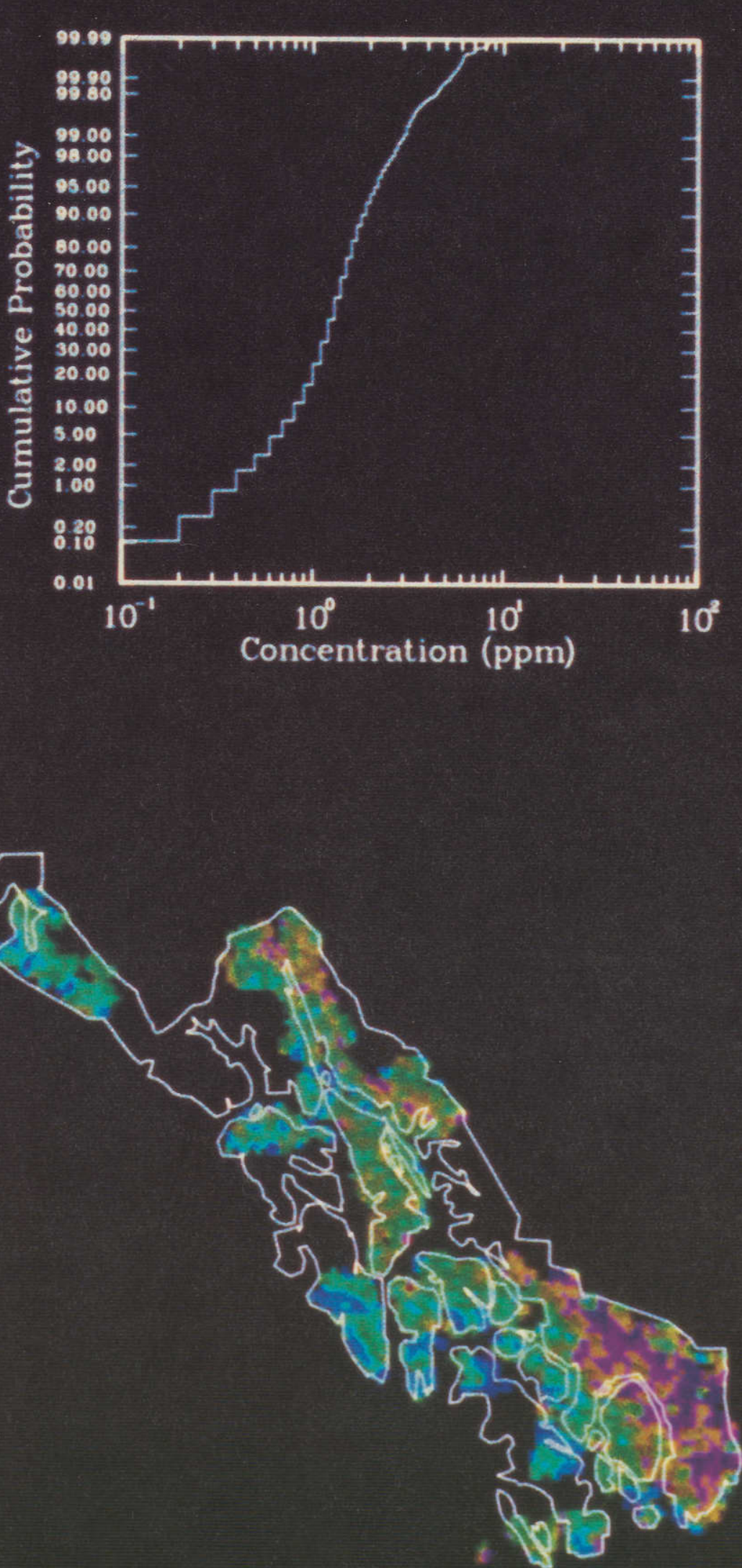


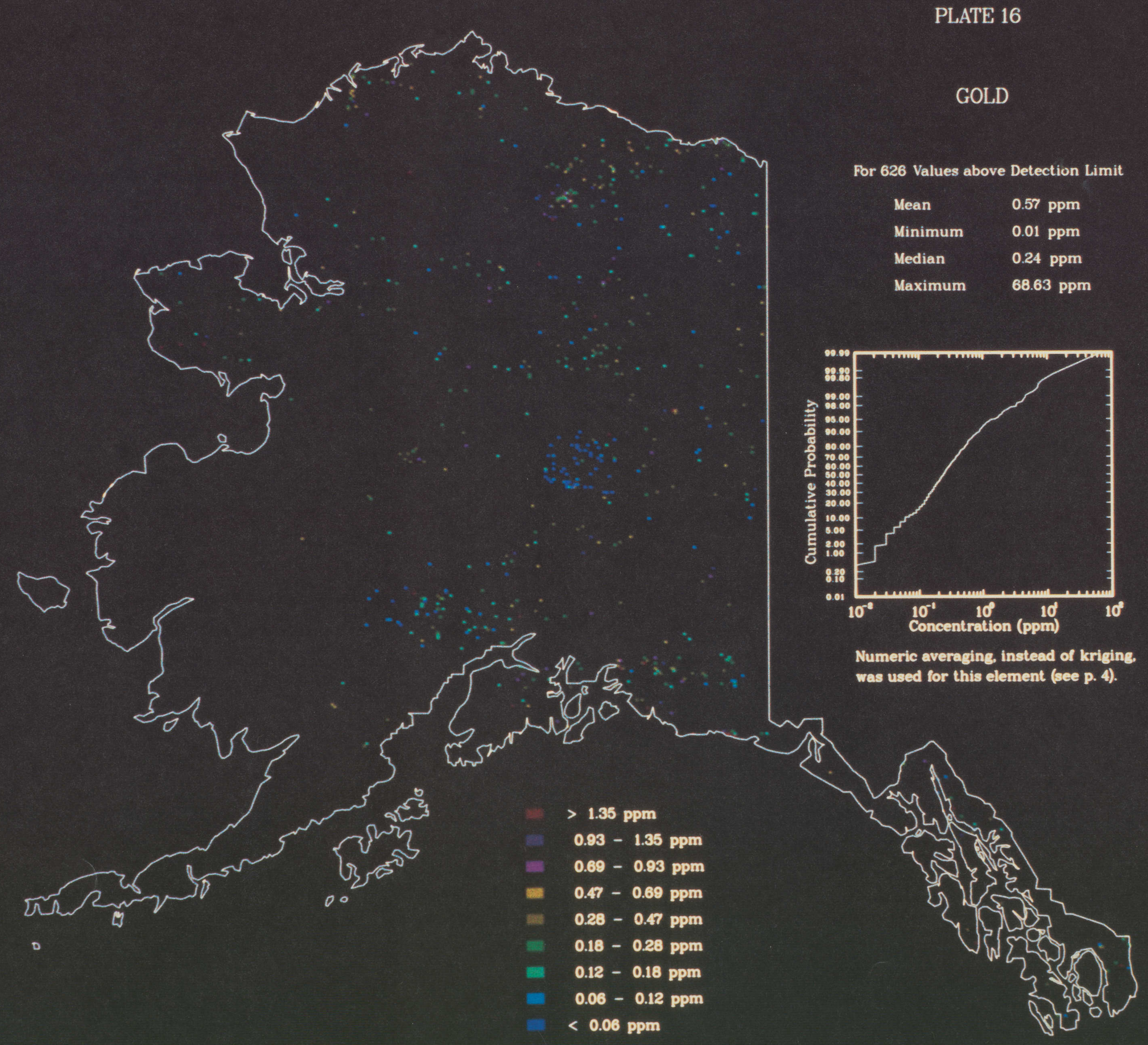




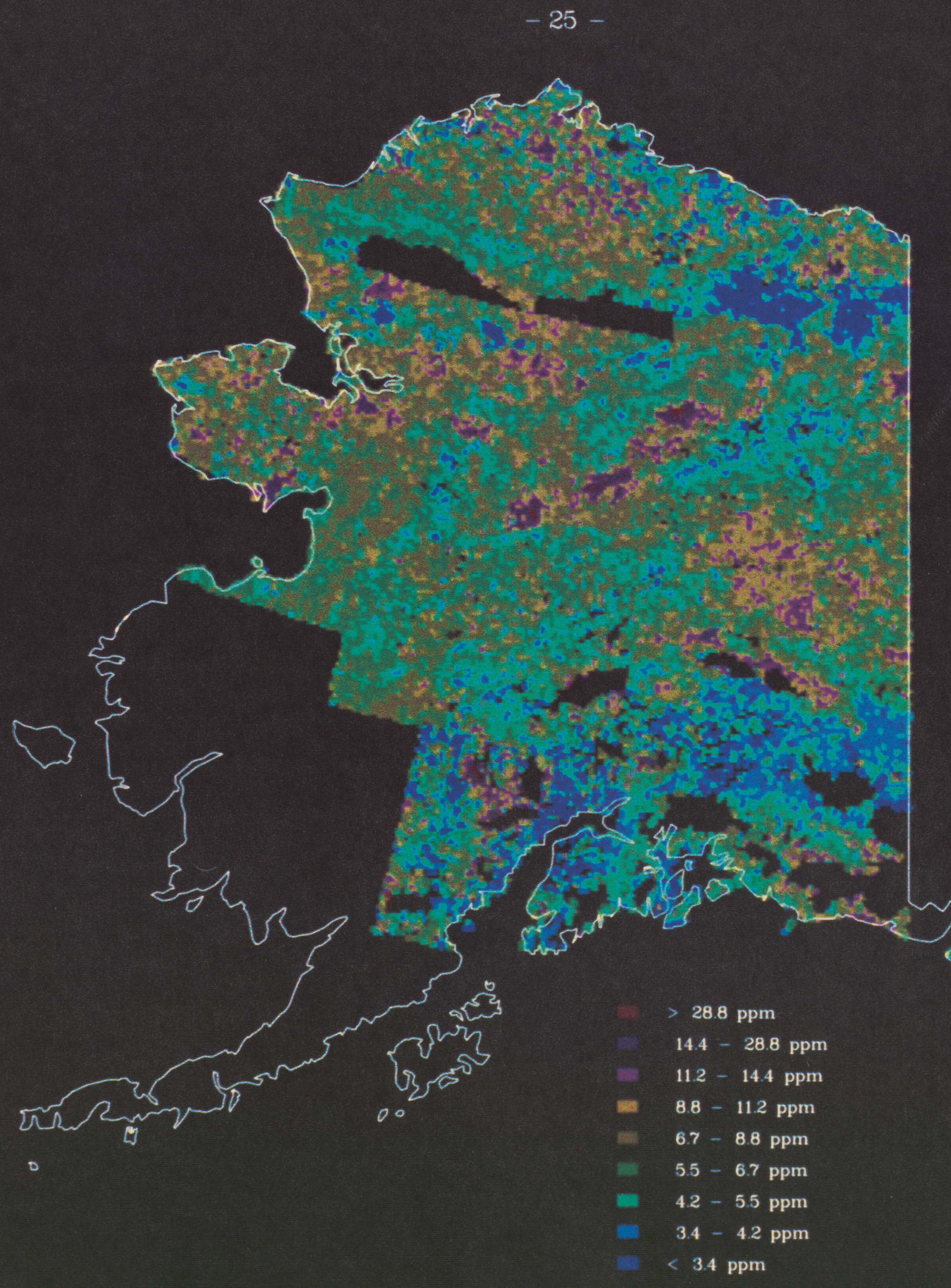

PLATE 17

HAFNIUM

For 54000 Values above Detection Limit

$\begin{array}{ll}\text { Mean } & 7.19 \mathrm{ppm} \\ \text { Minimum } & 0.10 \mathrm{ppm} \\ \text { Median } & 6.00 \mathrm{ppm} \\ \text { Maximum } & 662.00 \mathrm{ppm}\end{array}$
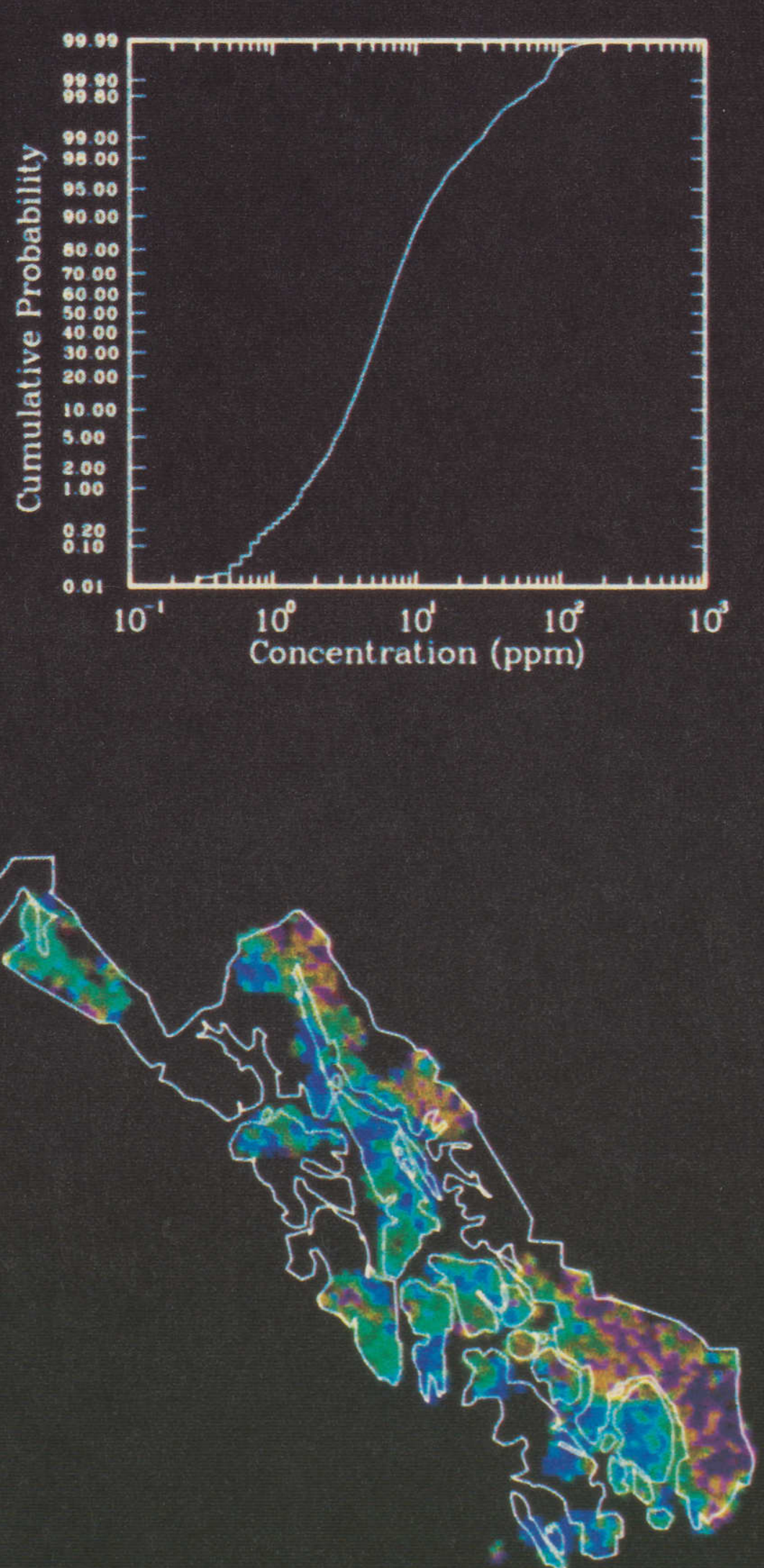


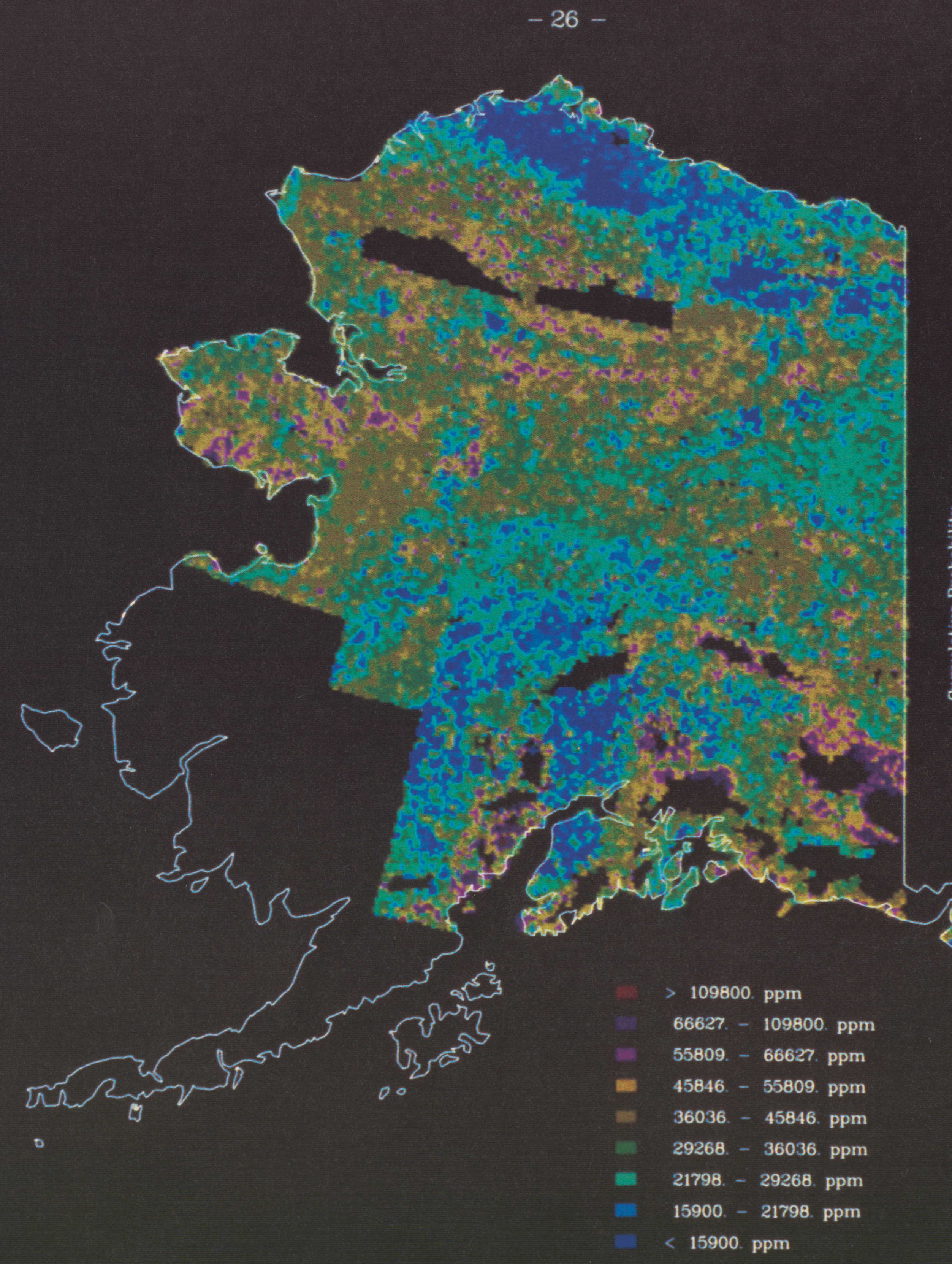

PLATE 18

IRON

For 61331 Values above Detection Limit

Mean

Minimum

Median

Maximum

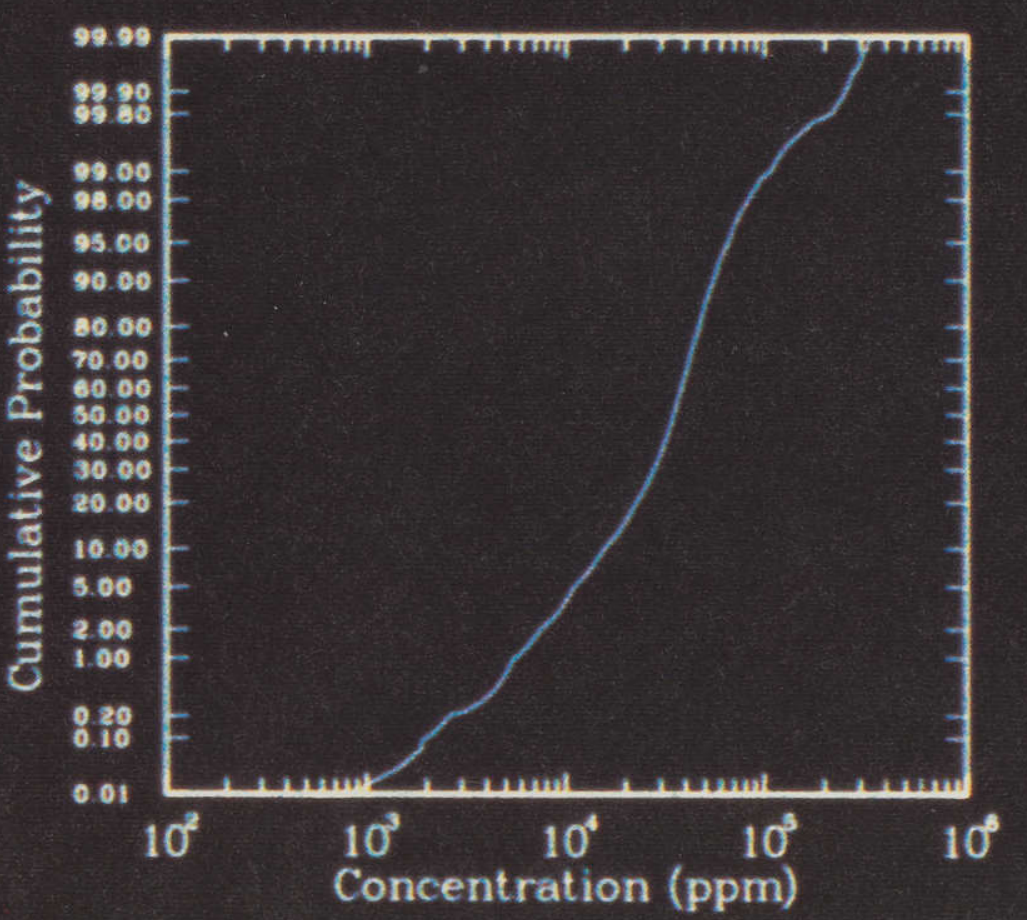

$36776.21 \mathrm{ppm}$

$517.00 \mathrm{ppm}$

$35030.00 \mathrm{ppm}$

$491800.00 \mathrm{ppm}$ 


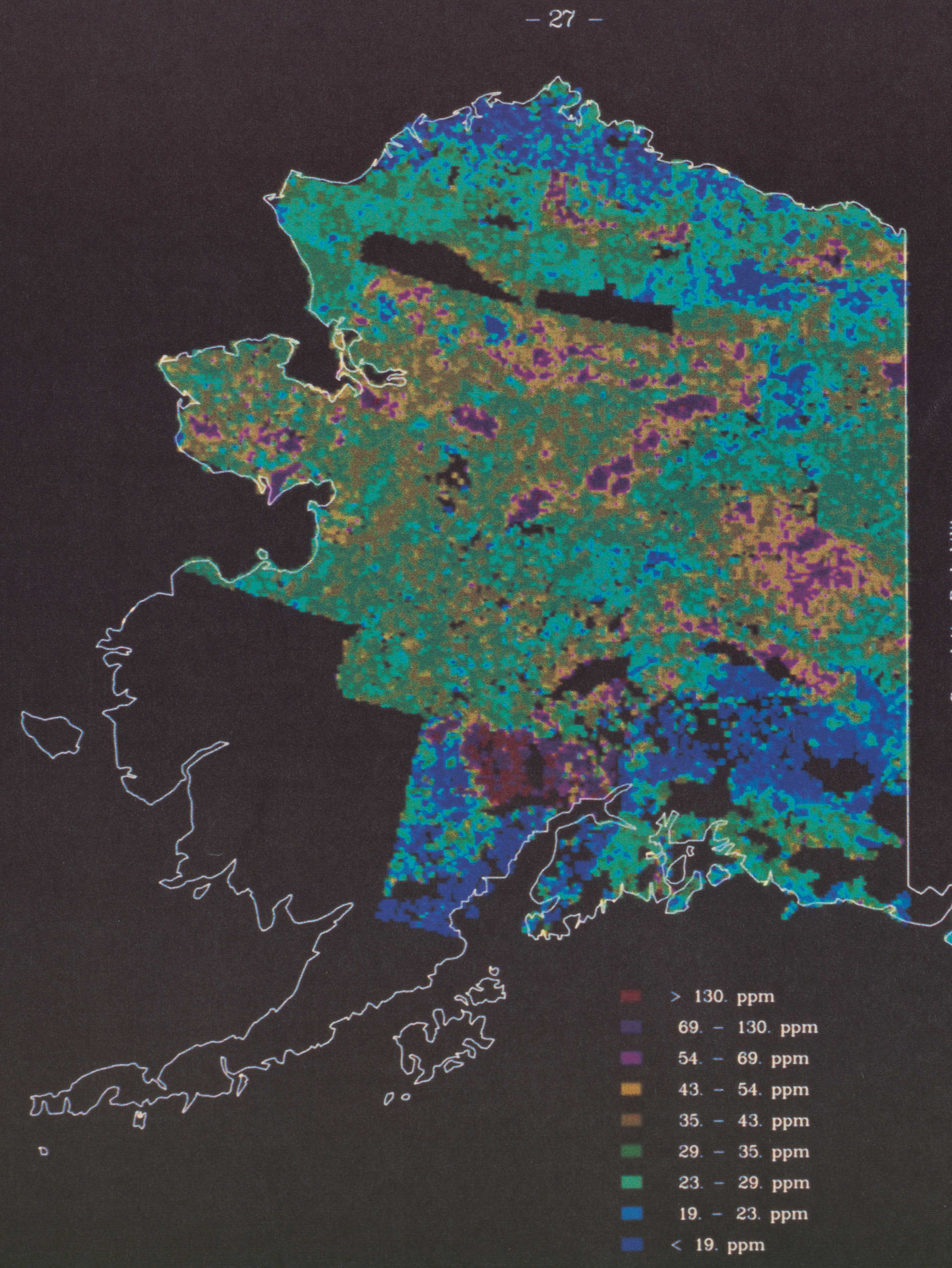

PLATE 19

LANTHANUM

For 49039 Values above Detection Limit

Mean

Minimum

Median

Maximum

$36.48 \mathrm{ppm}$

$1.00 \mathrm{ppm}$

$32.00 \mathrm{ppm}$

$899.00 \mathrm{ppm}$
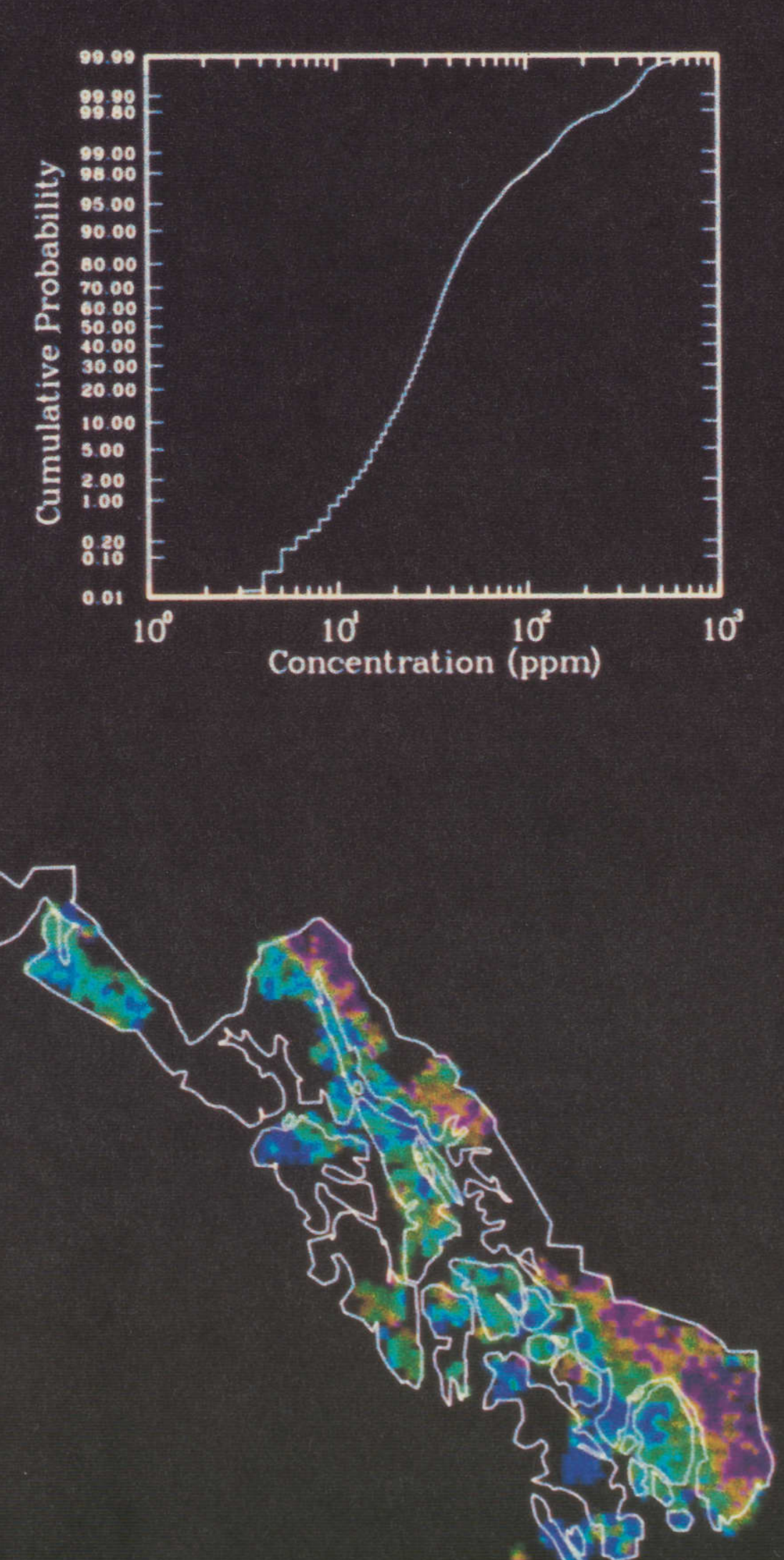


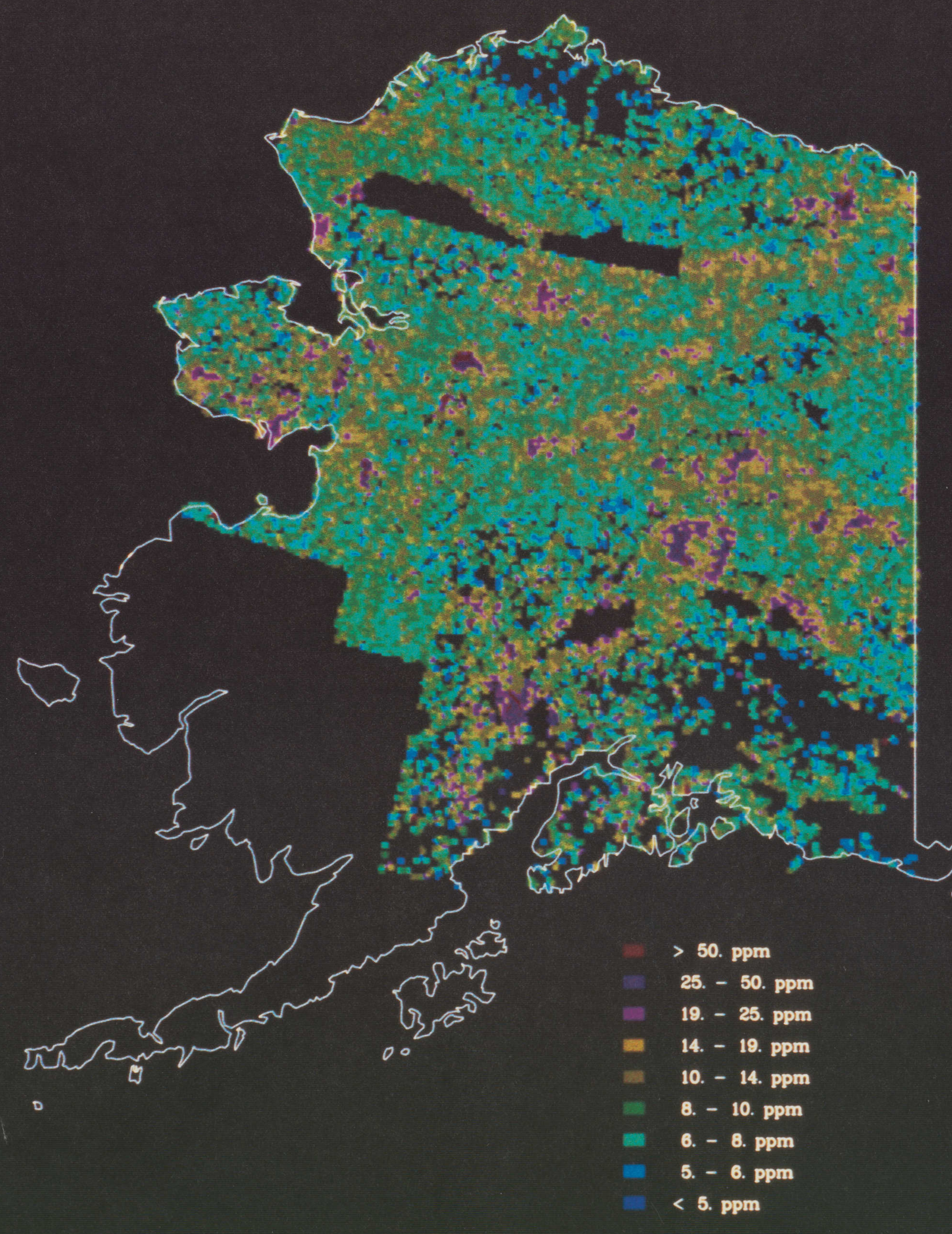

PLATE 20

LEAD

For 34138 Values above Detection Limit

Mean

Minimum

Median

Maximum

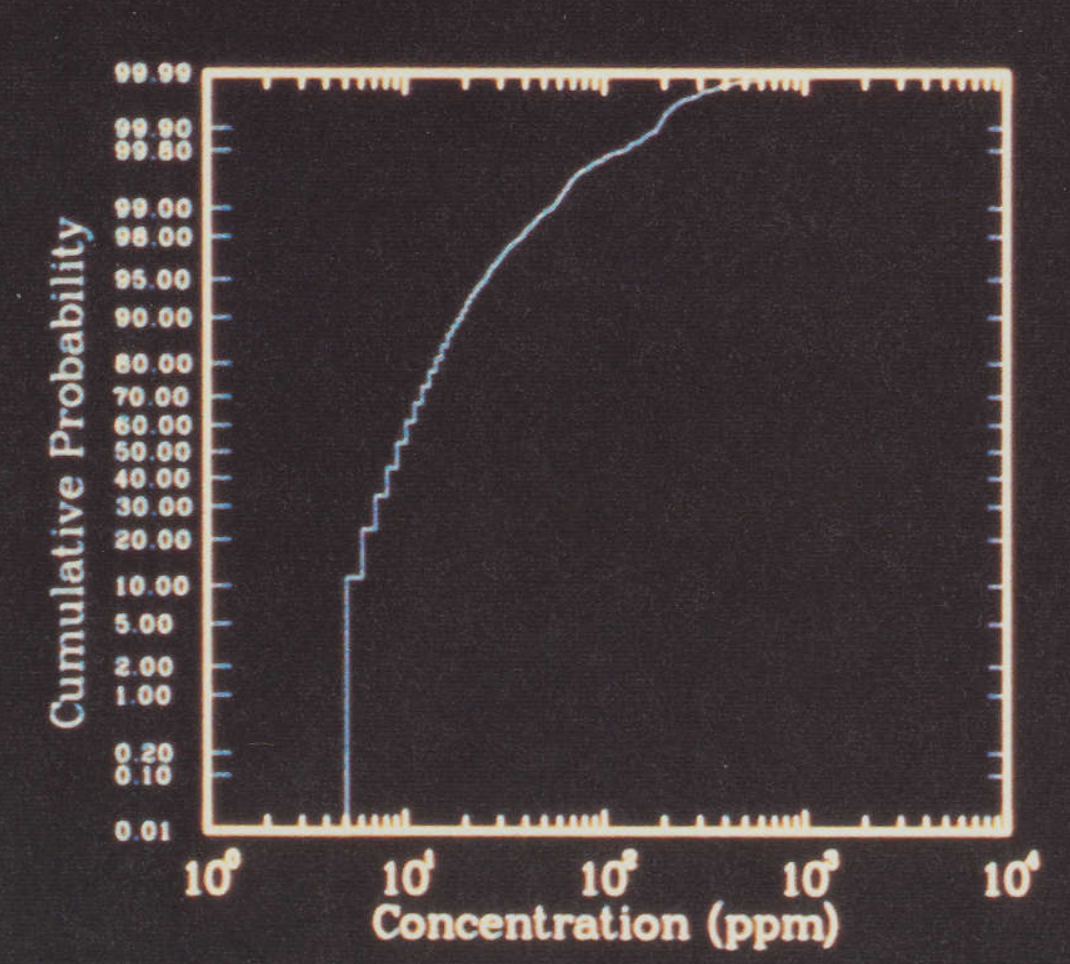

$12.41 \mathrm{ppm}$

$4.00 \mathrm{ppm}$

$9.00 \mathrm{ppm}$

$9926.00 \mathrm{ppm}$

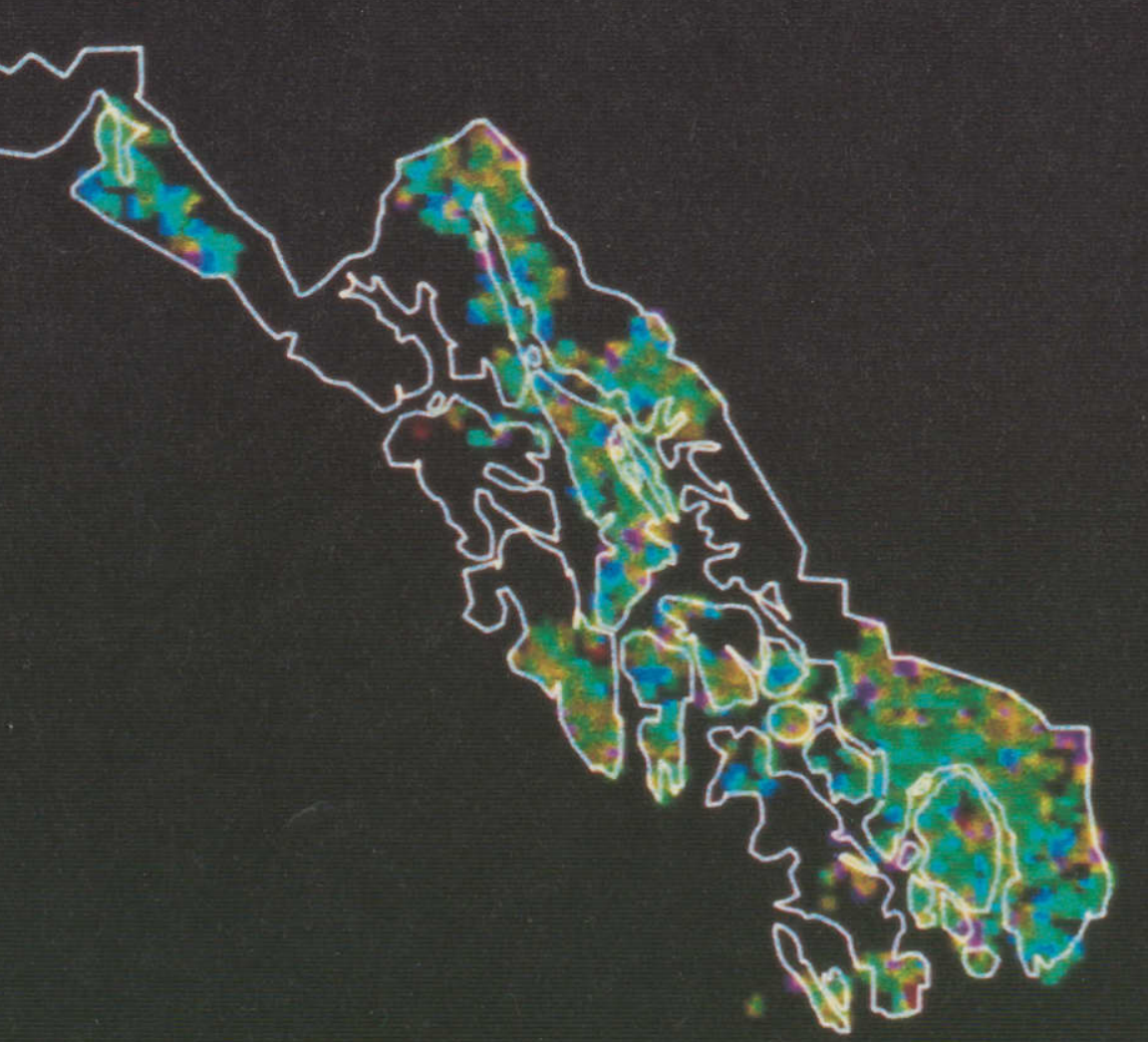


$-29-$

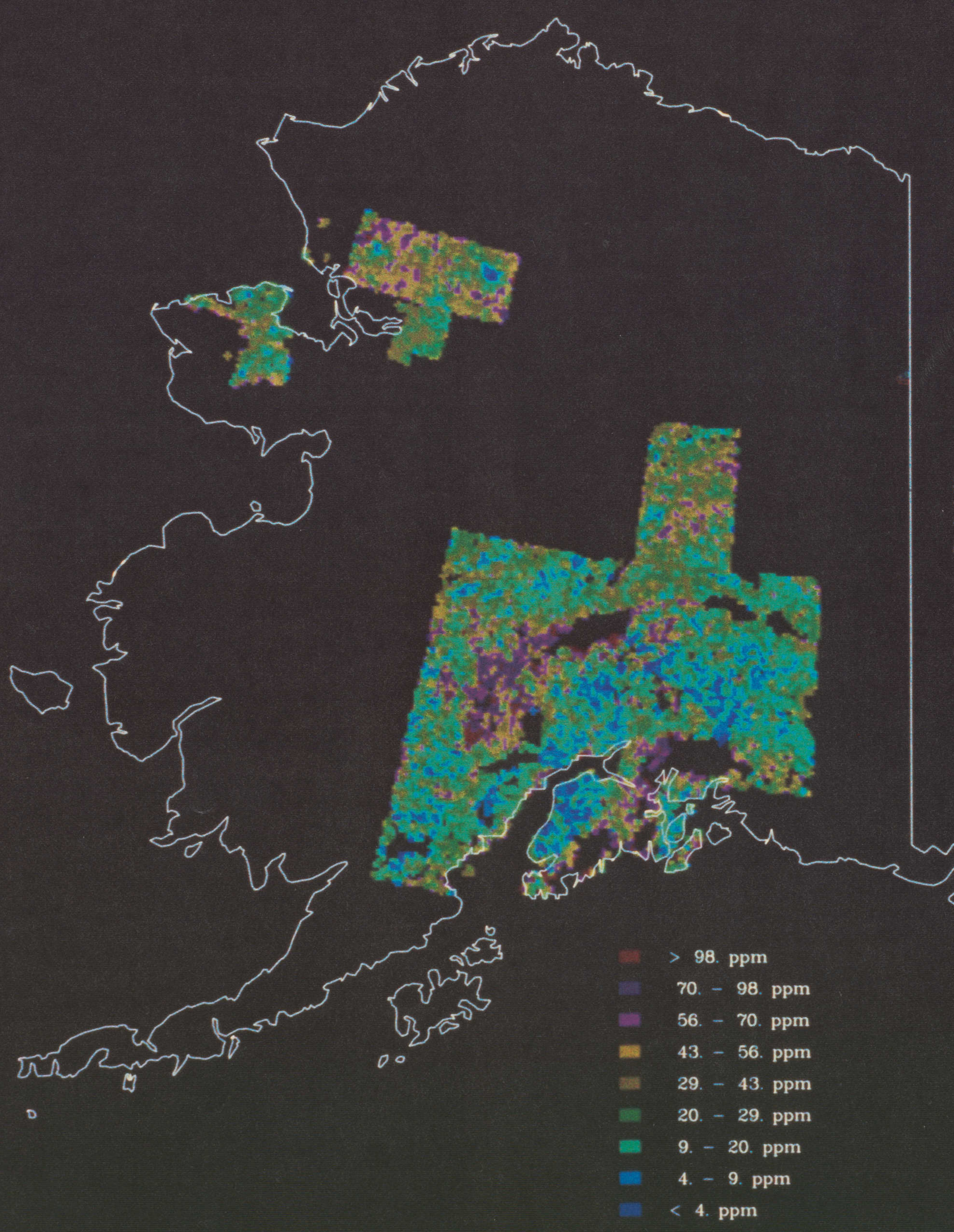

PLATE 21

LITHIUM

For 15554 Values above Detection Limit

Mean

$\quad 1.00 \mathrm{ppm}$

Median $\quad 25.00 \mathrm{ppm}$

Maximum $\quad 258.00 \mathrm{ppm}$
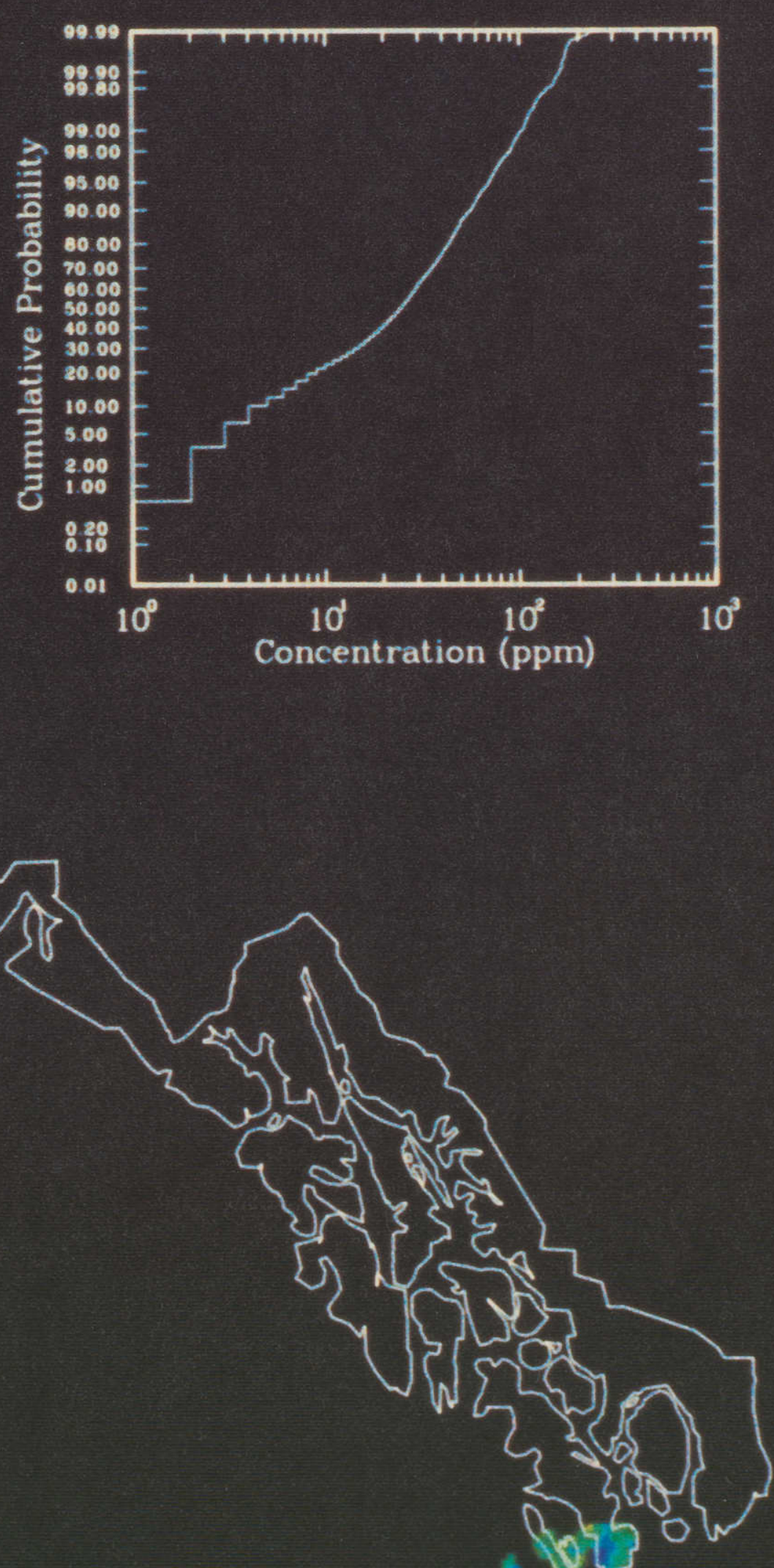


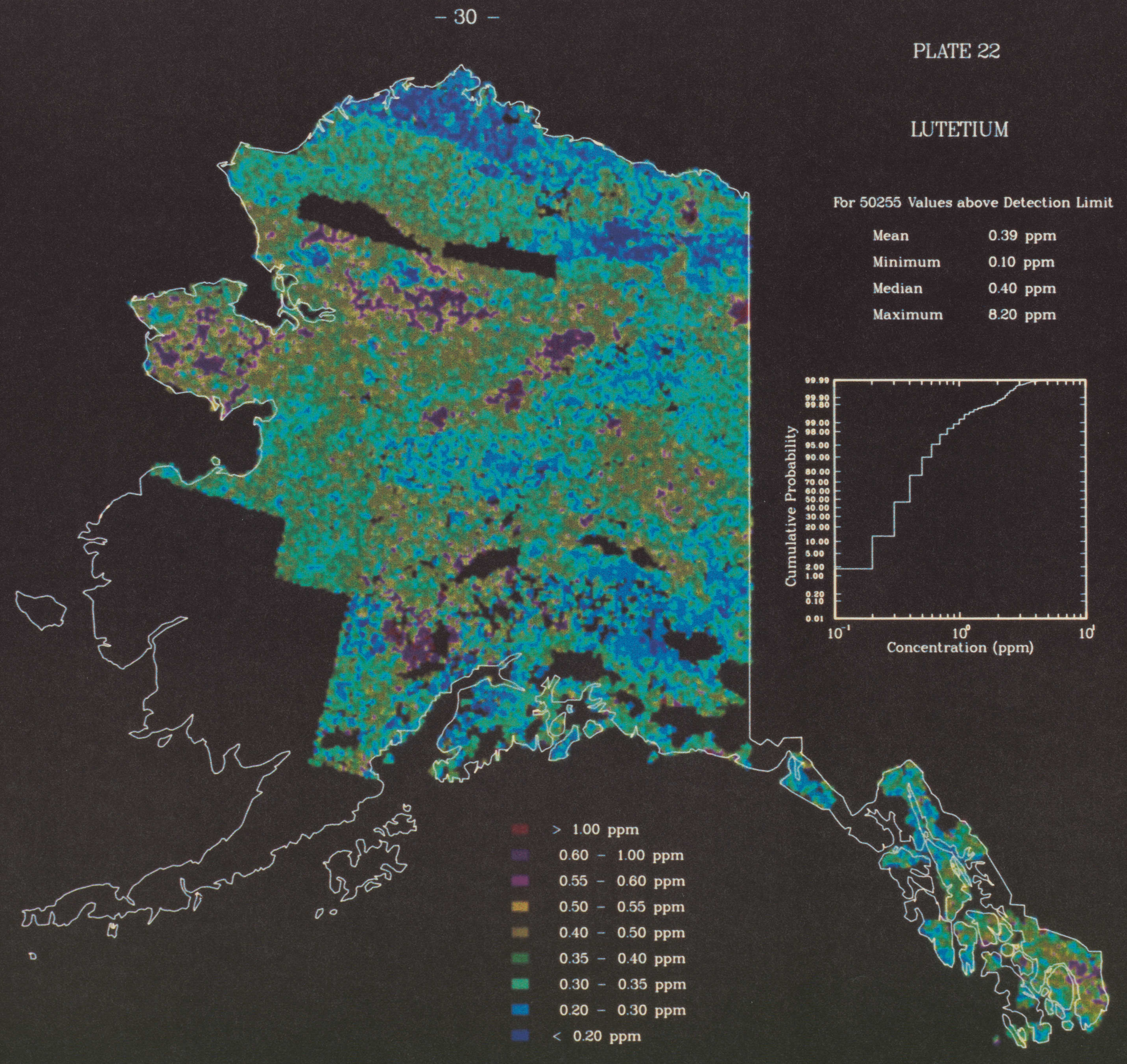




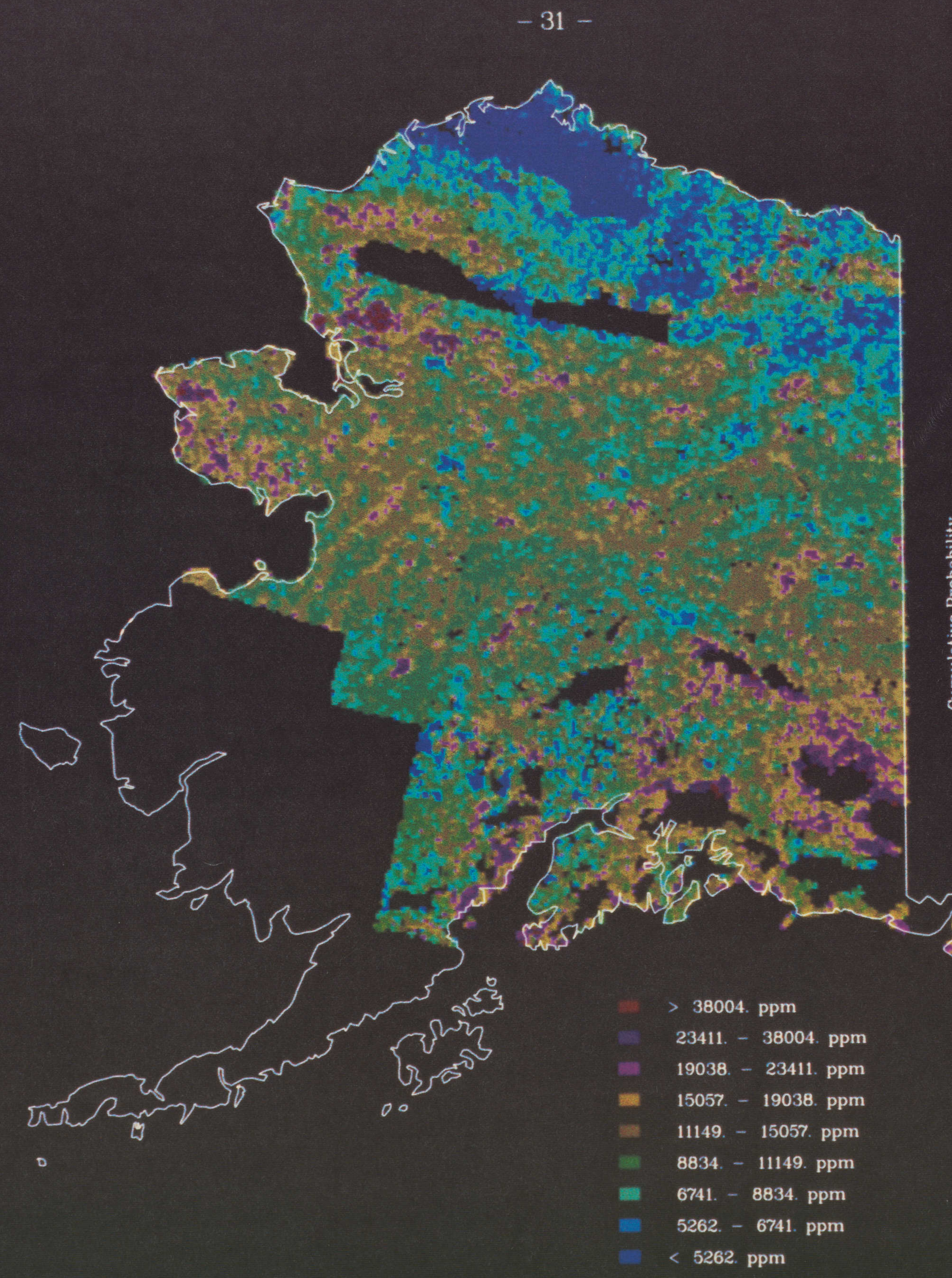

PLATE 23

MAGNESIUM

For 55963 Values above Detection Limit

Mean 12717.14 ppm

Minimum $419.23 \mathrm{ppm}$

Median $11228.10 \mathrm{ppm}$

Maximum $460554.00 \mathrm{ppm}$
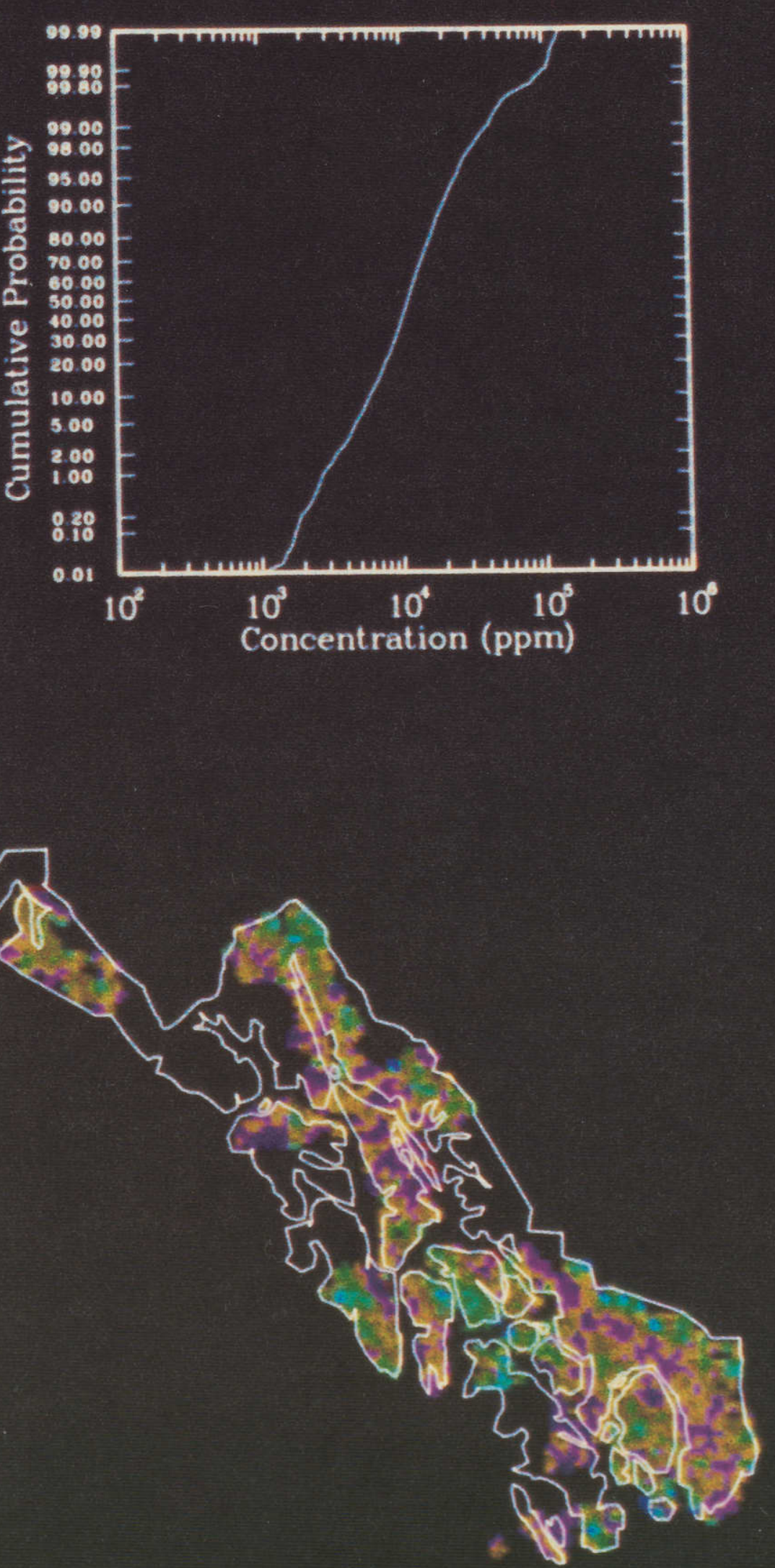


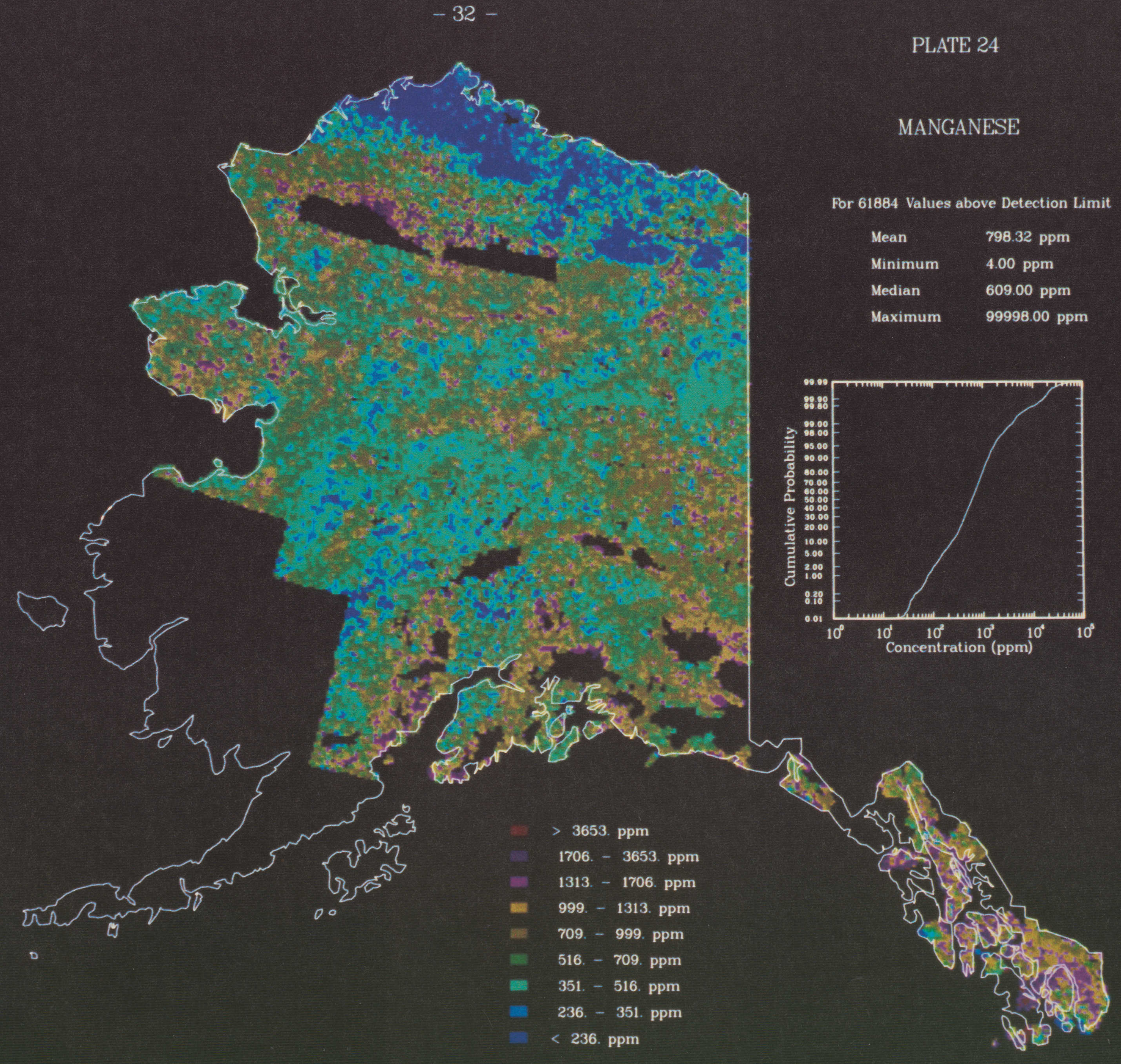




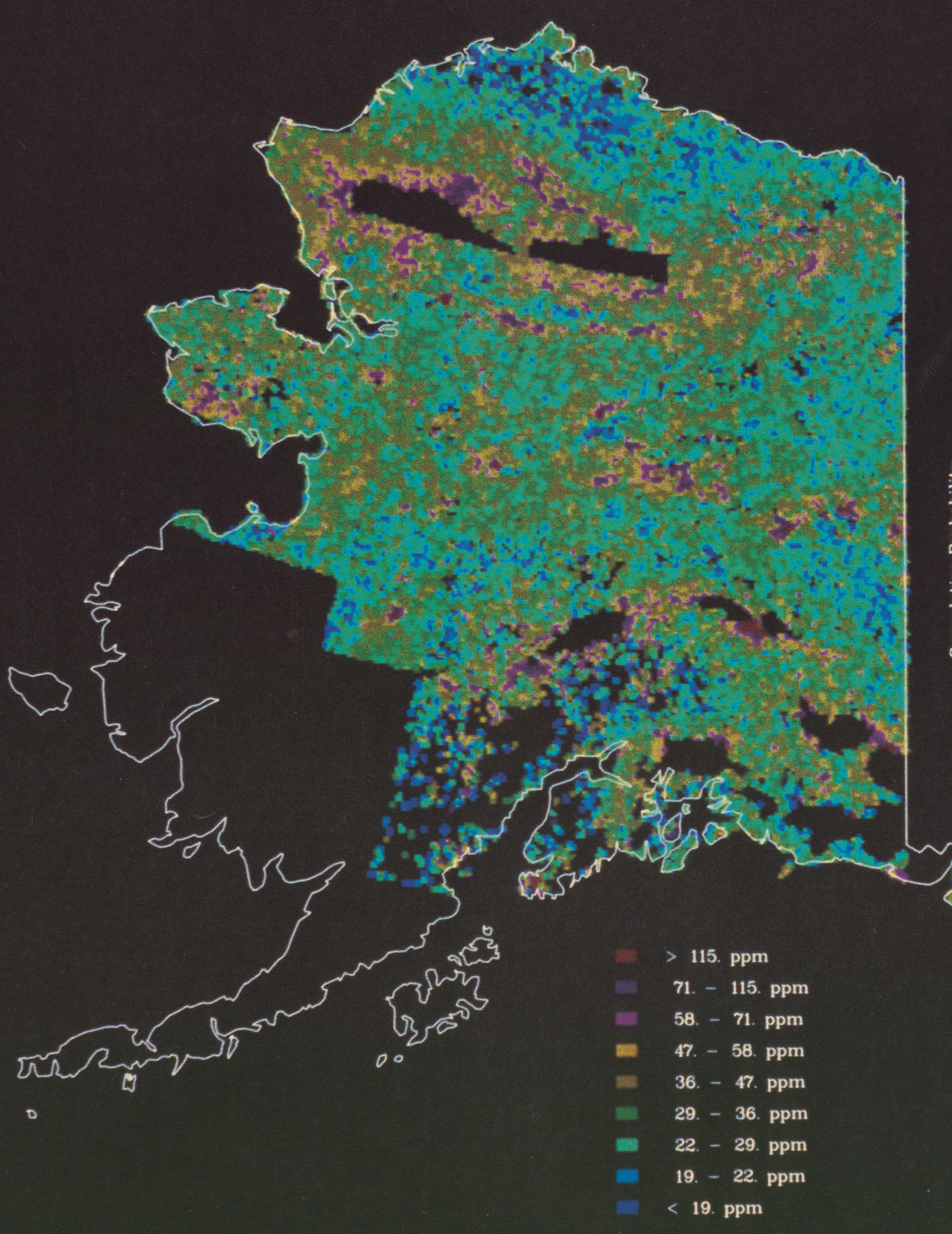

PLATE 25

NICKEL

For 47426 Values above Detection Limit

Mean

Minimum

Median

Maximum

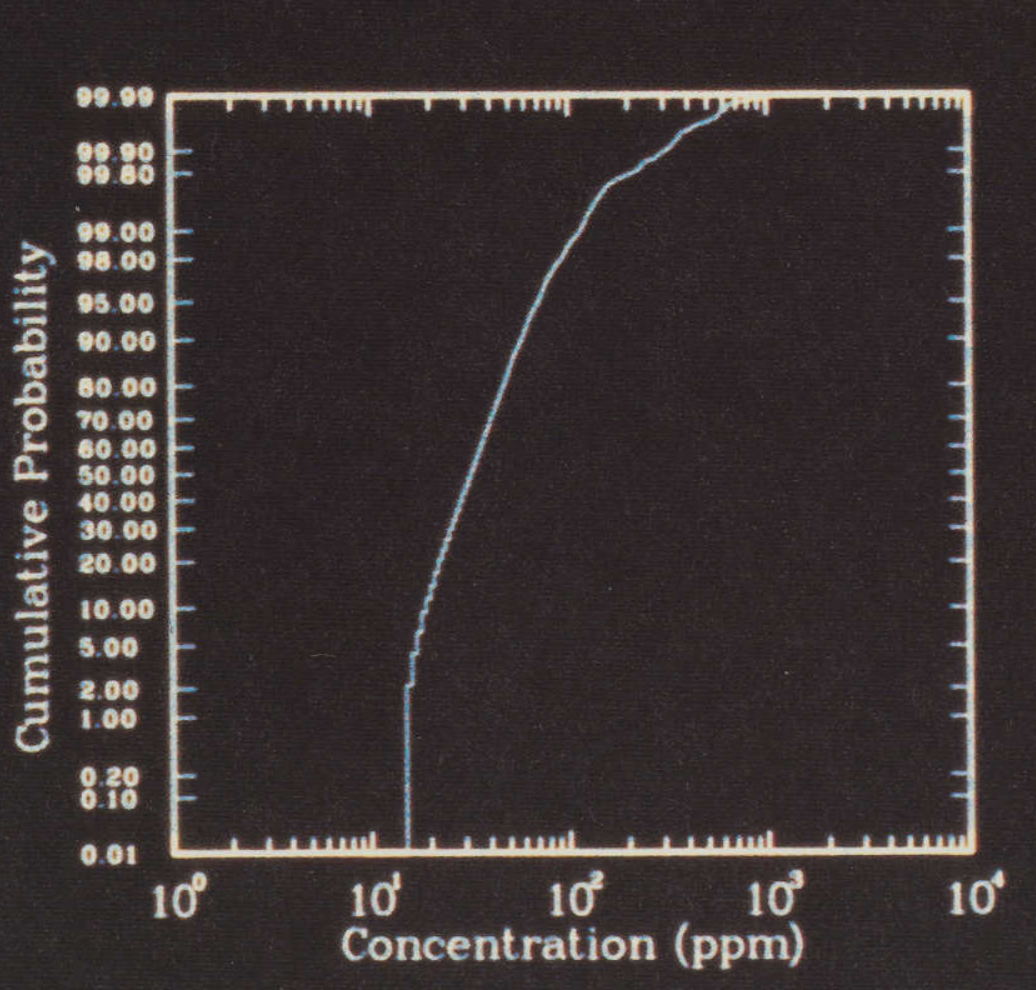

37.27 ppm

$9.00 \mathrm{ppm}$

$32.00 \mathrm{ppm}$

$1829.00 \mathrm{ppm}$

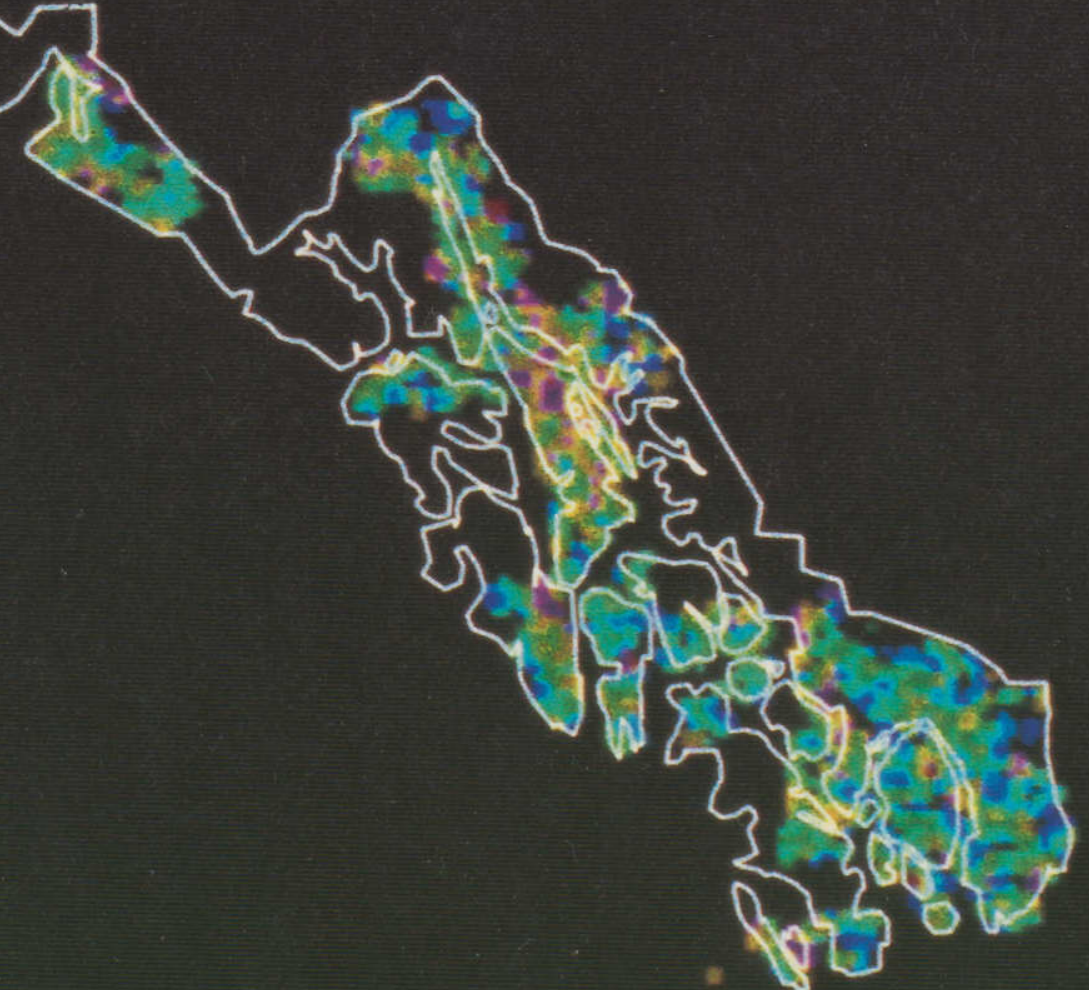




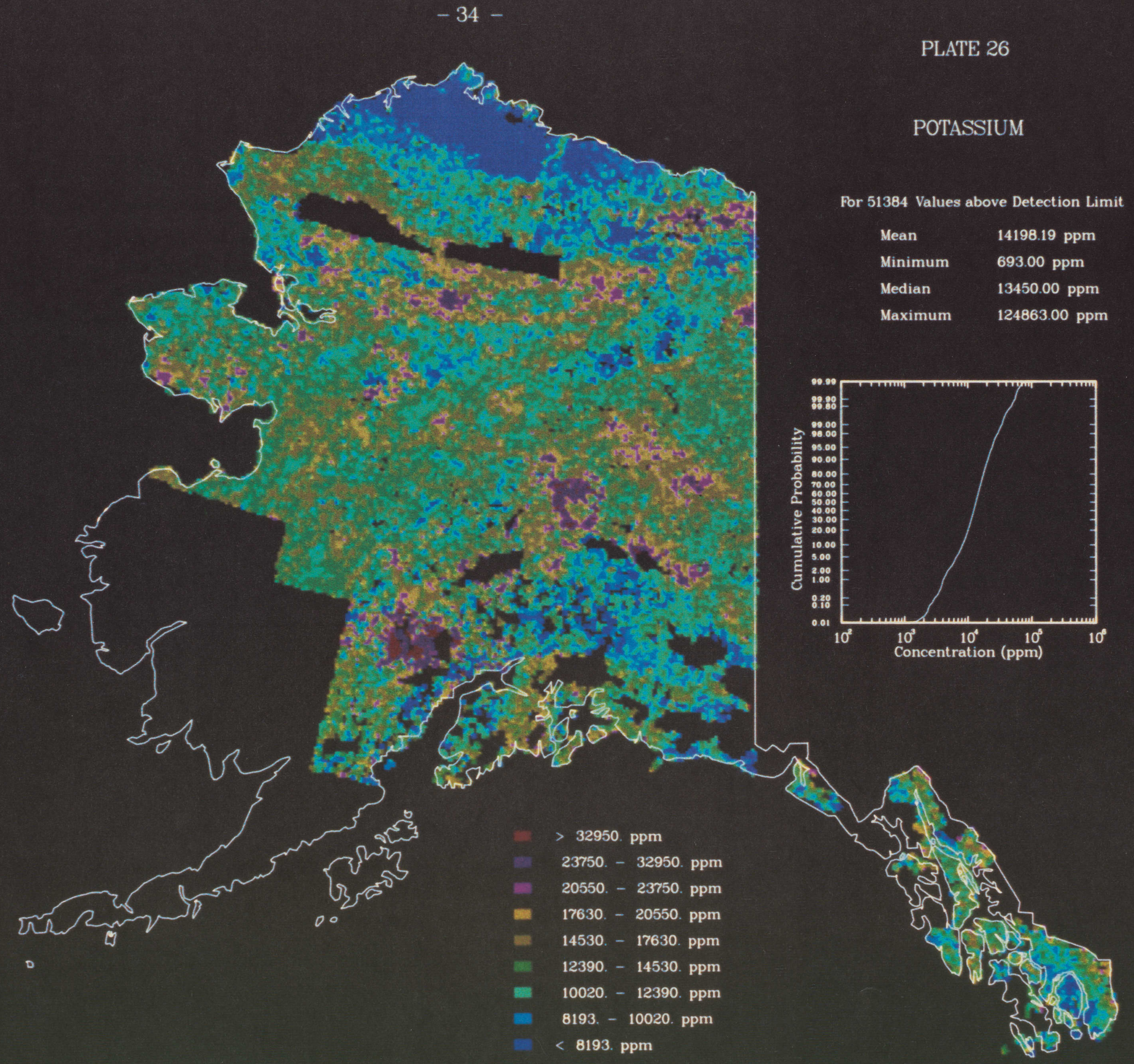




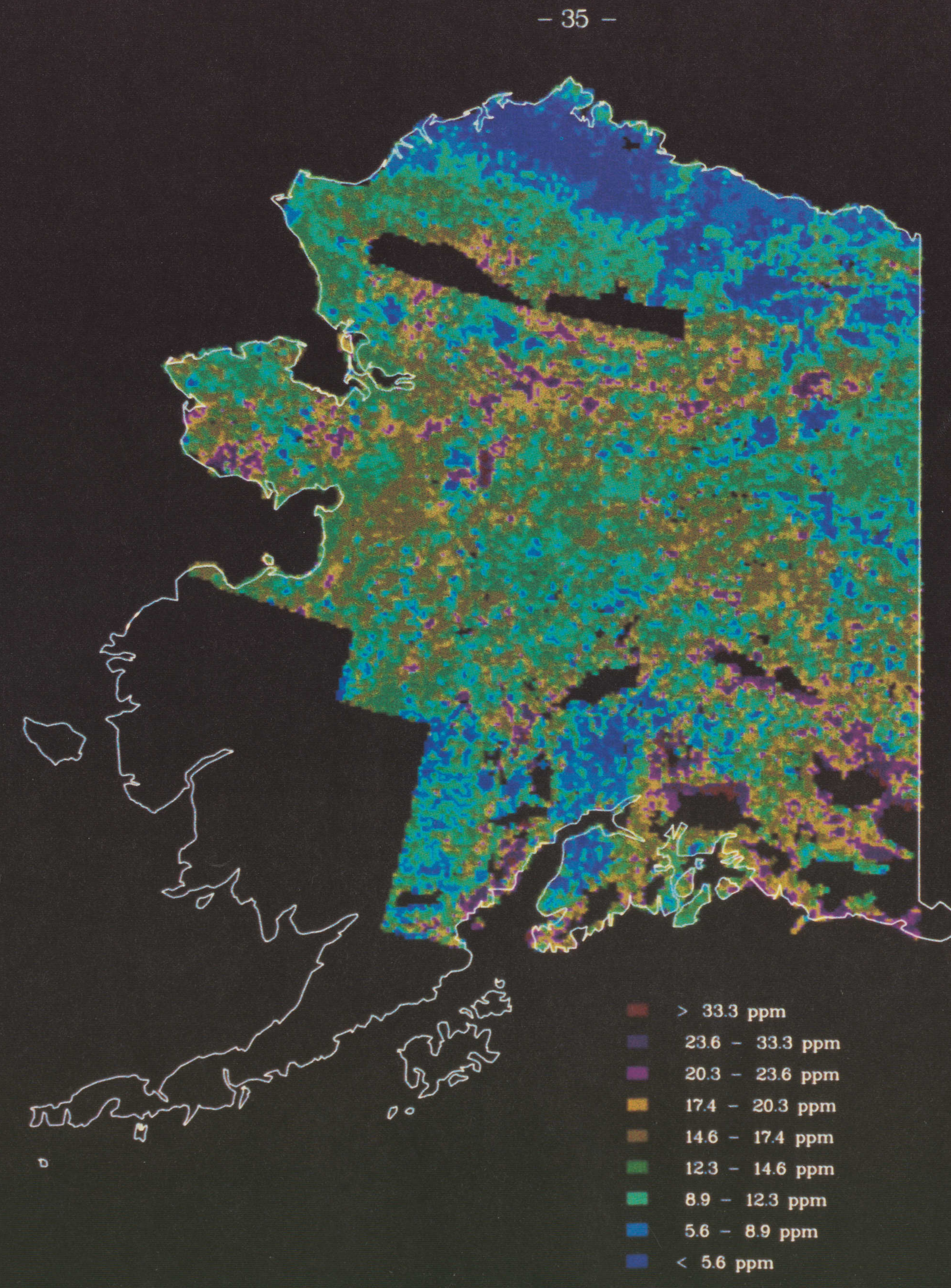

PLATE 27

SCANDIUM

For 61603 Values above Detection Limit

Mean

Minimum

Median

Maximum

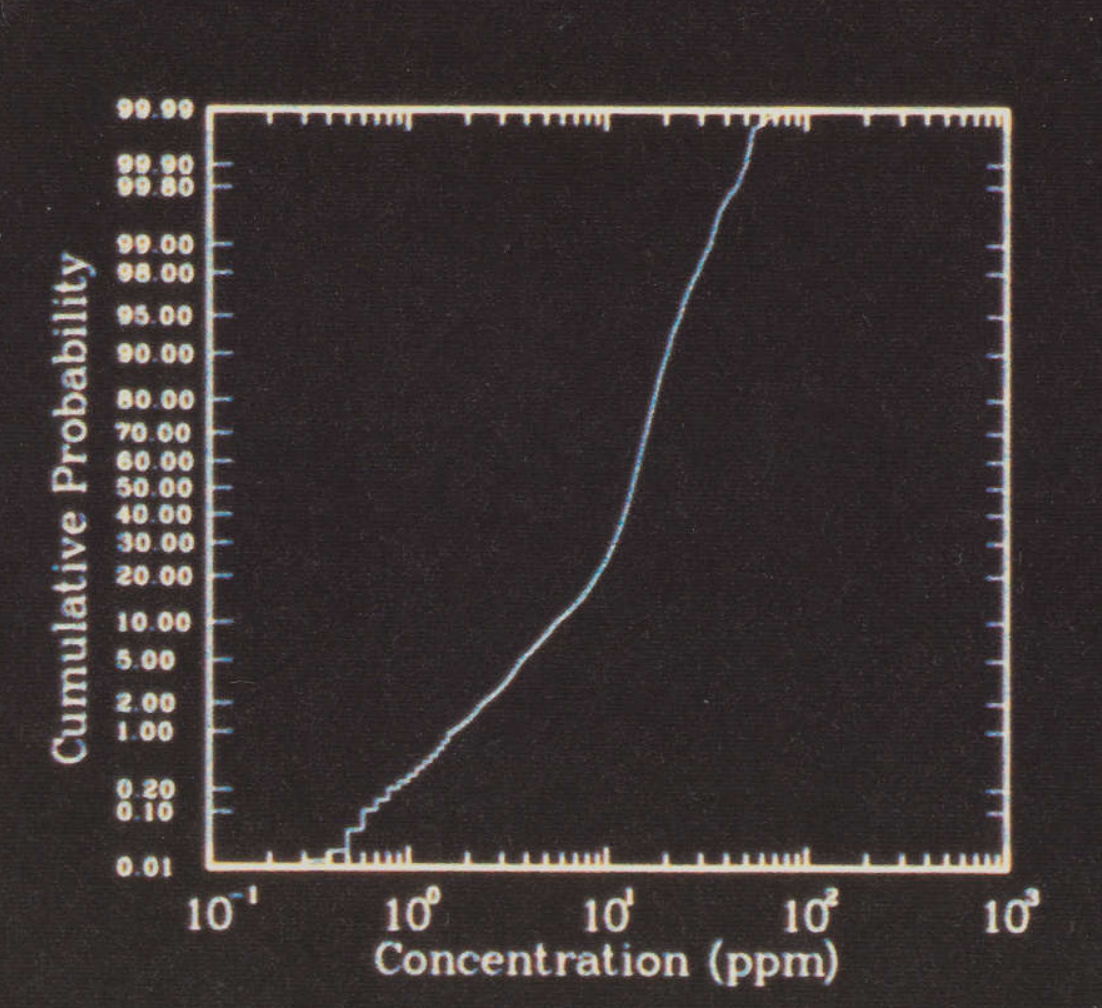

$13.56 \mathrm{ppm}$

$0.10 \mathrm{ppm}$

$13.50 \mathrm{ppm}$

$128.60 \mathrm{ppm}$

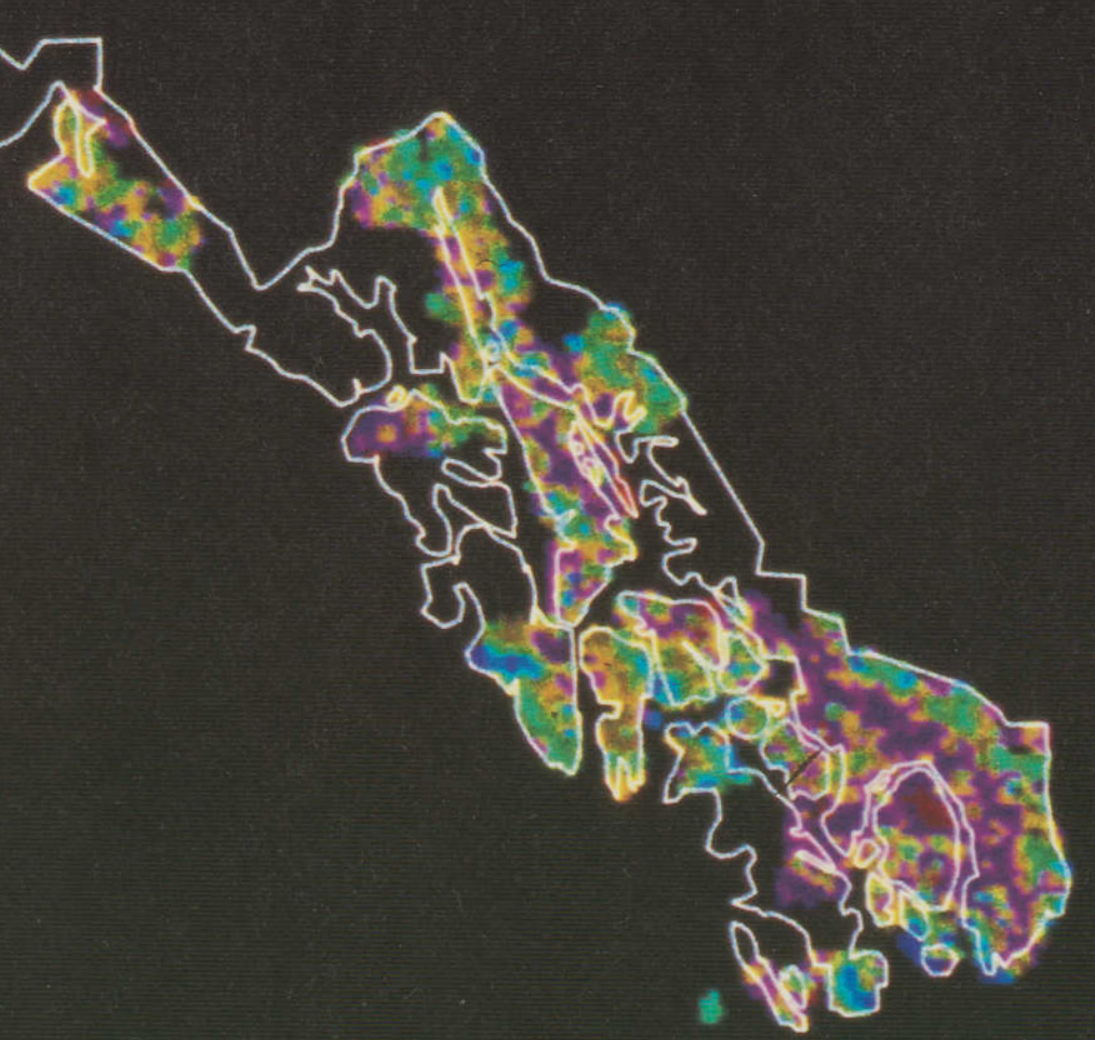


$-36-$

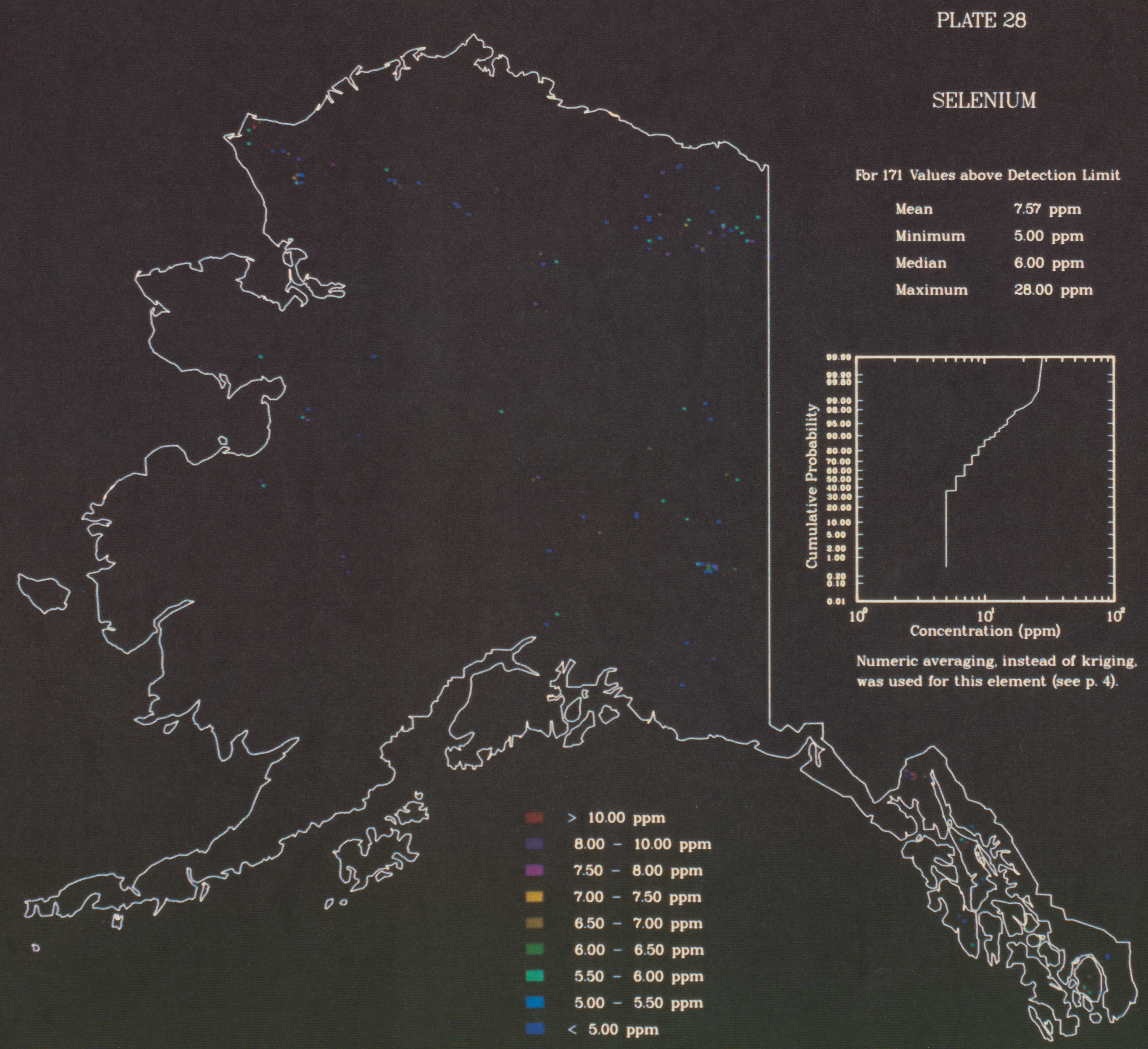


$-37-$

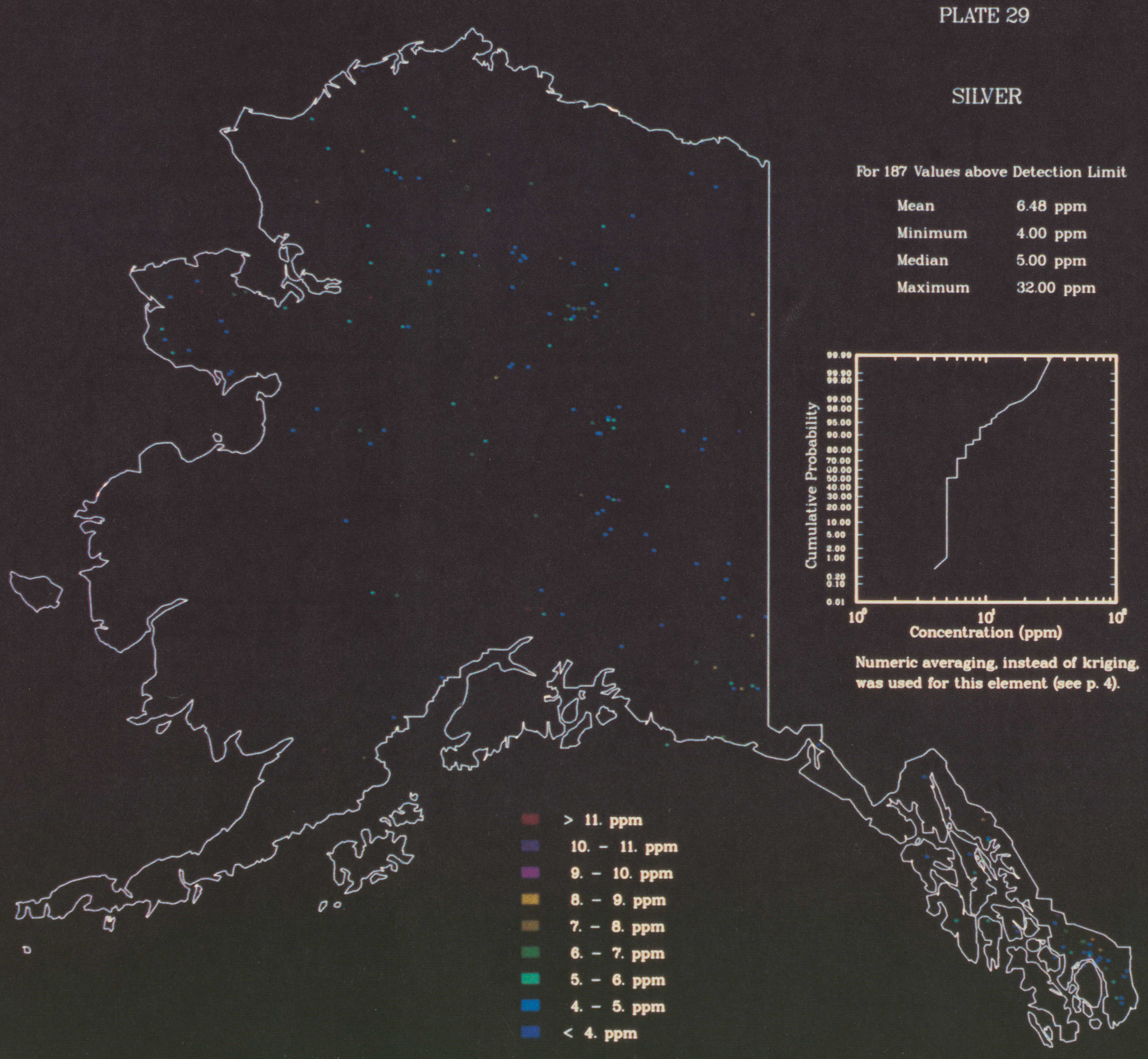


$-38-$

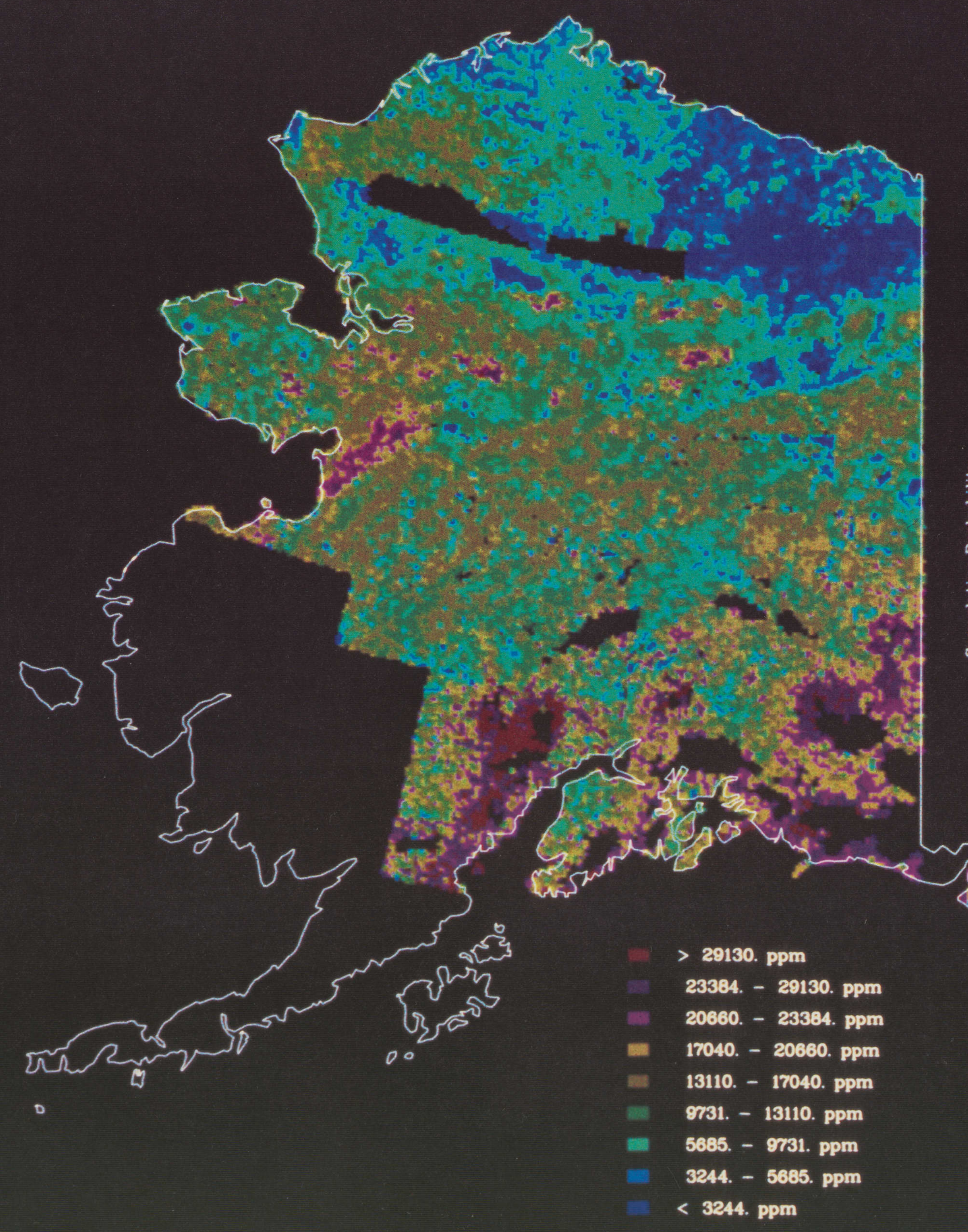

PLATE 30

SODIUM

For 61866 Values above Detection Limit

Mean

Minimum 11812.53 ppm

71.00 ppm

$11500.00 \mathrm{ppm}$

Maximum $160700.00 \mathrm{ppm}$
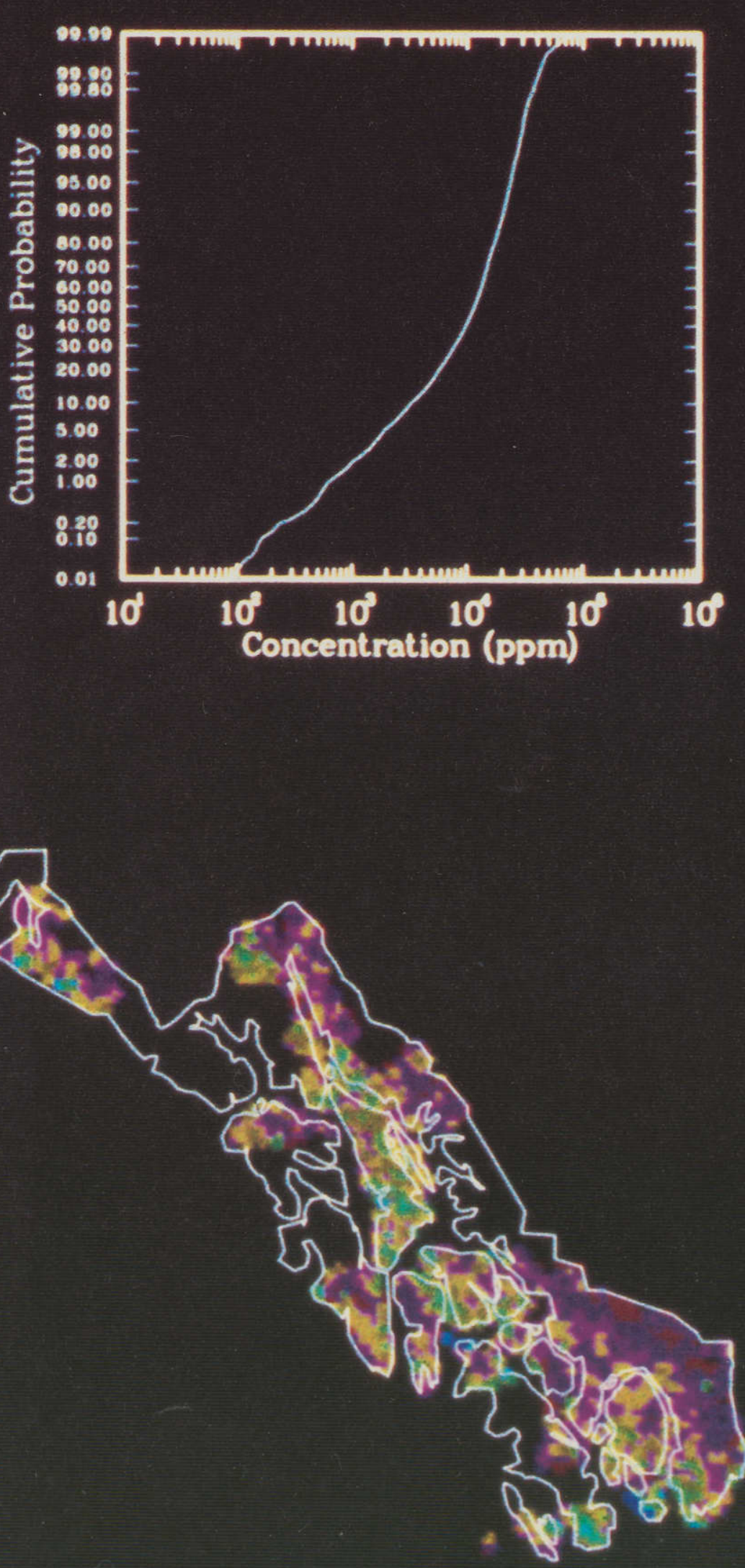
$-39-$

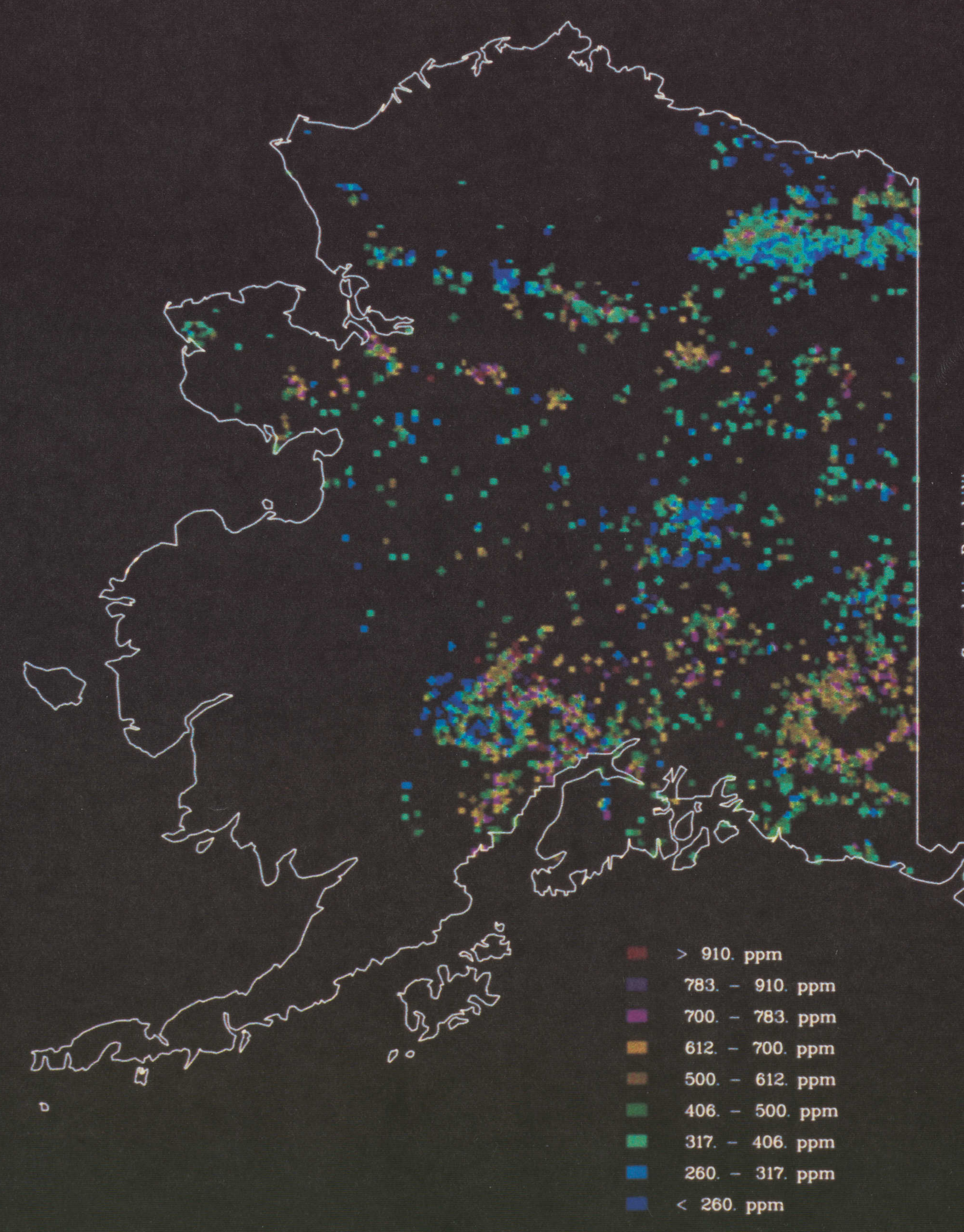

PLATE 31

STRONTIUM

For 3598 Values above Detection Limit

Mean $489.31 \mathrm{ppm}$

Minimum $40.00 \mathrm{ppm}$

Median $455.00 \mathrm{ppm}$

Maximum $5478.00 \mathrm{ppm}$
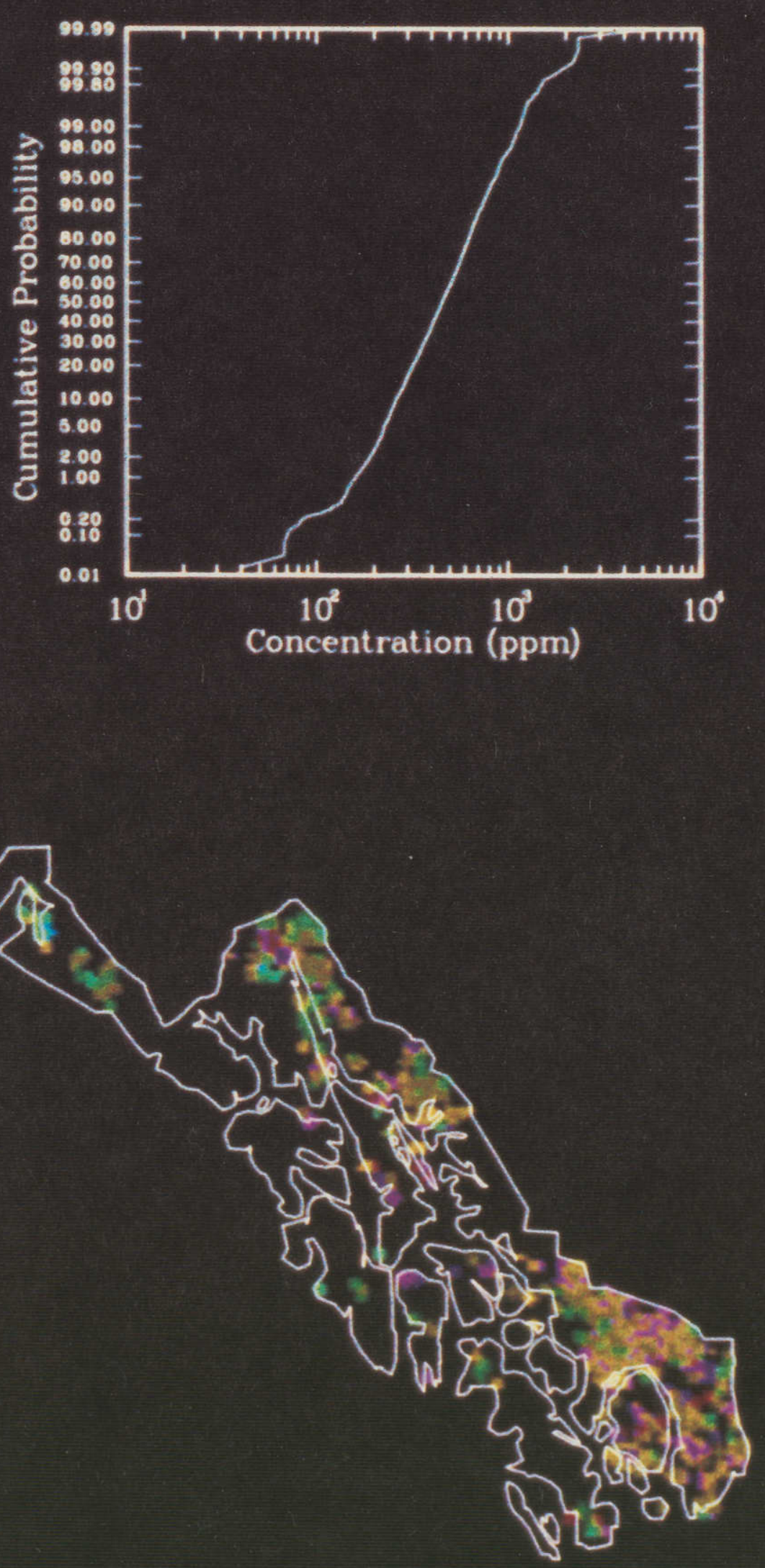
$-40-$

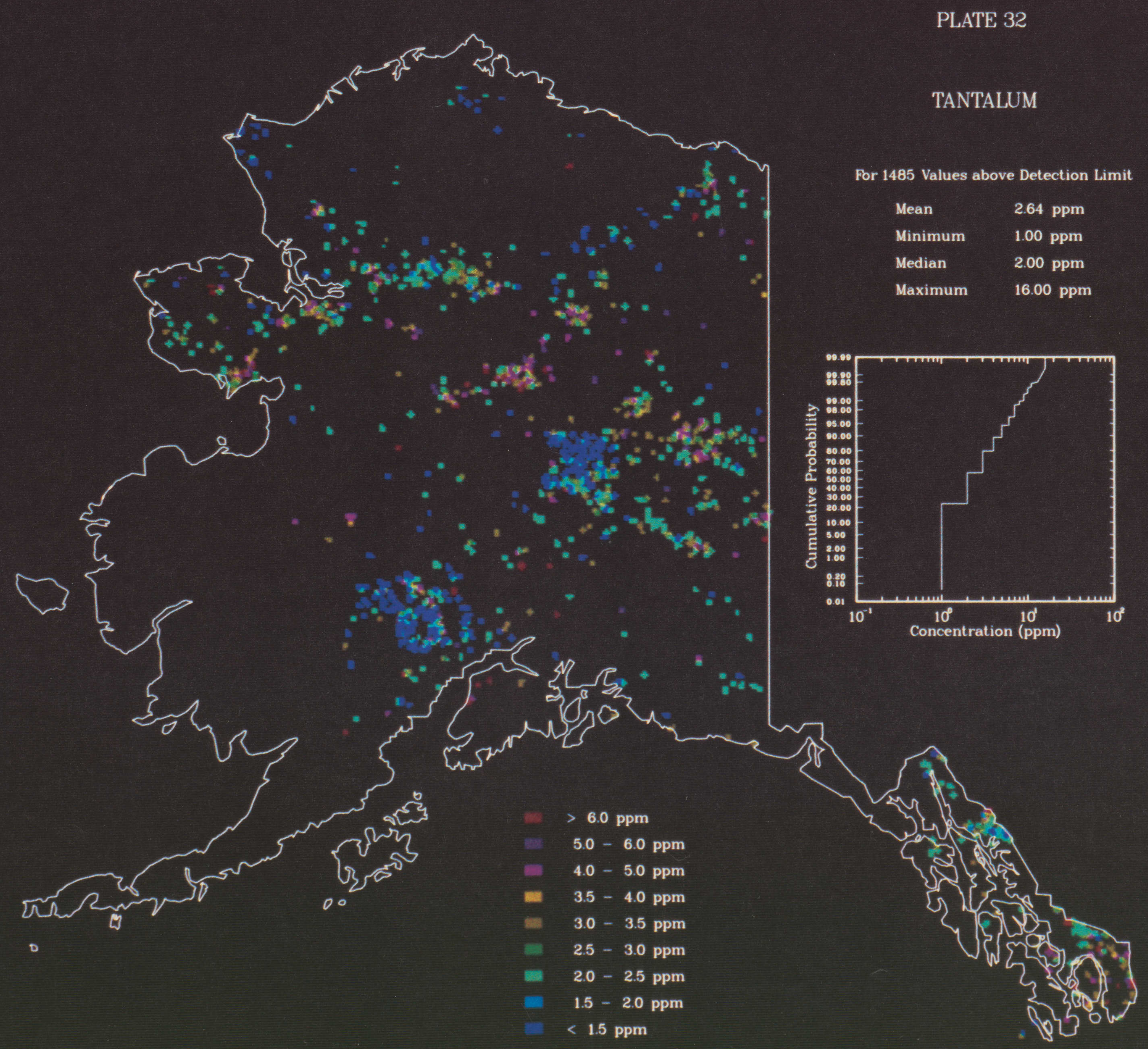


$-41-$

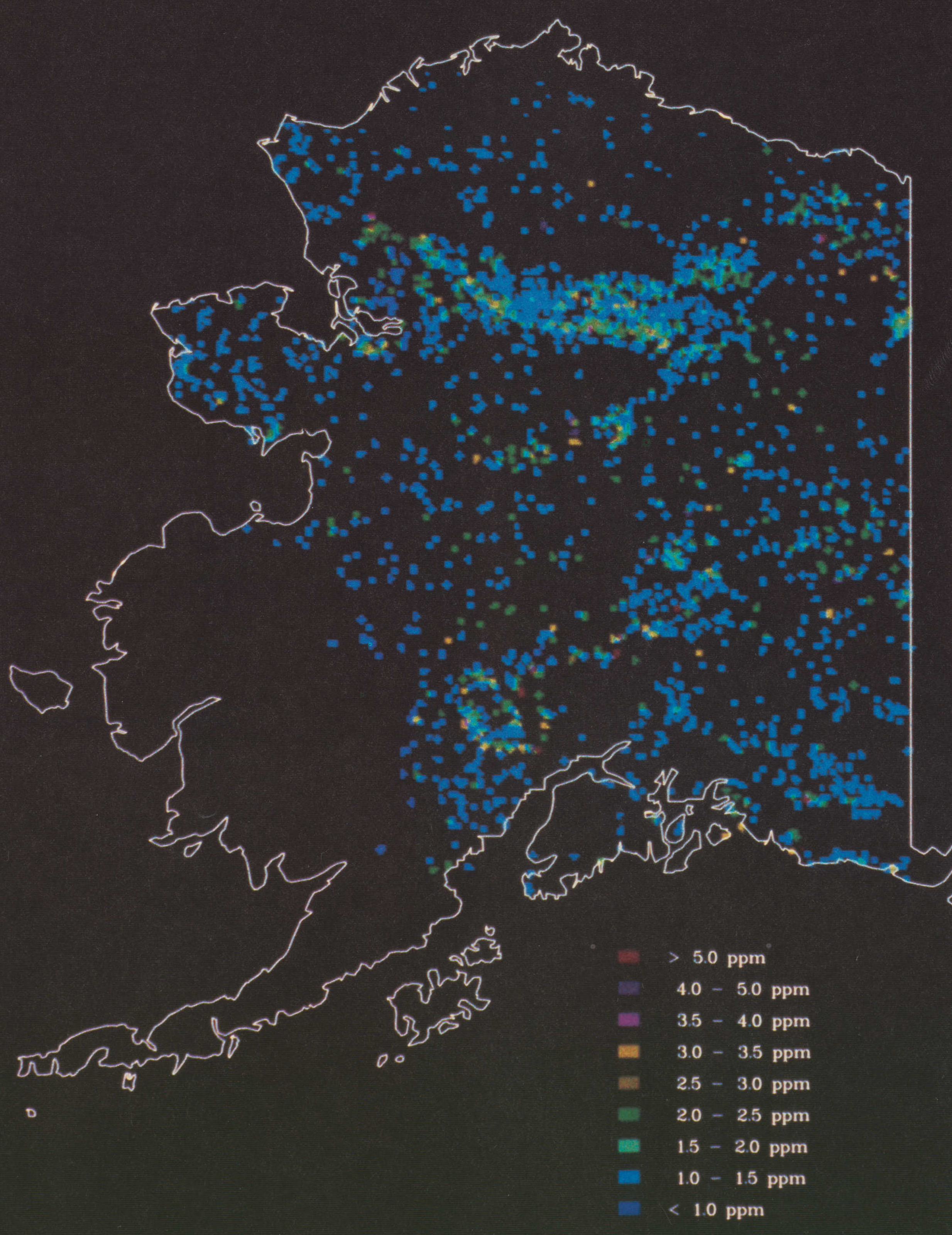

PLATE 33

TERBIUM

For 2952 Values above Detection Limit

$\begin{array}{ll}\text { Mean } & 1.36 \mathrm{ppm} \\ \text { Minimum } & 1.00 \mathrm{ppm} \\ \text { Median } & 1.00 \mathrm{ppm} \\ \text { Maximum } & 12.00 \mathrm{ppm}\end{array}$

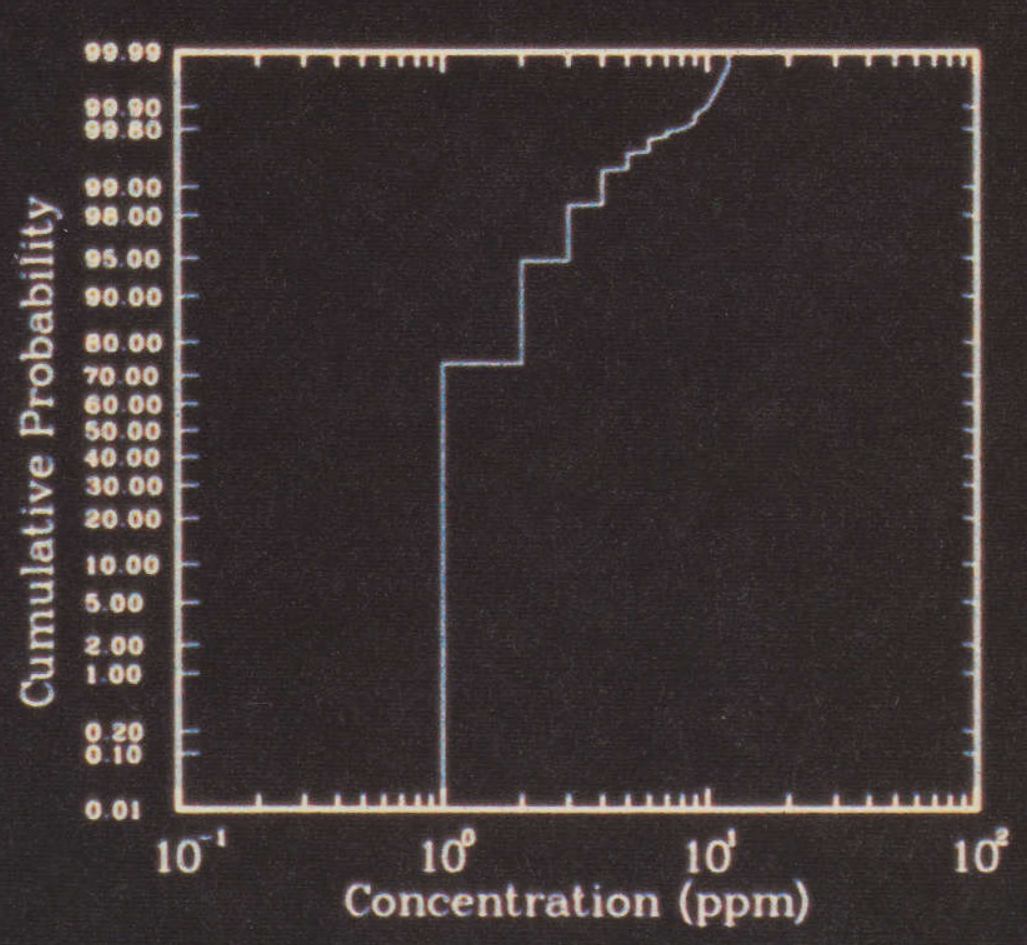




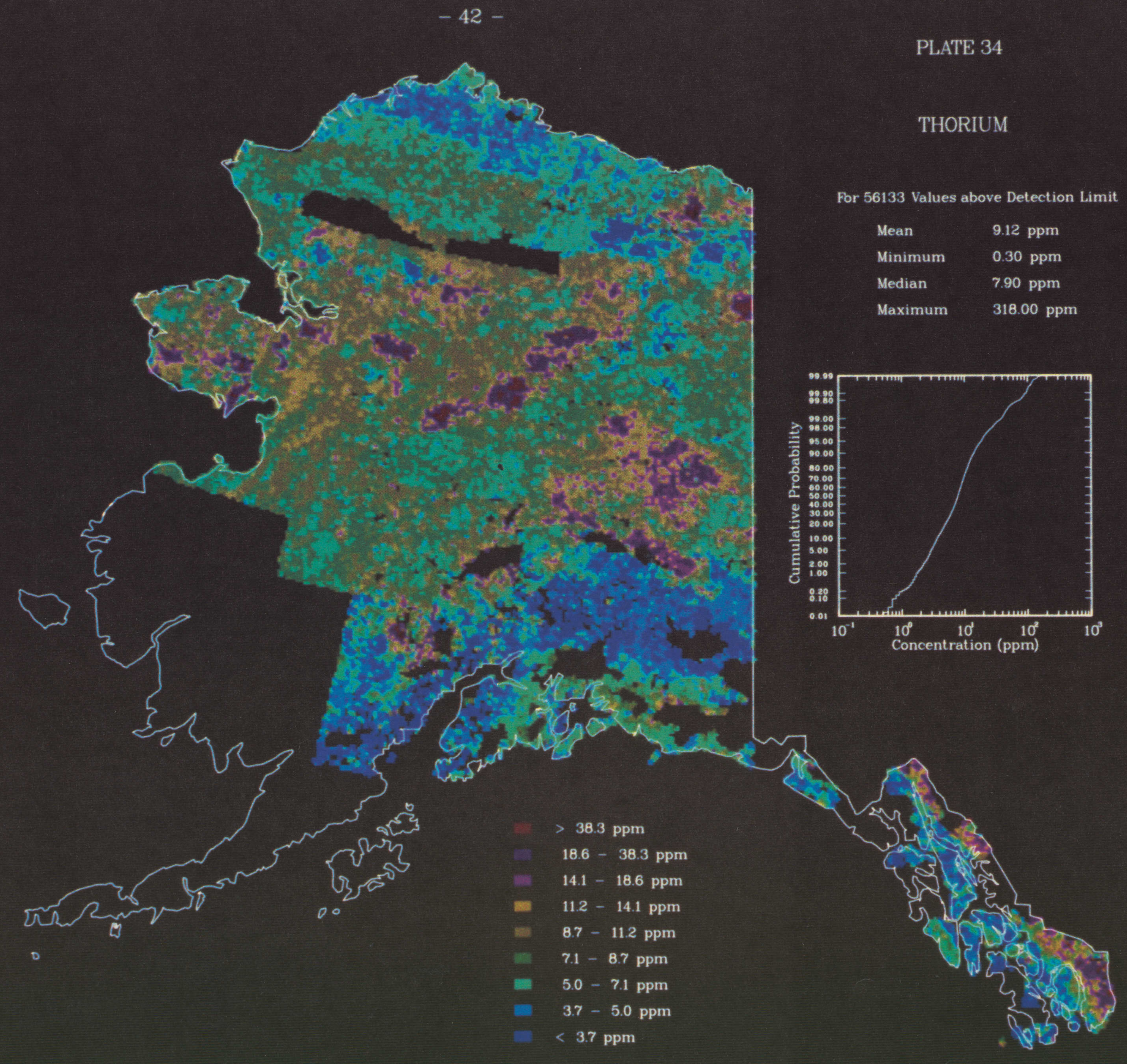


$-43-$

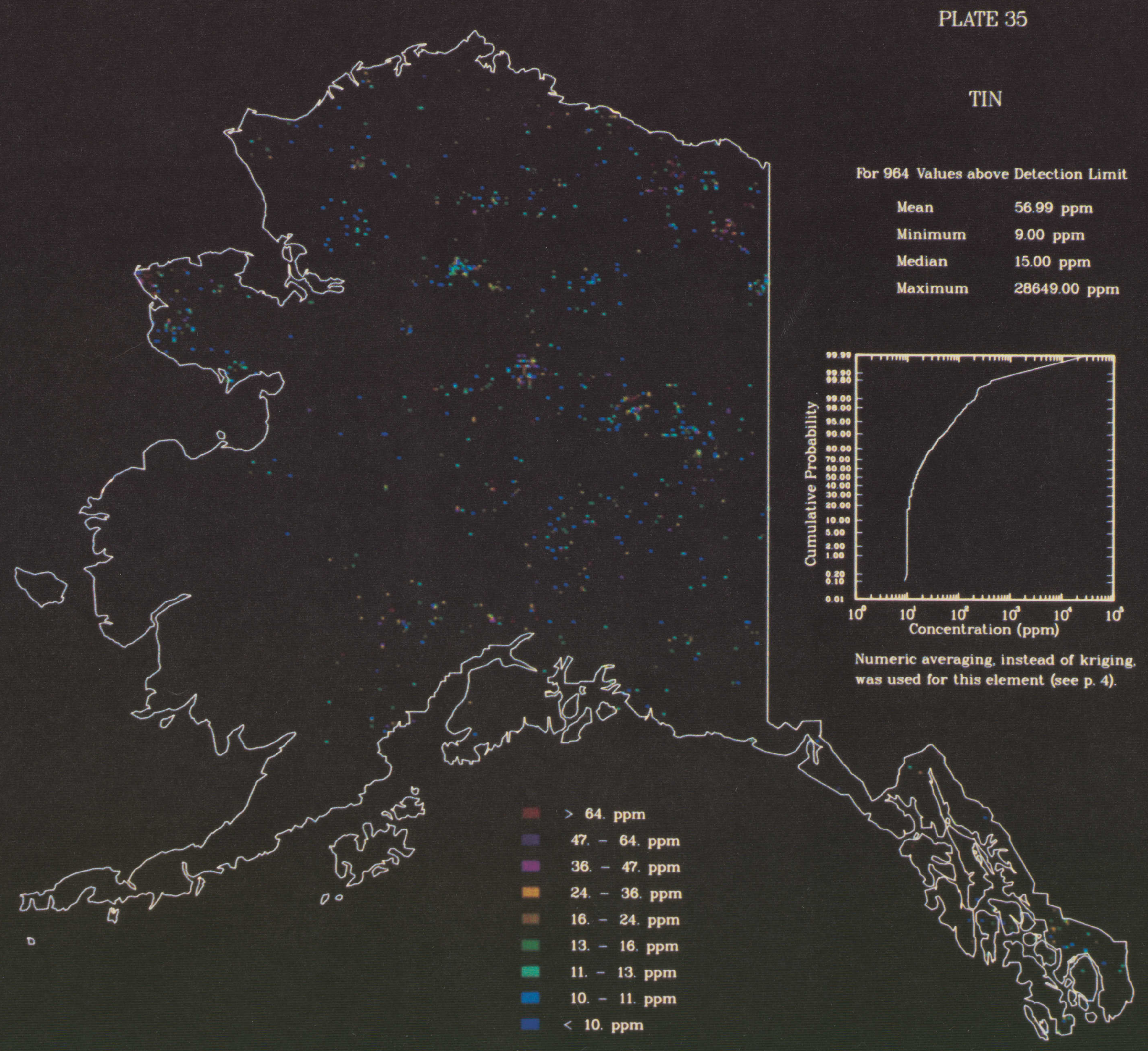


$-44-$

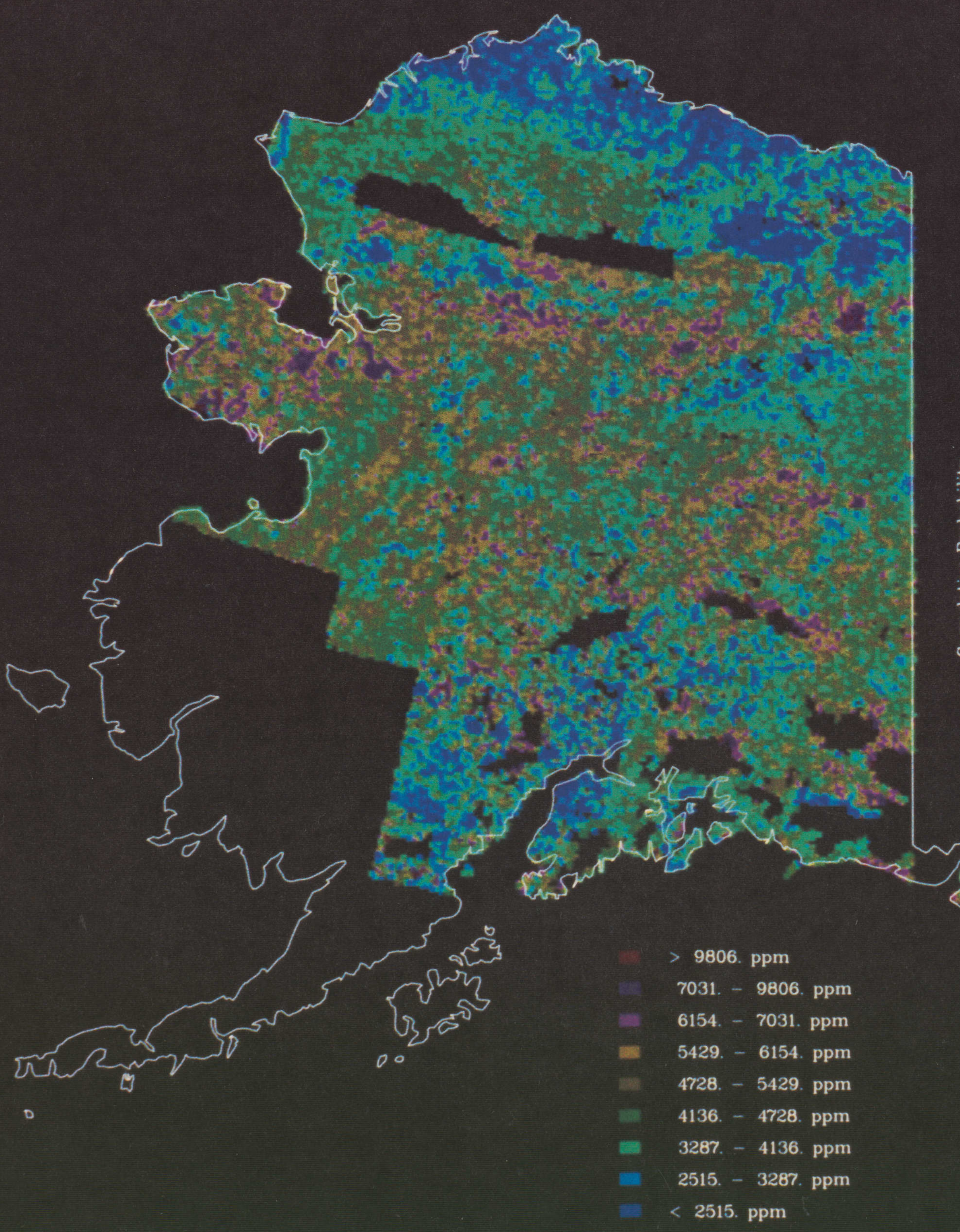

PLATE 36

TITANIUM

For 57402 Values above Detection Limit

Mean

Minimum

$4478.35 \mathrm{ppm}$

$14.00 \mathrm{ppm}$

Median

$4441.00 \mathrm{ppm}$

Maximum

$99998.00 \mathrm{ppm}$

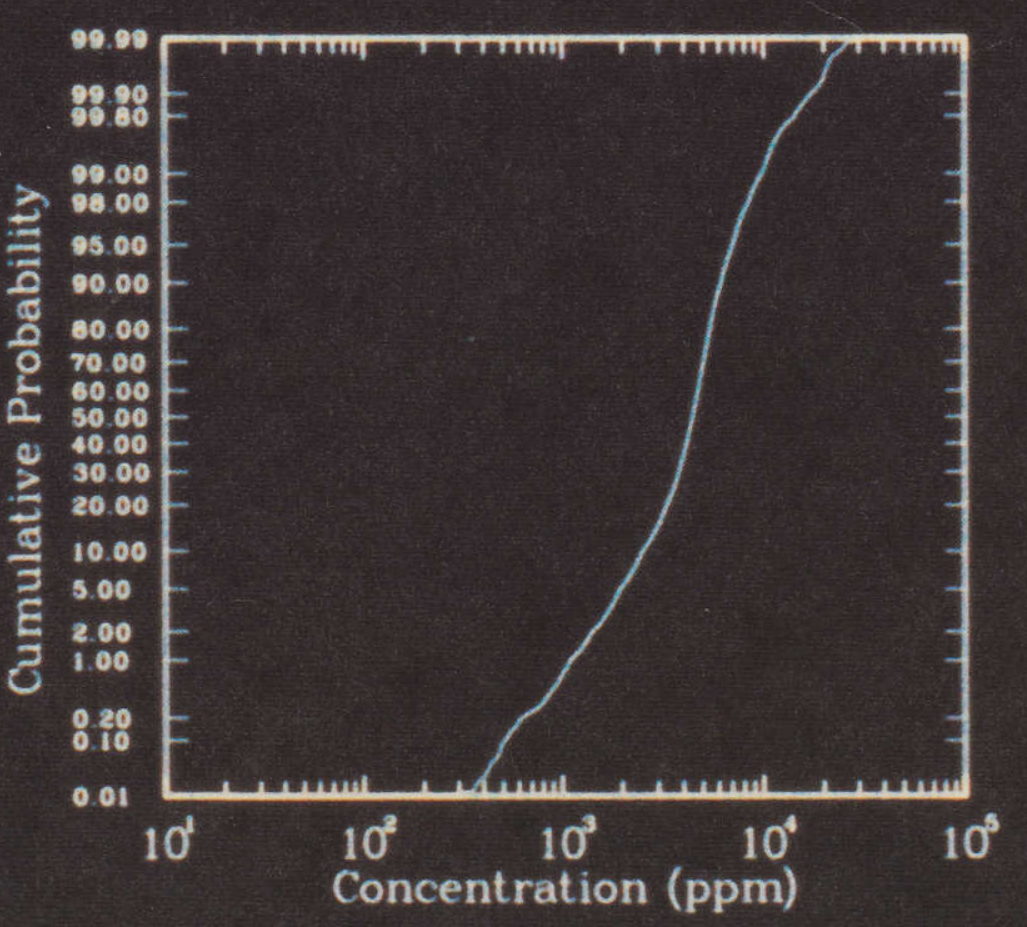

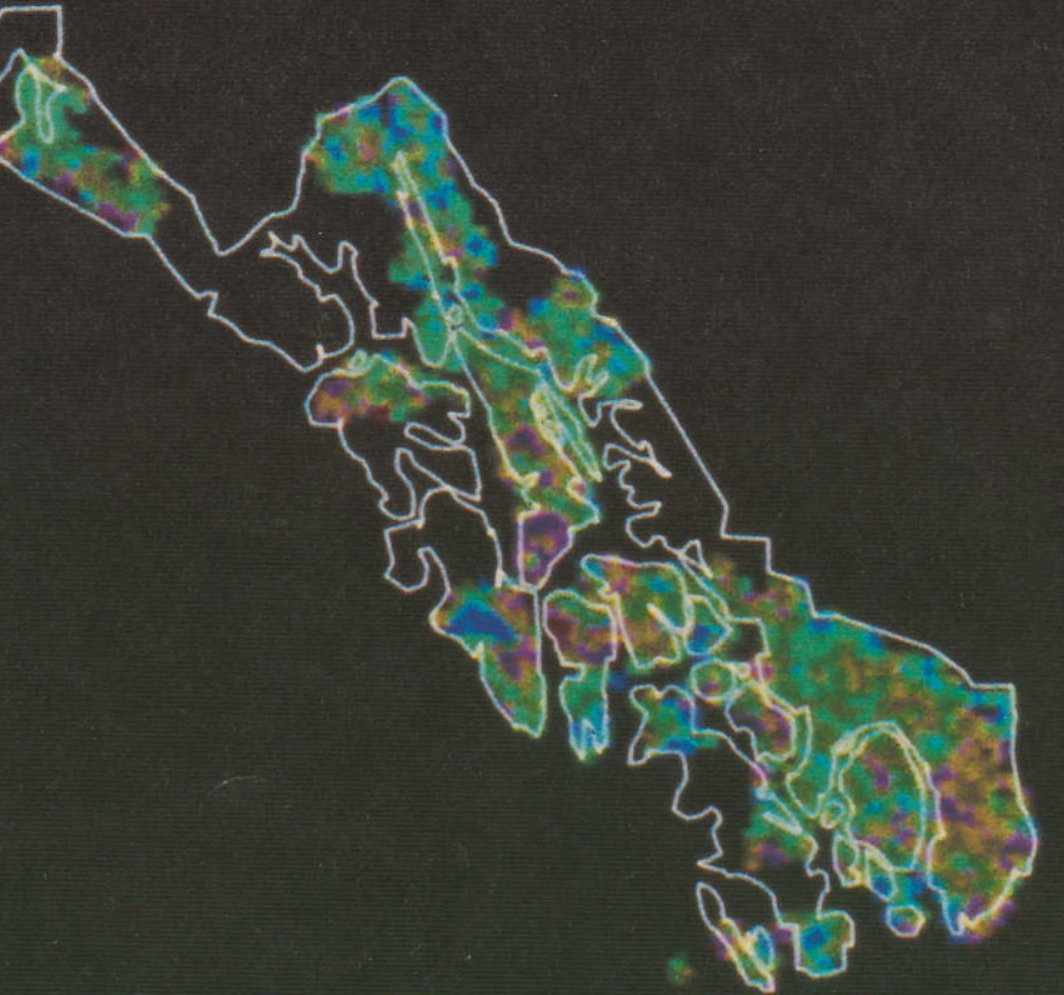




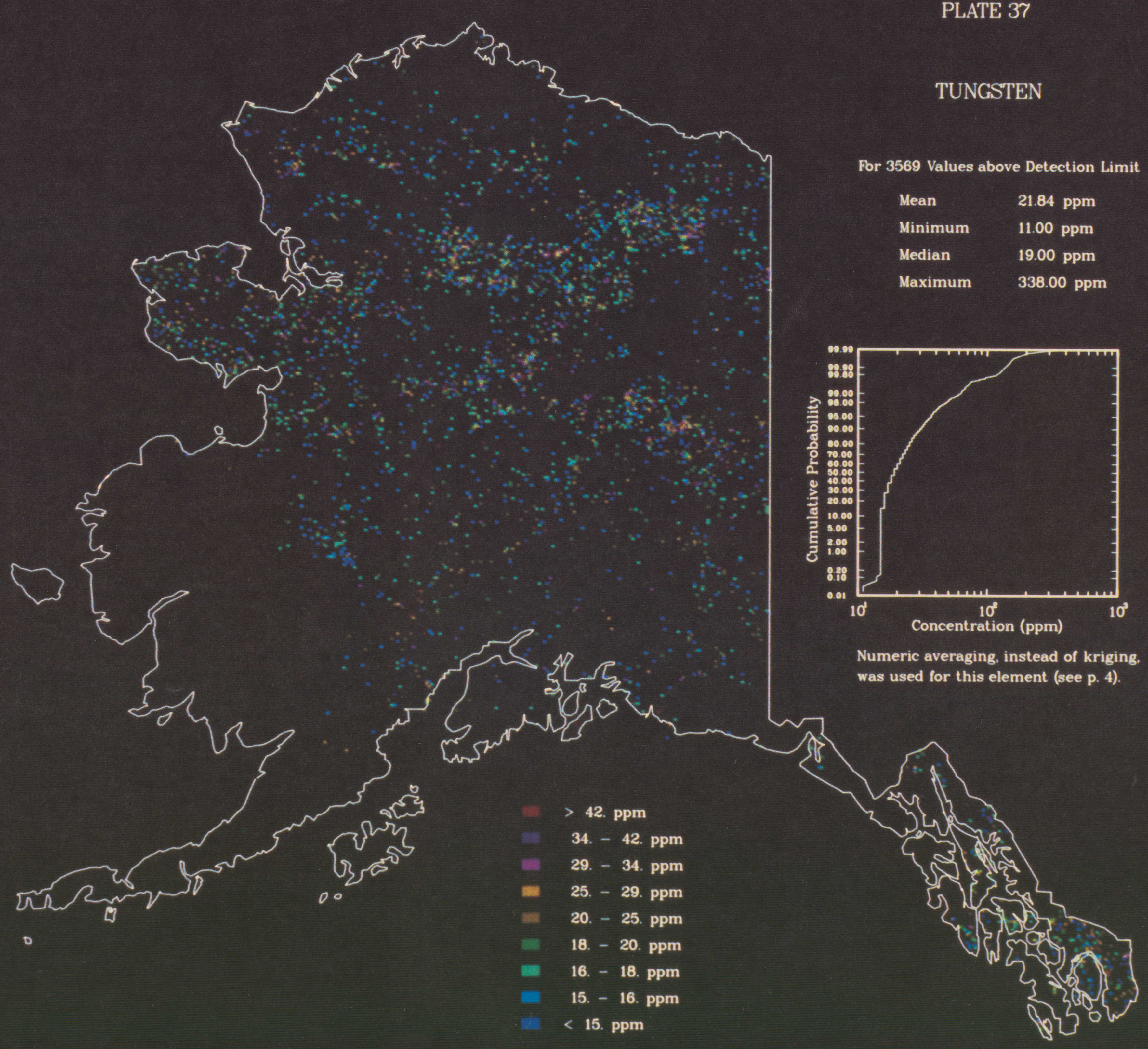


$-46-$

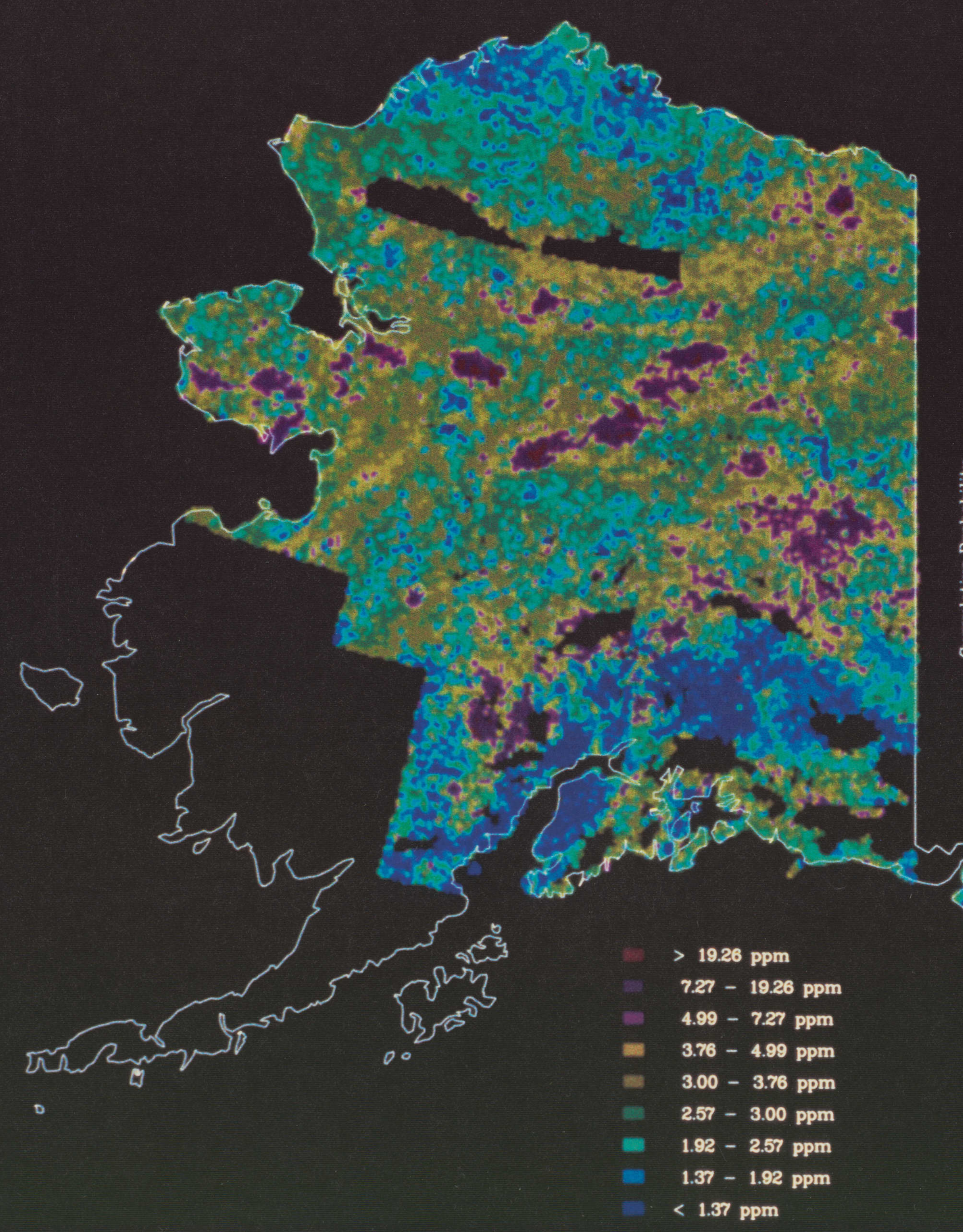

PLATE 38

URANIUM

For 61909 Values above Detection Limit

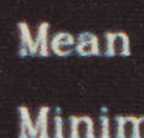
$3.45 \mathrm{ppm}$

Minimum $0.02 \mathrm{ppm}$

Median $2.78 \mathrm{ppm}$

Maximum $334.90 \mathrm{ppm}$

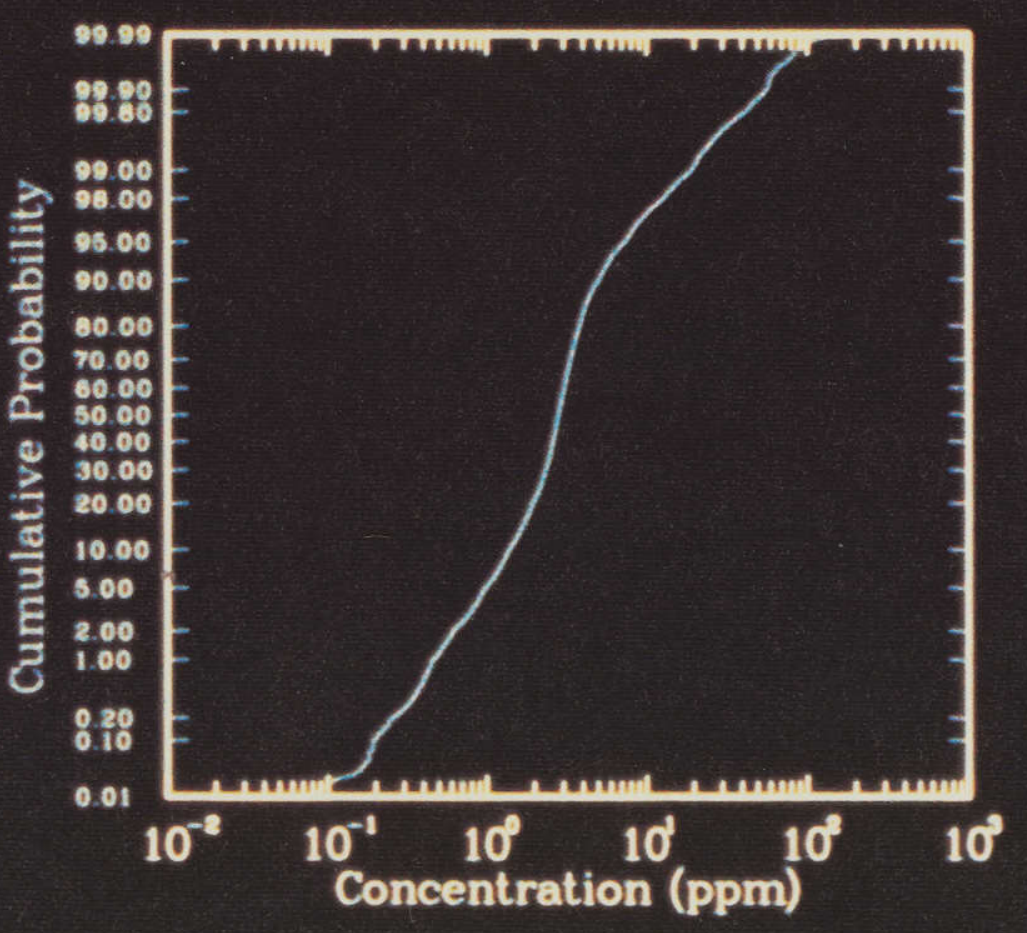

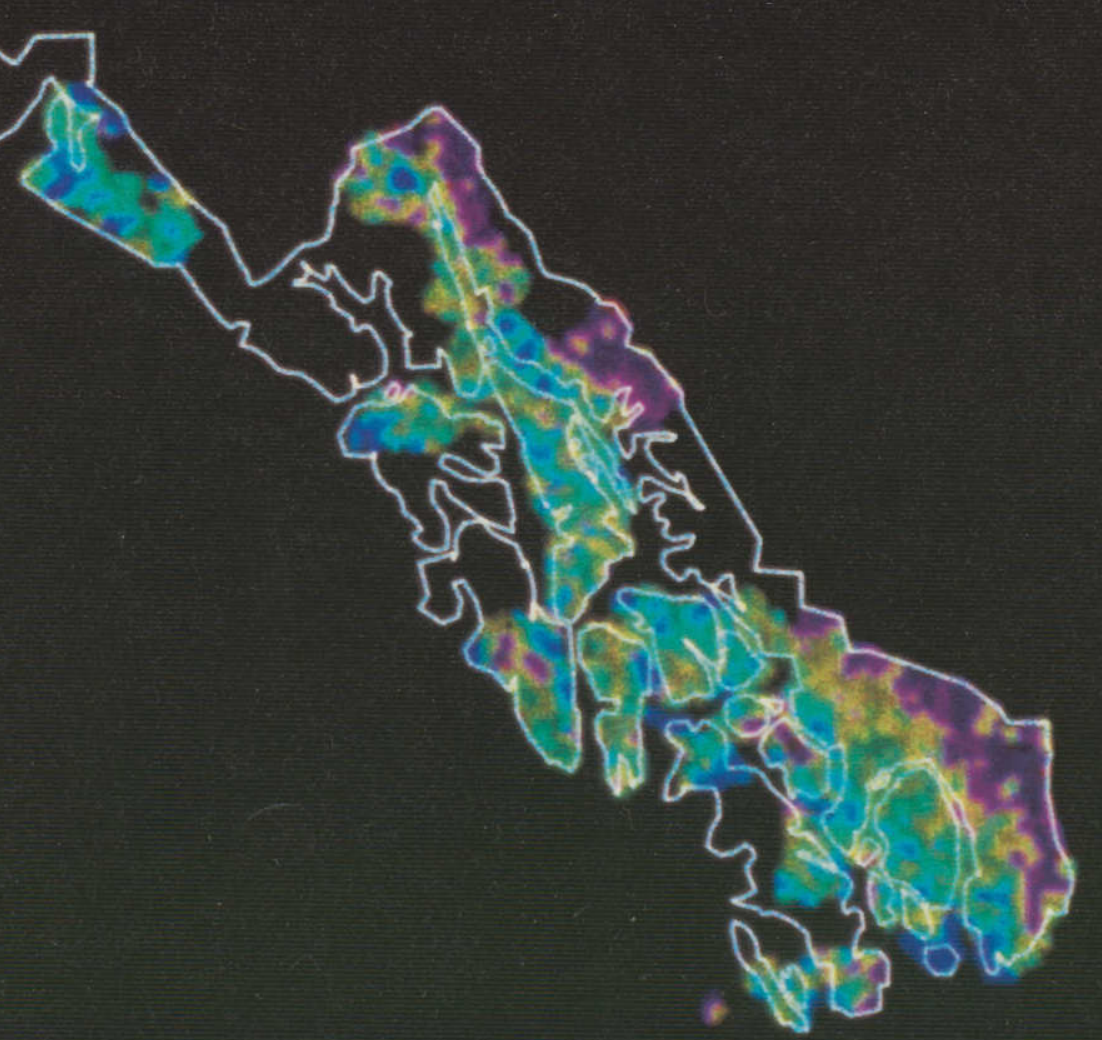




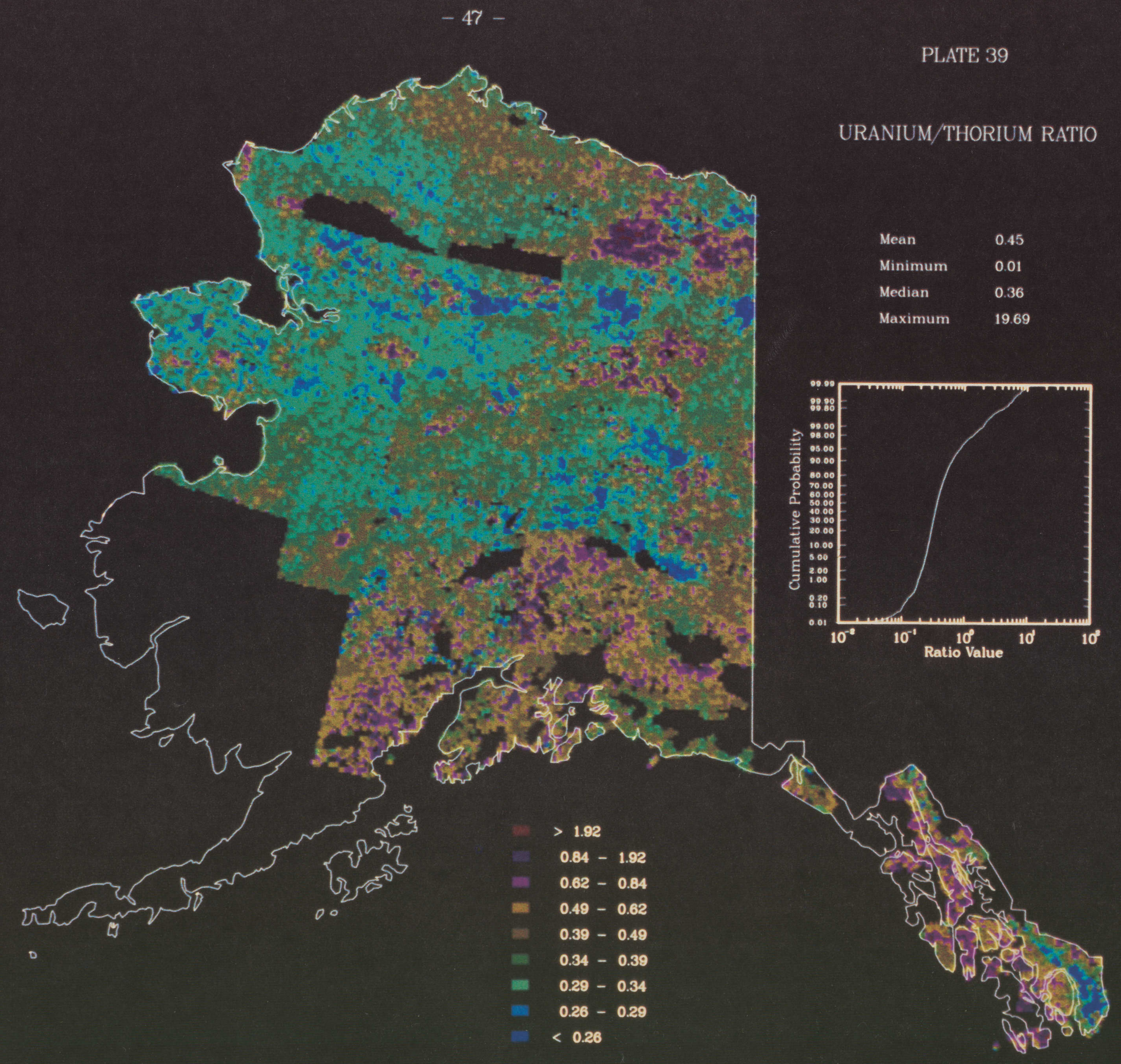




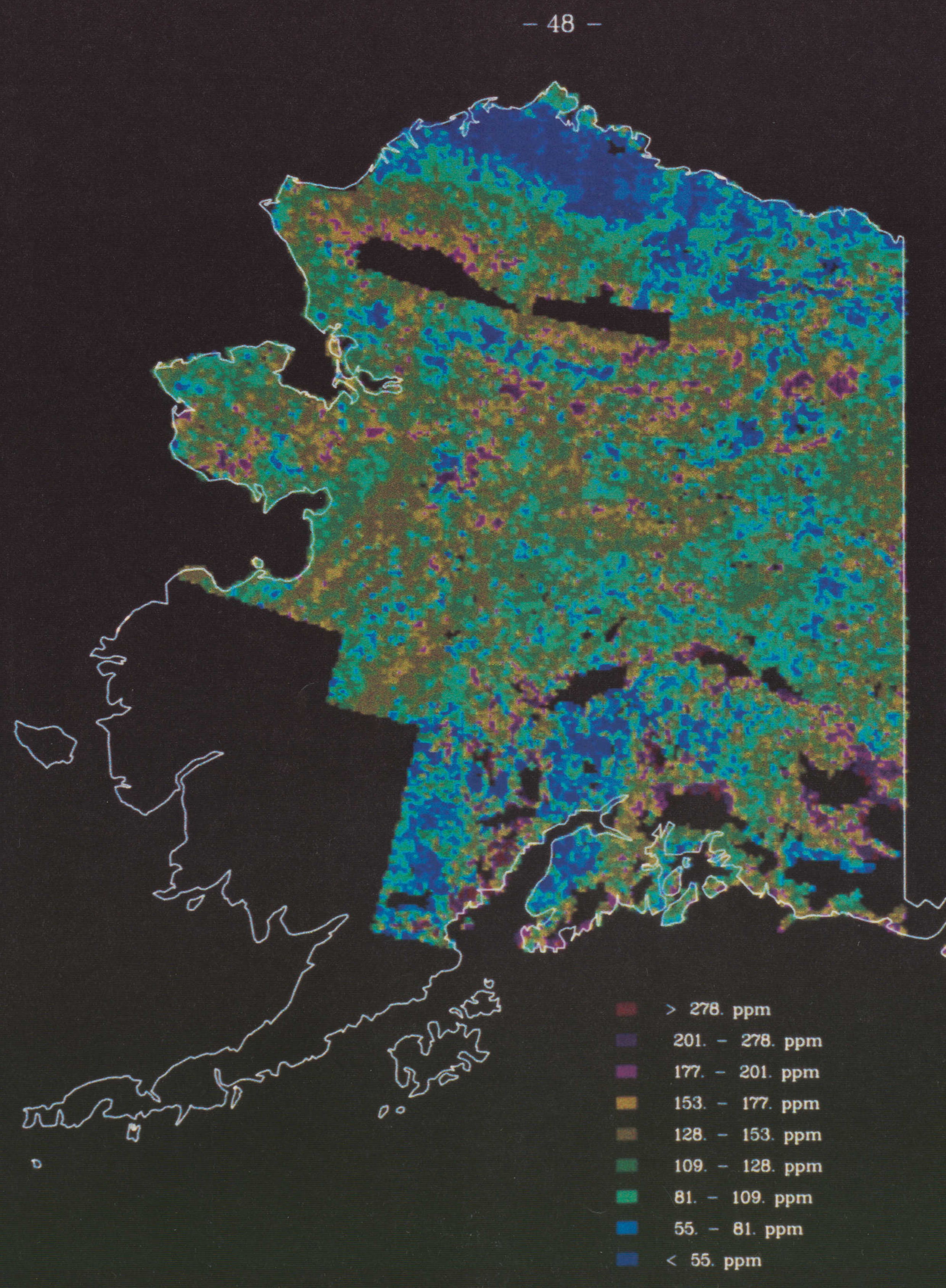

PLATE 40

VANADIUM

For 60750 Values above Detection Limit

Mean $120.48 \mathrm{ppm}$

Minimum $2.00 \mathrm{ppm}$

Median $\quad 119.00 \mathrm{ppm}$

Maximum $2003.00 \mathrm{ppm}$
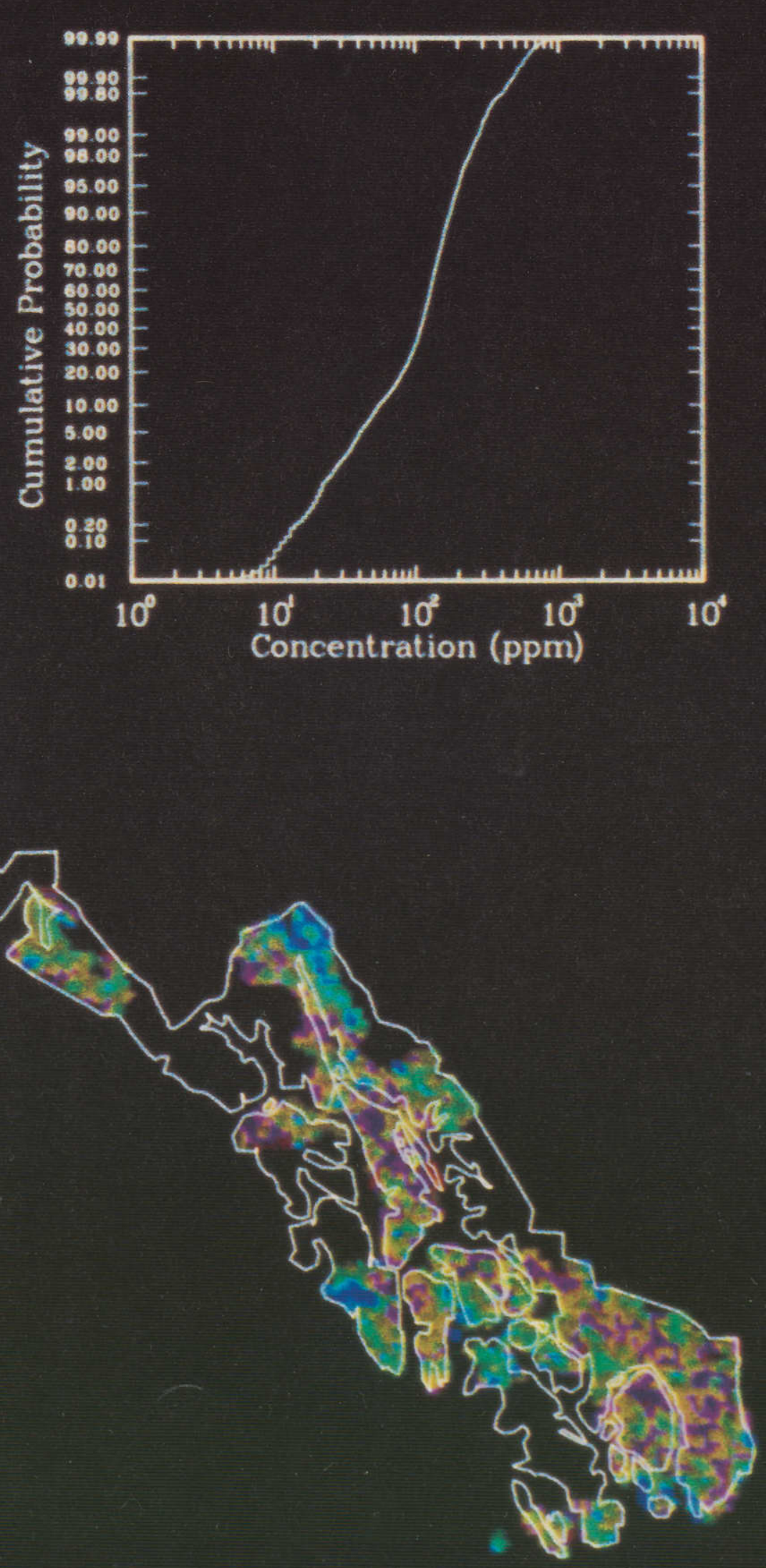
$-49-$

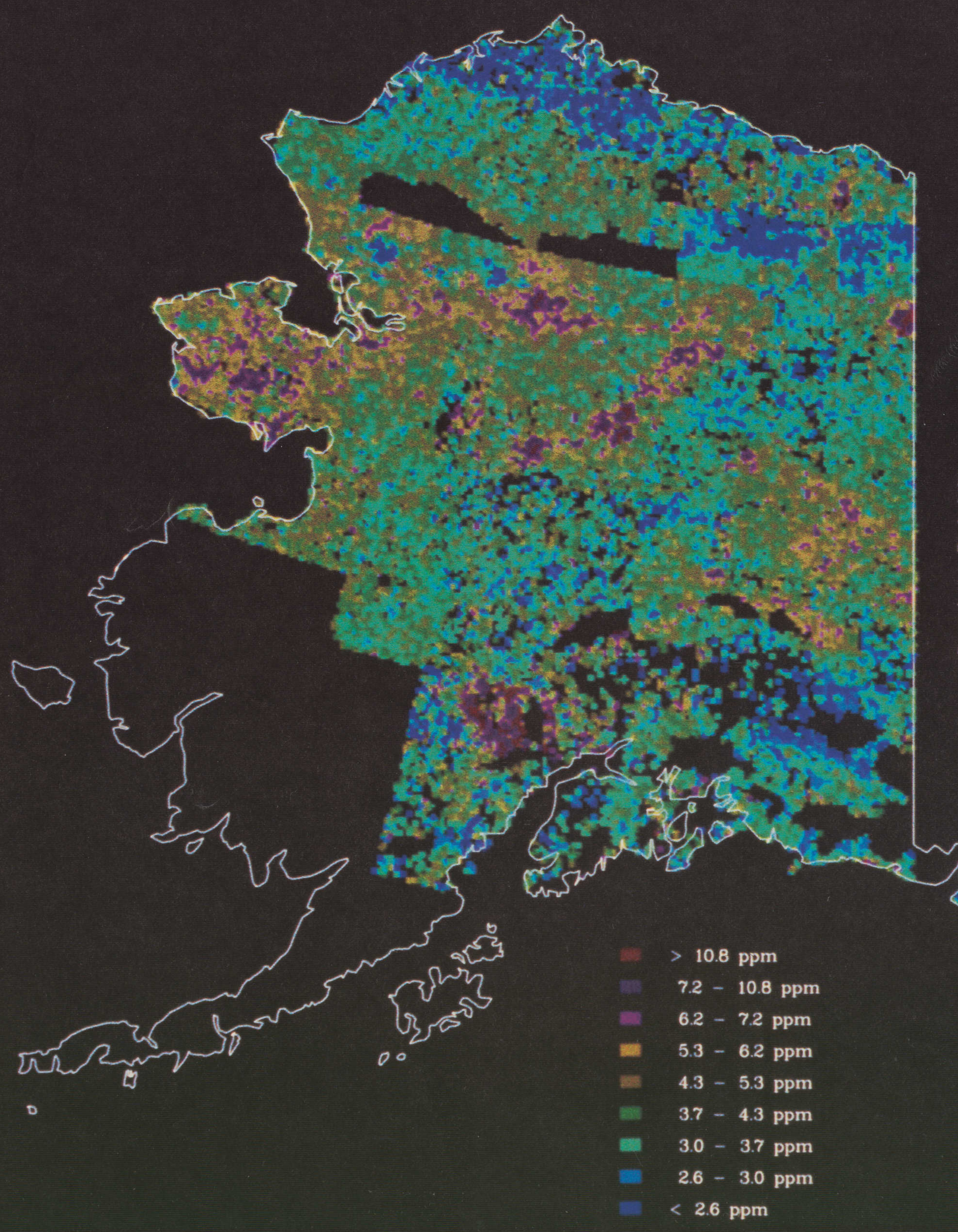

PLATE 41

YTTERBIUM

For 37692 Values above Detection Limit

$\begin{array}{ll}\text { Mean } & 4.34 \mathrm{ppm} \\ \text { Minimum } & 0.20 \mathrm{ppm} \\ \text { Median } & 4.00 \mathrm{ppm} \\ \text { Maximum } & 90.40 \mathrm{ppm}\end{array}$

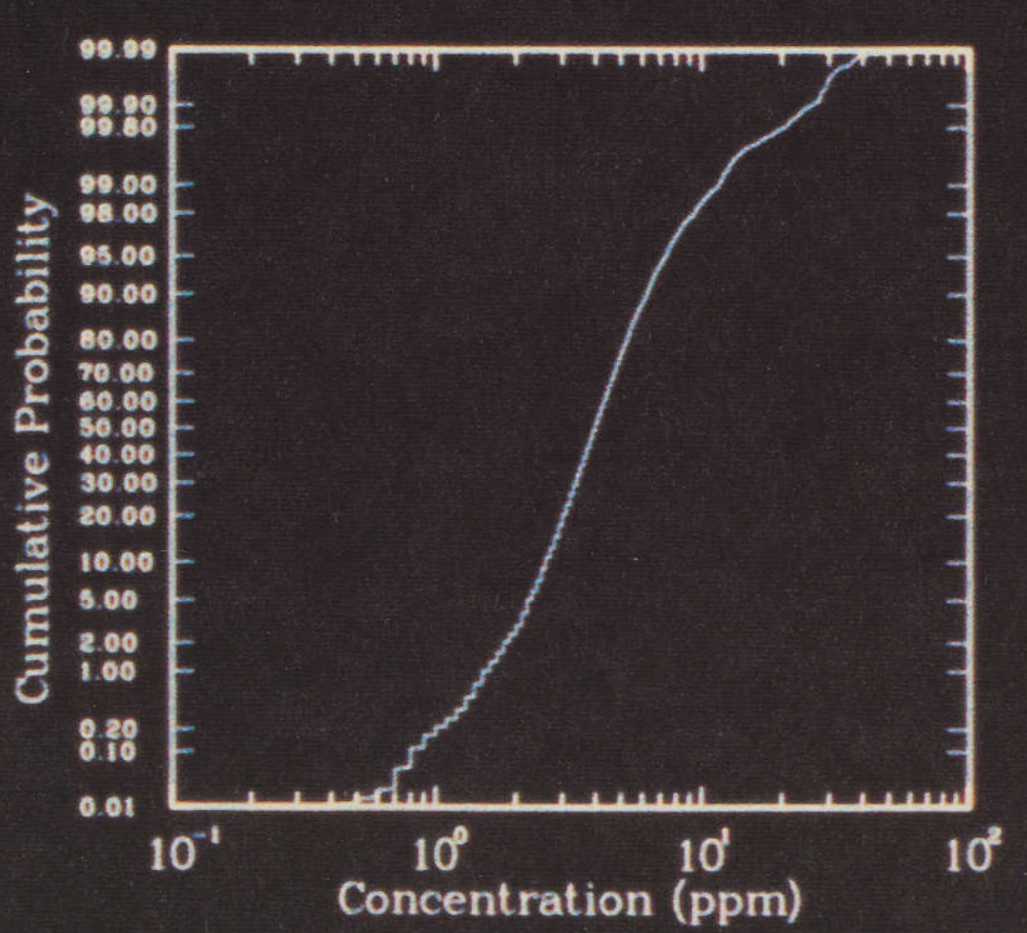

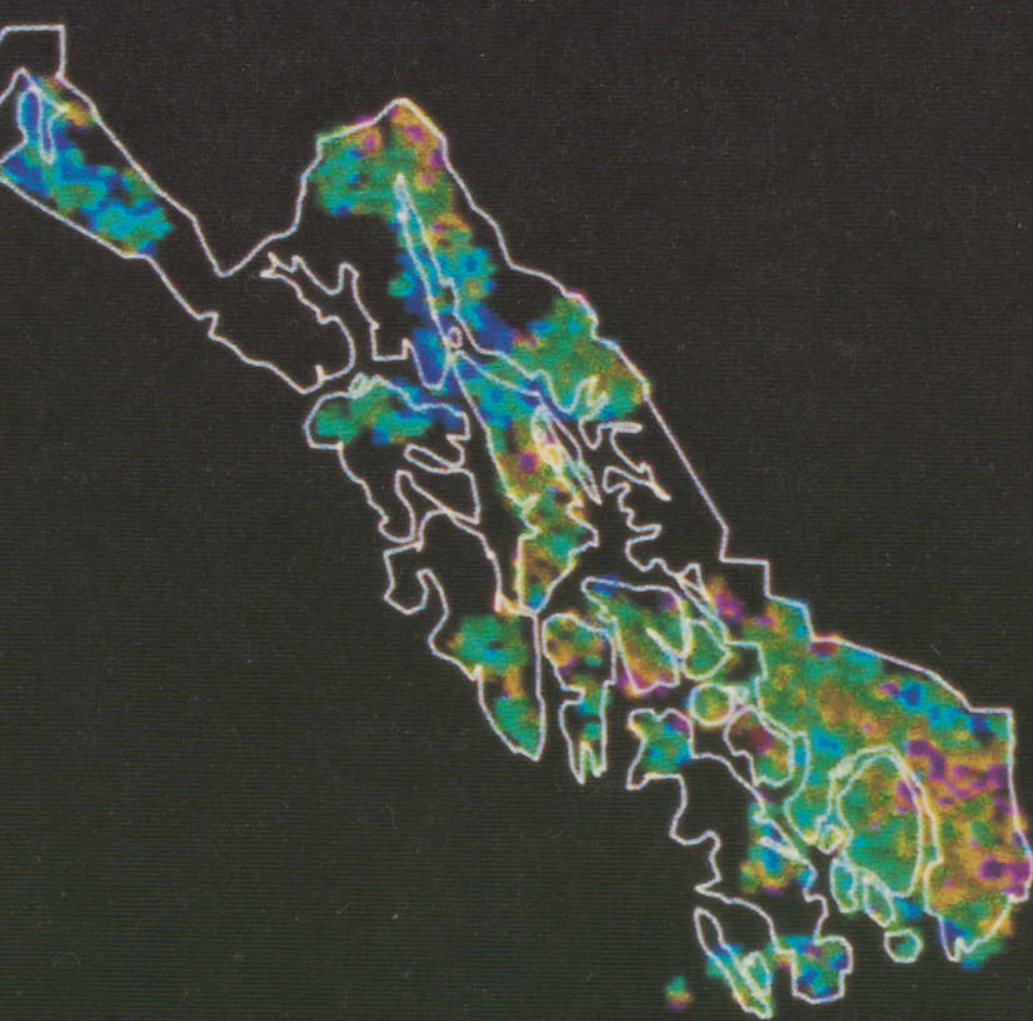




$$
-50-
$$

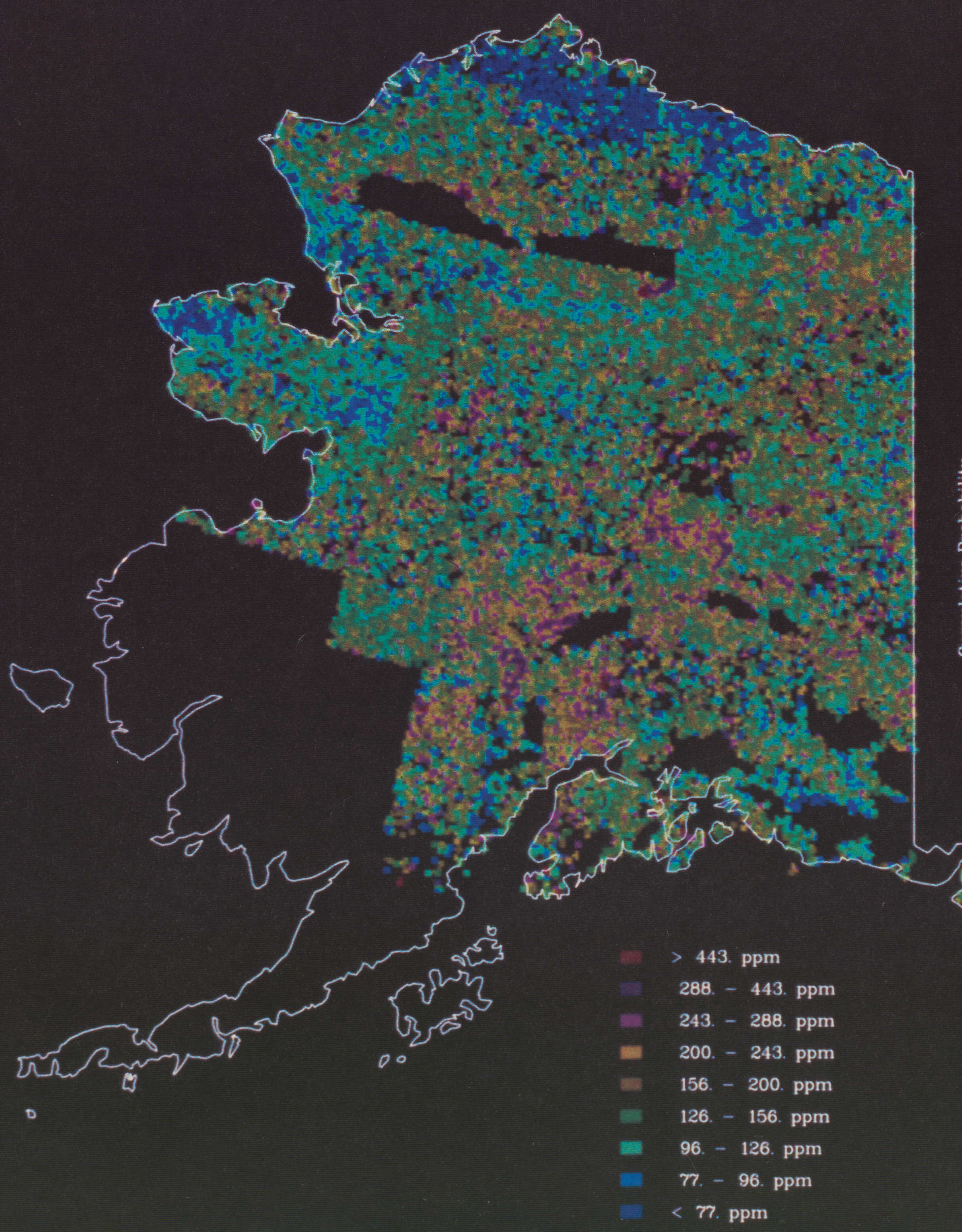

PLATE 42

ZINC

For 28739 Values above Detection Limit
Mean
Minimum
$157.20 \mathrm{ppm}$
ppm
Maximum
$4695.00 \mathrm{ppm}$
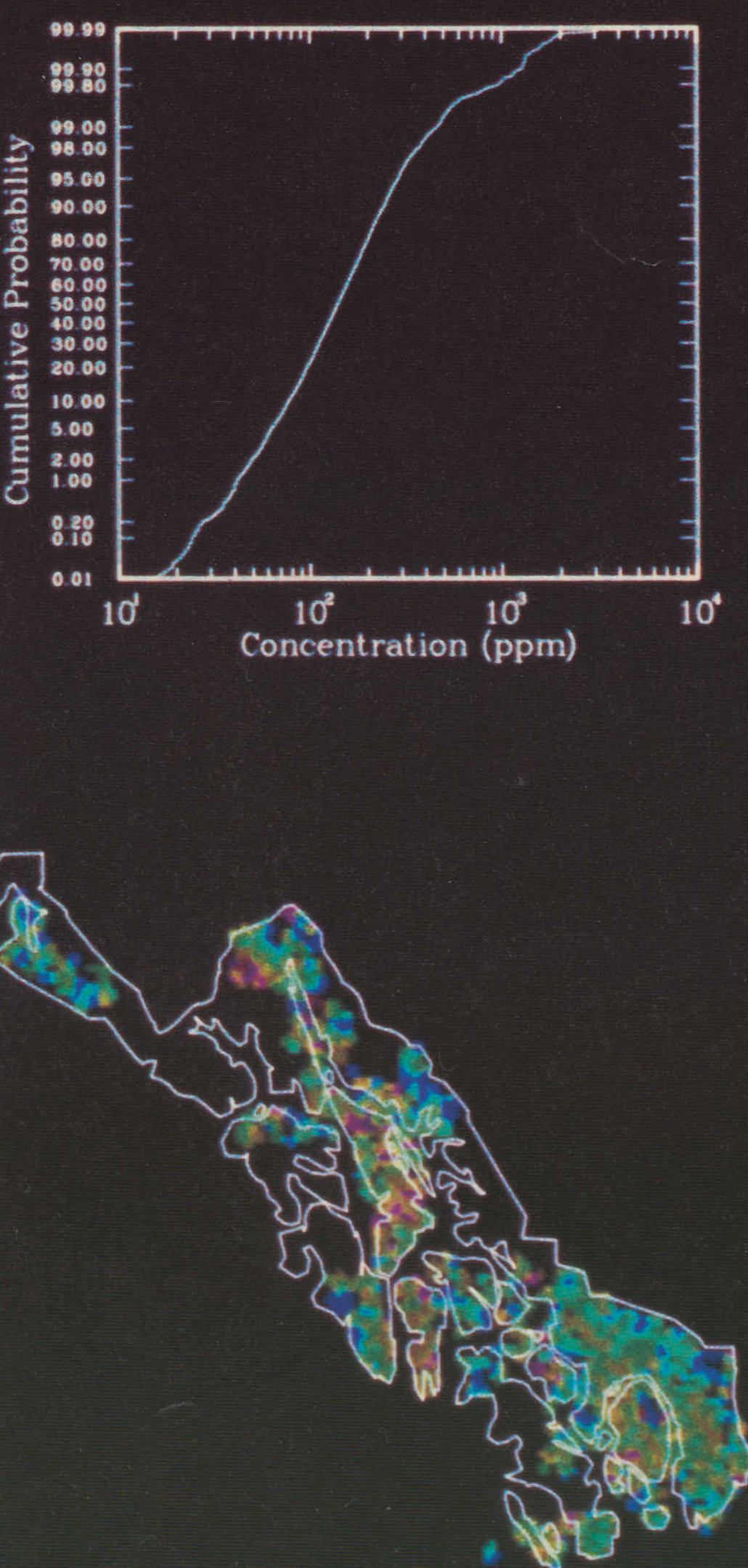
$-51-$

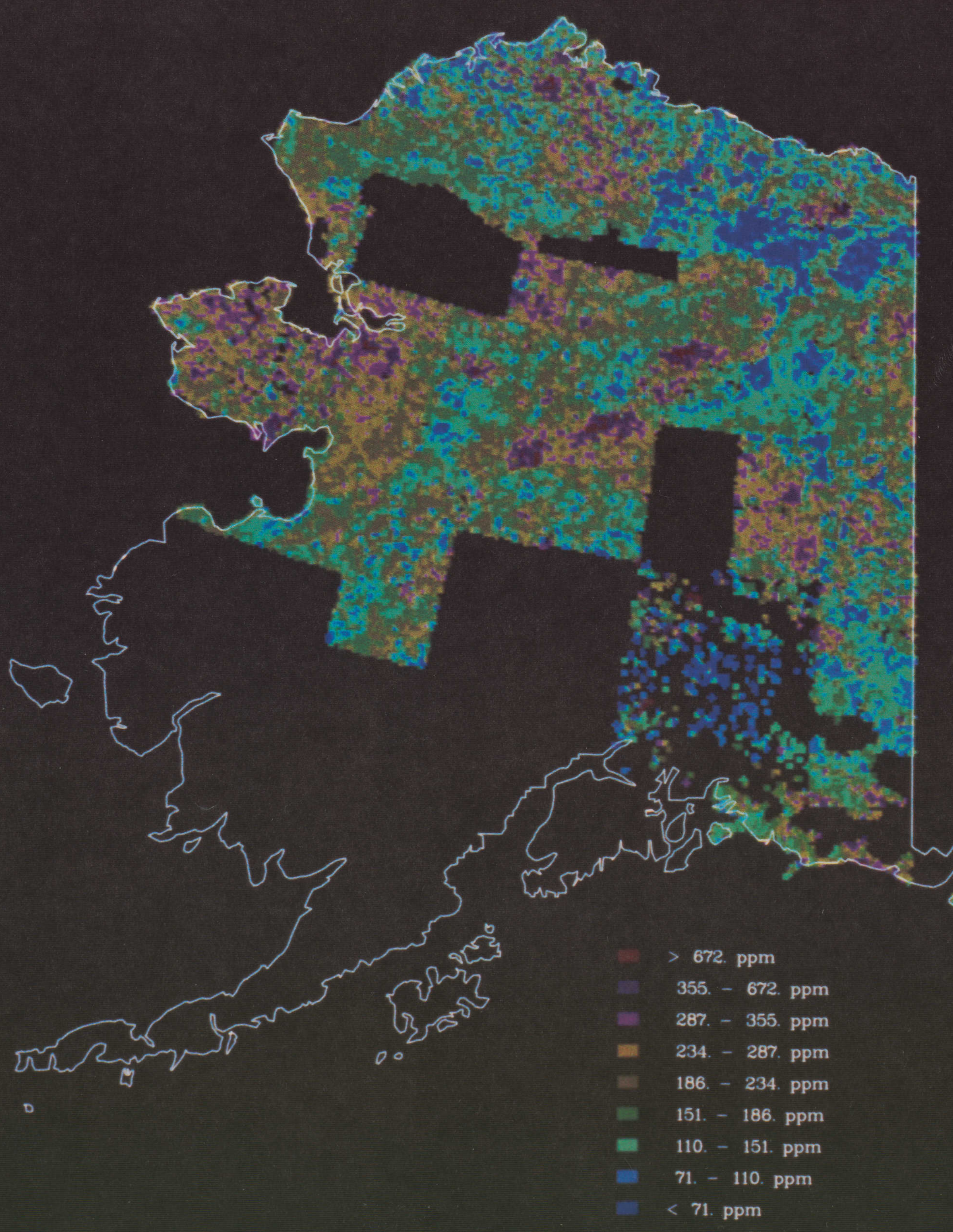

PLATE 43

ZIRCONIUM

For 44526 Values above Detection Limit

$\begin{array}{ll}\text { Mean } & 187.13 \mathrm{ppm} \\ \text { Minimum } & 5.00 \mathrm{ppm} \\ \text { Median } & 168.00 \mathrm{ppm} \\ \text { Maximum } & 25242.00 \mathrm{ppm}\end{array}$
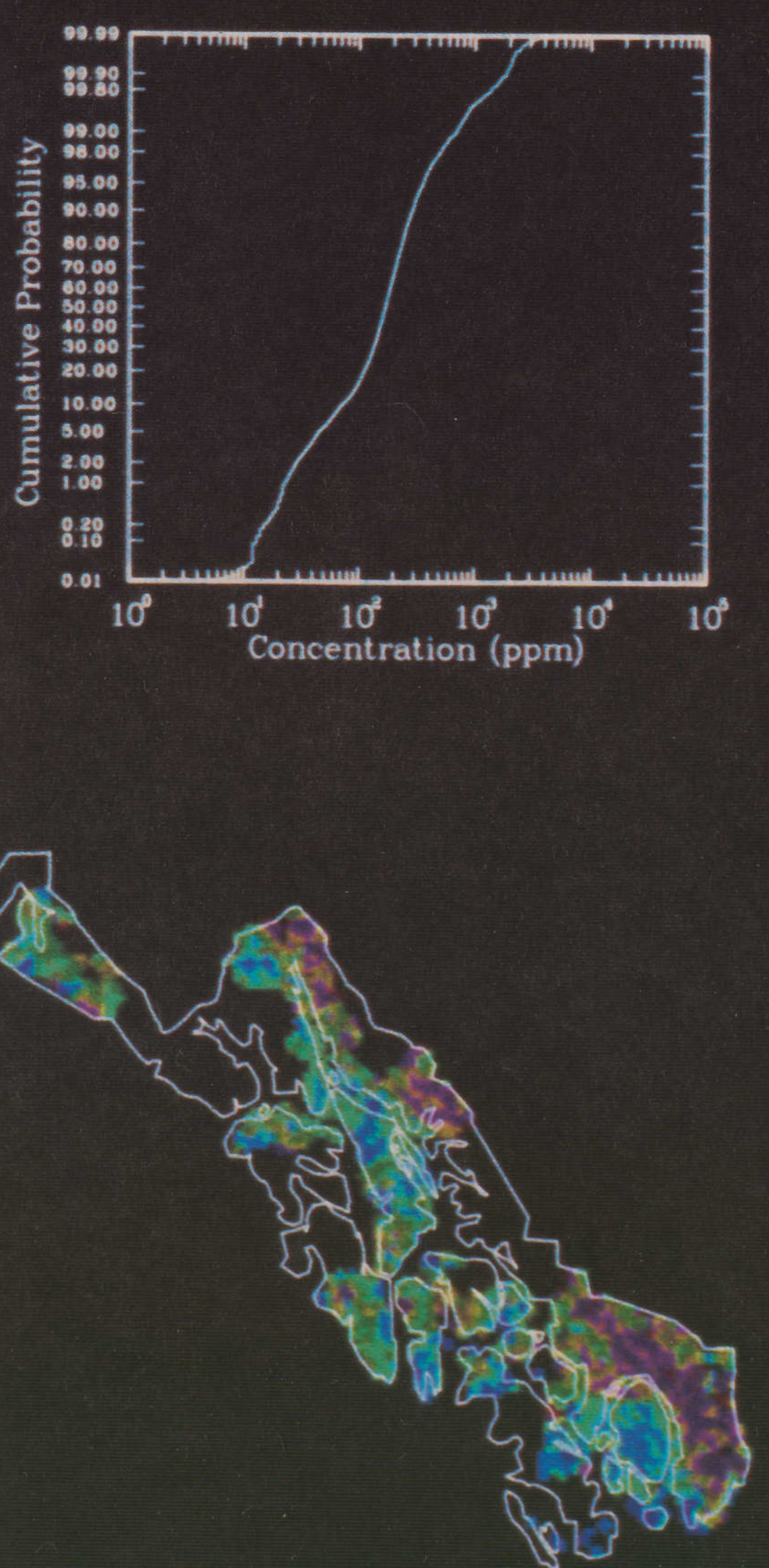
$-52-$

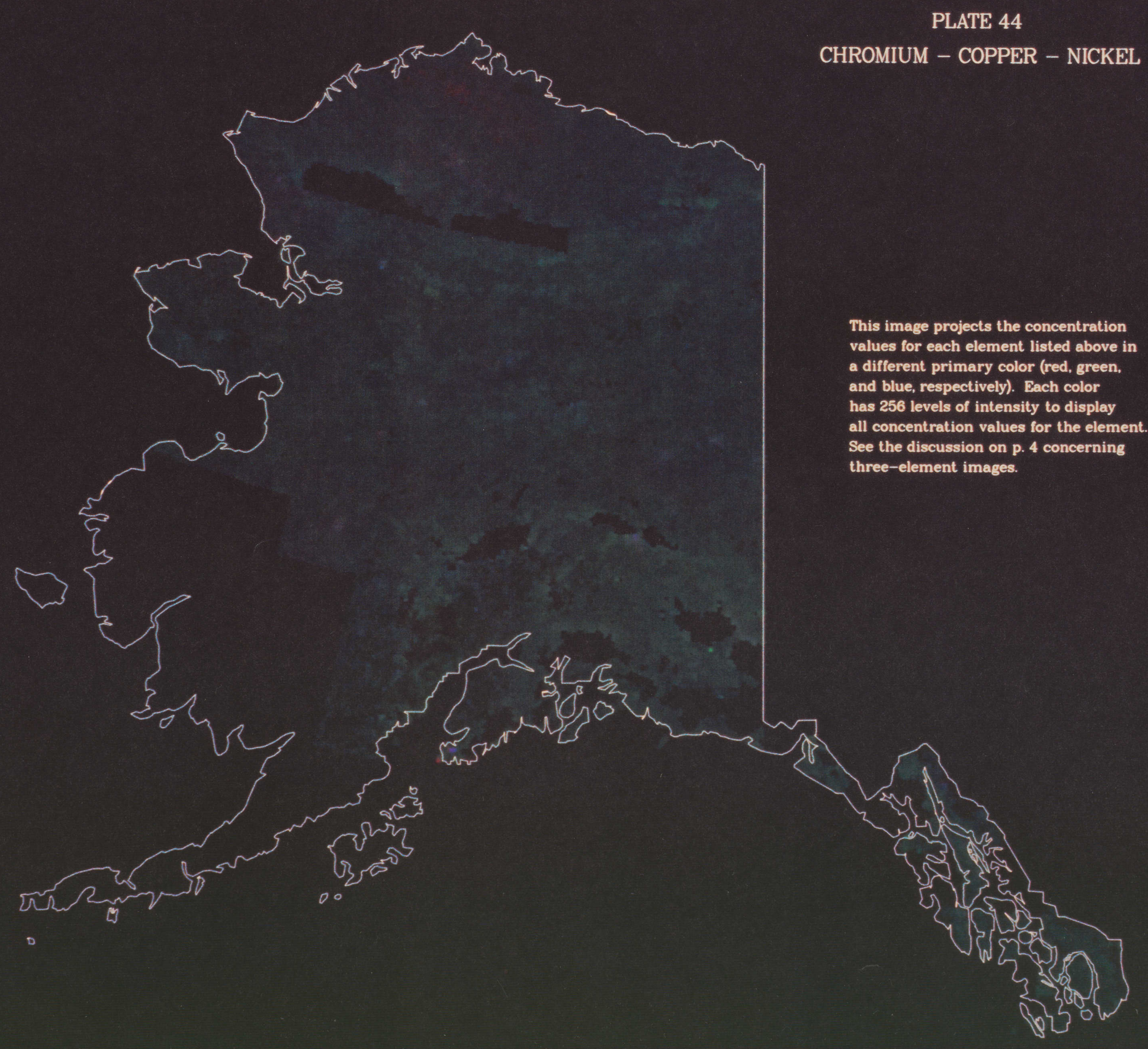


$-53-$

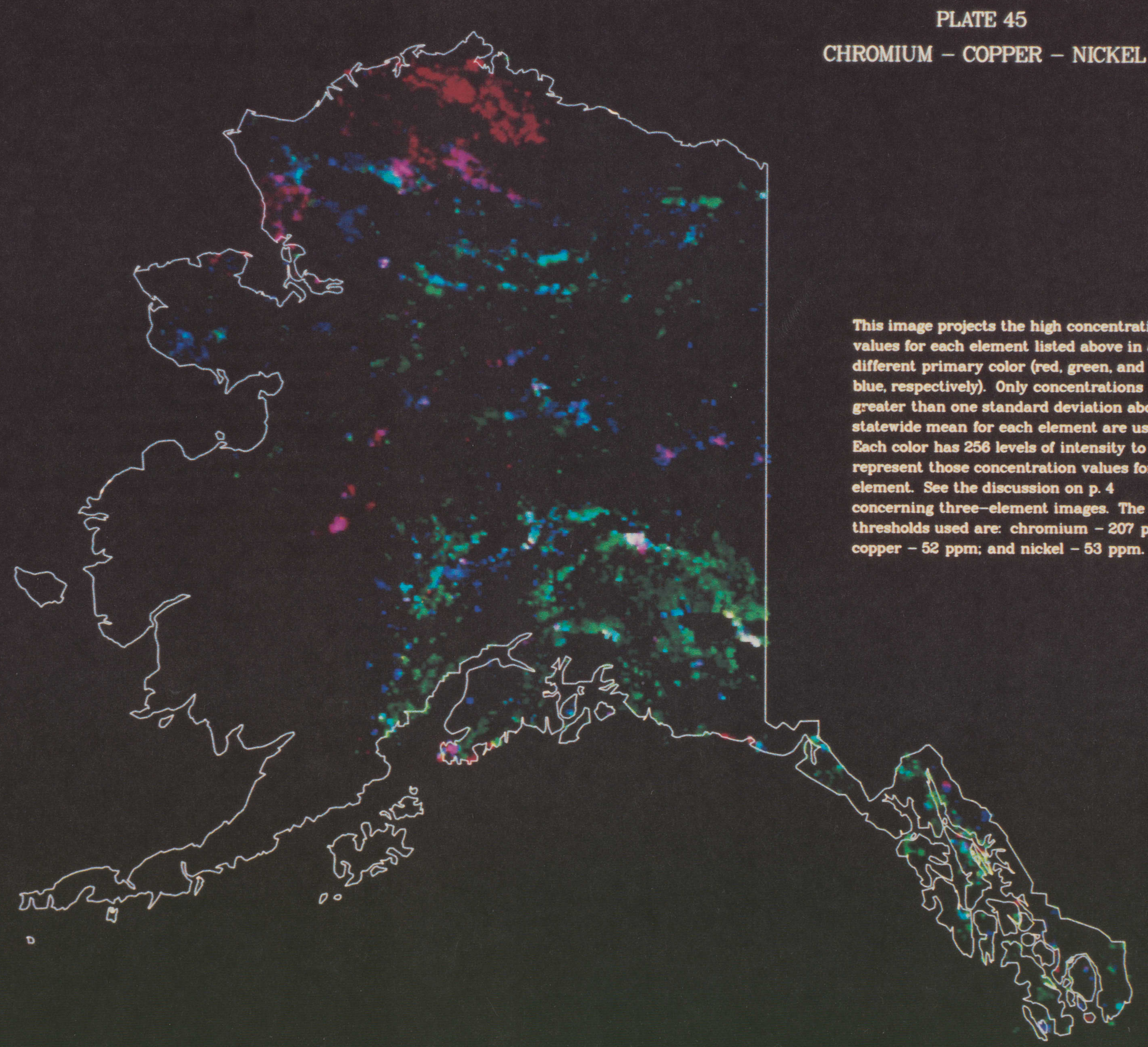




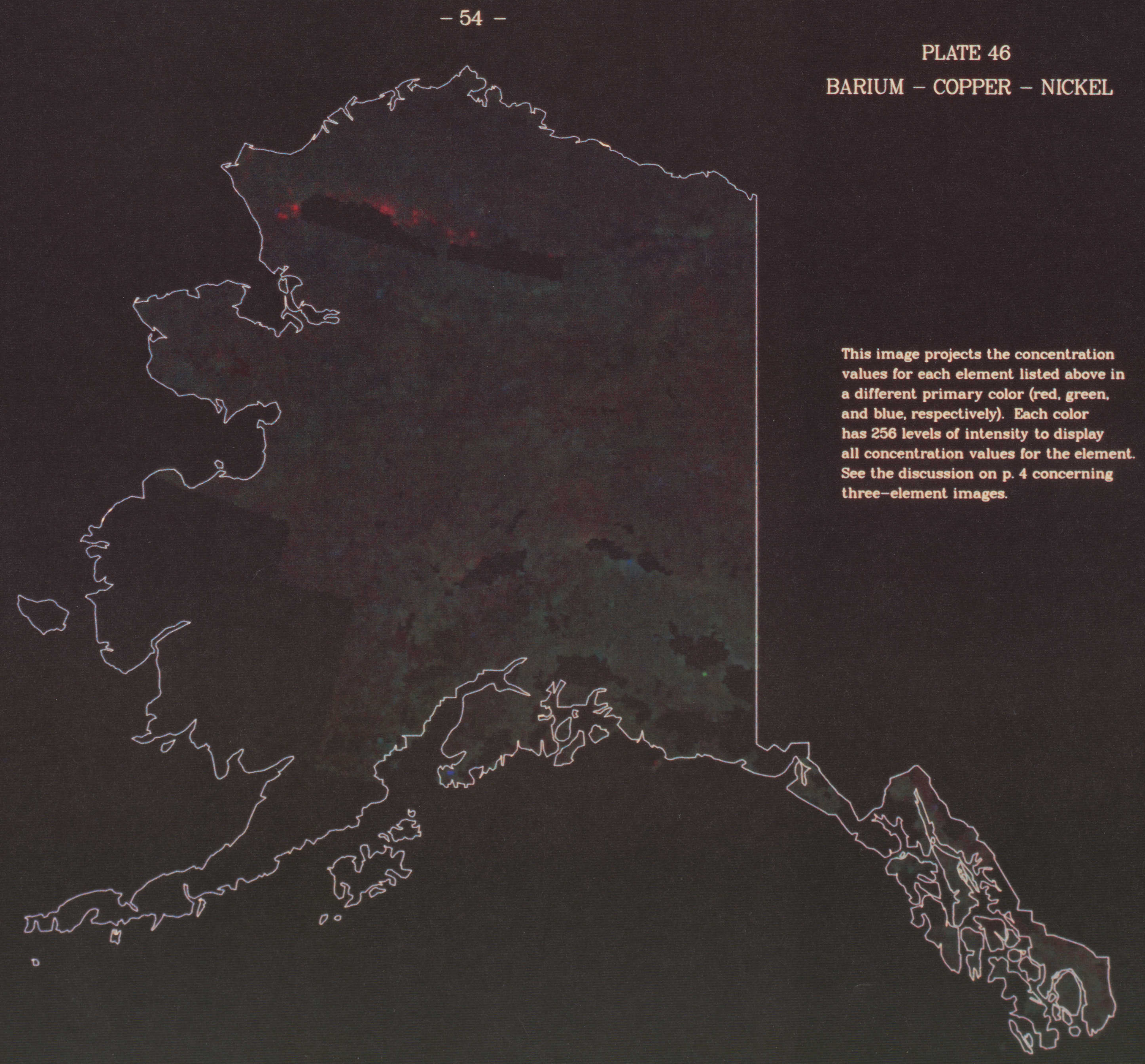




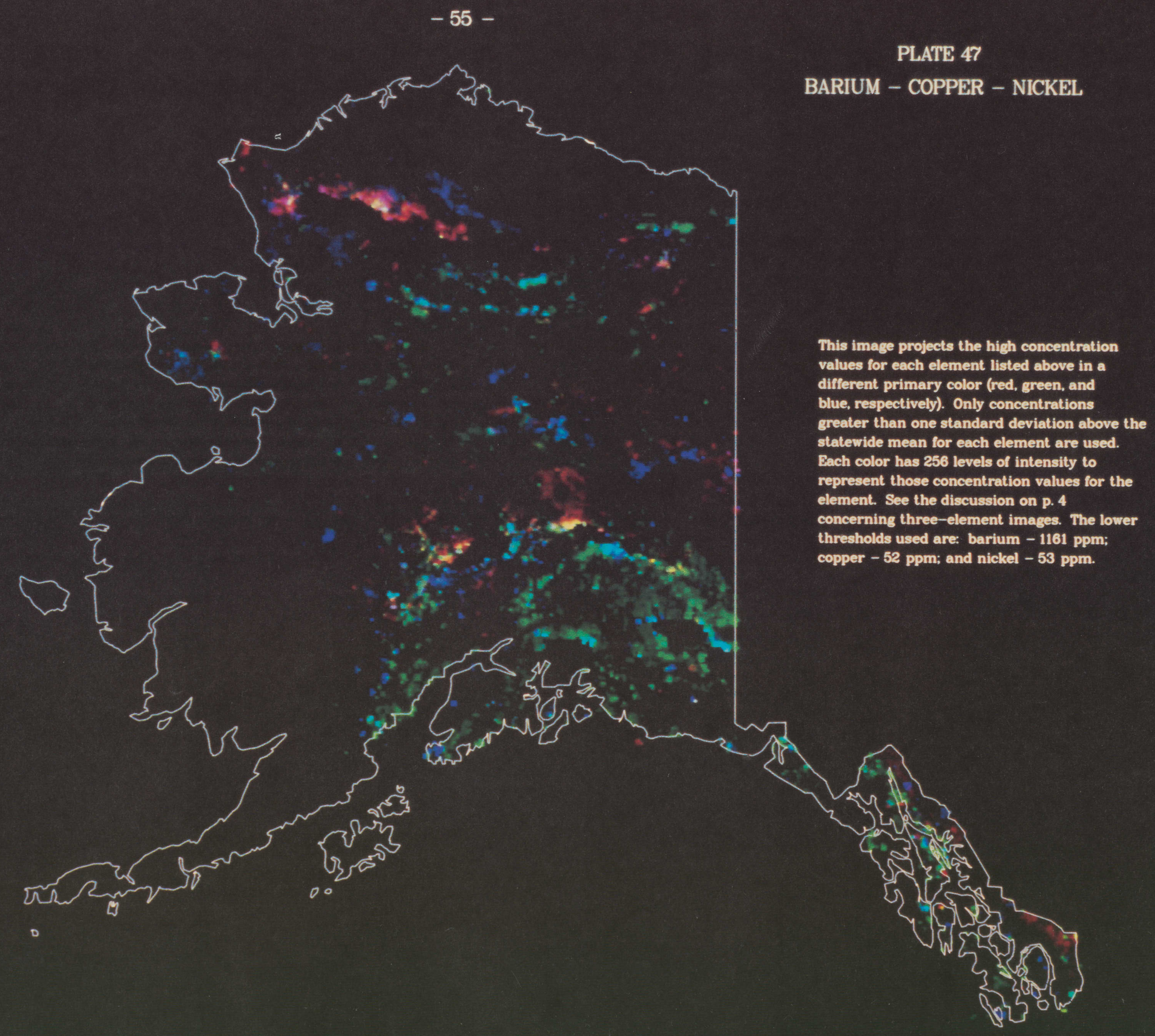


$-56-$

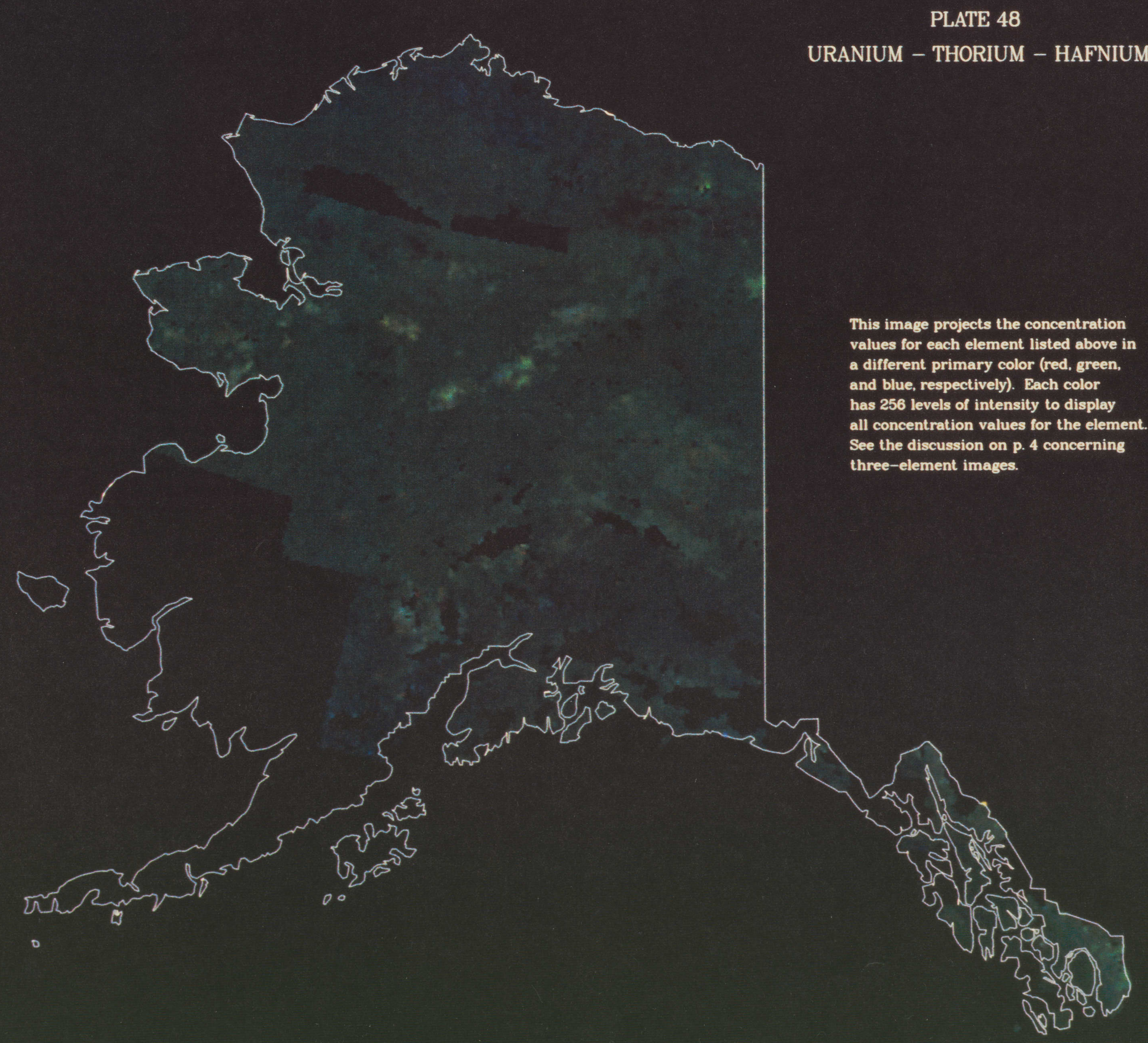




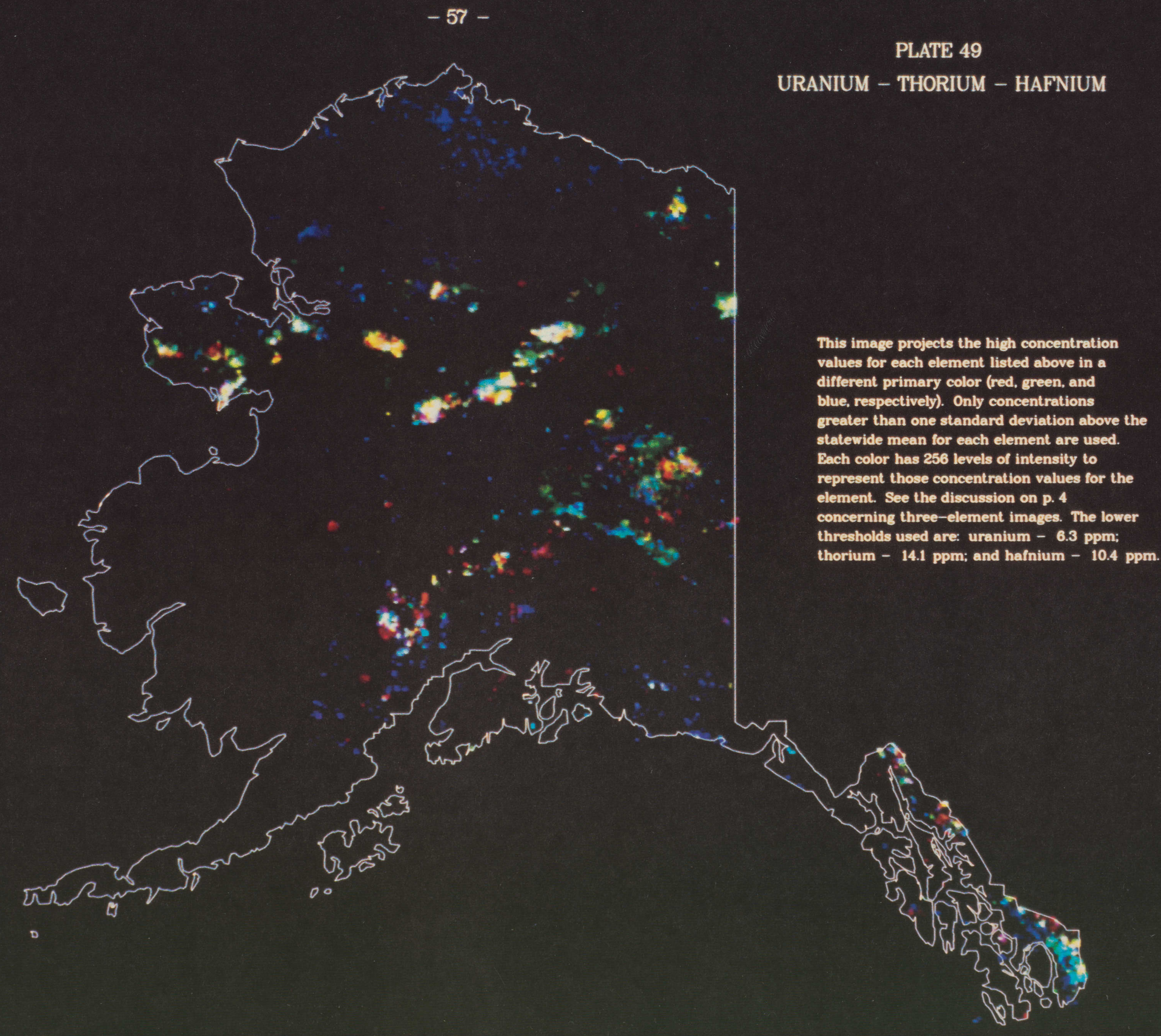




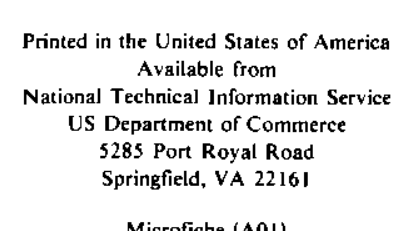

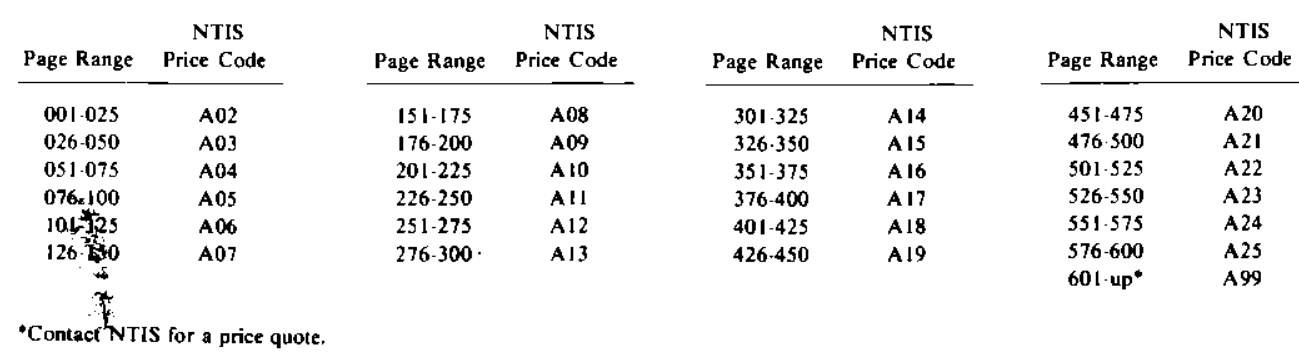




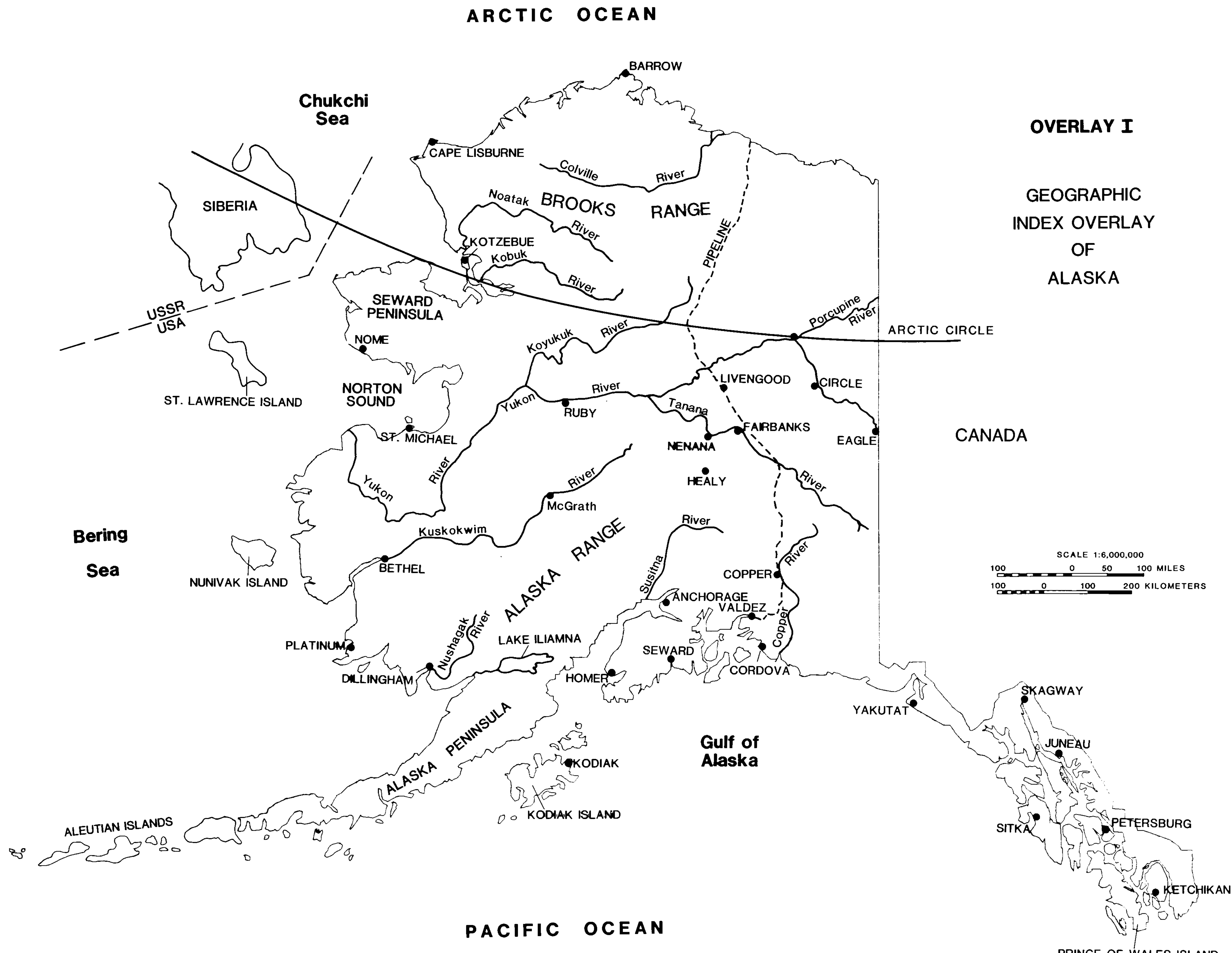

PRINCE OF WALES ISLAND 


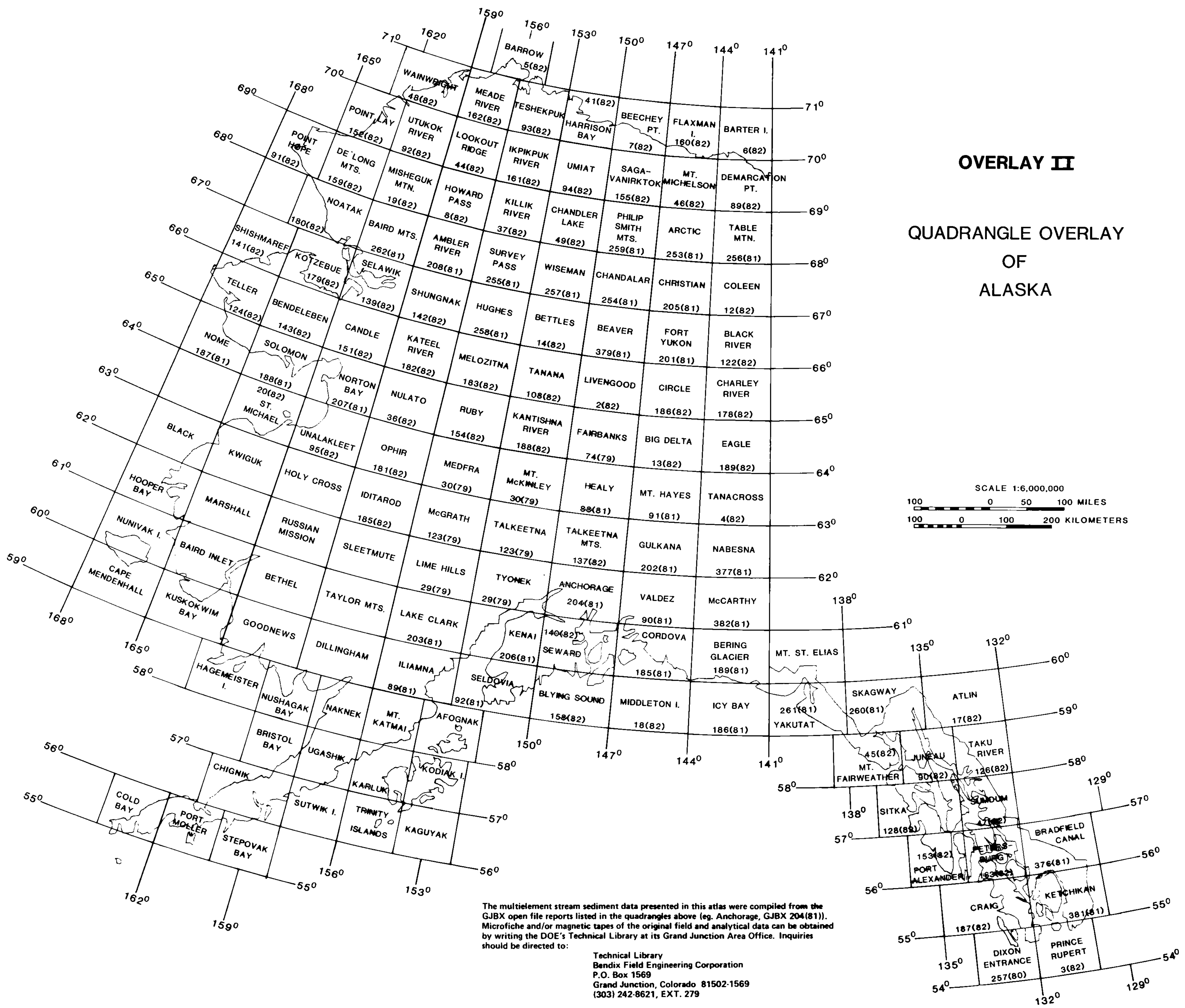




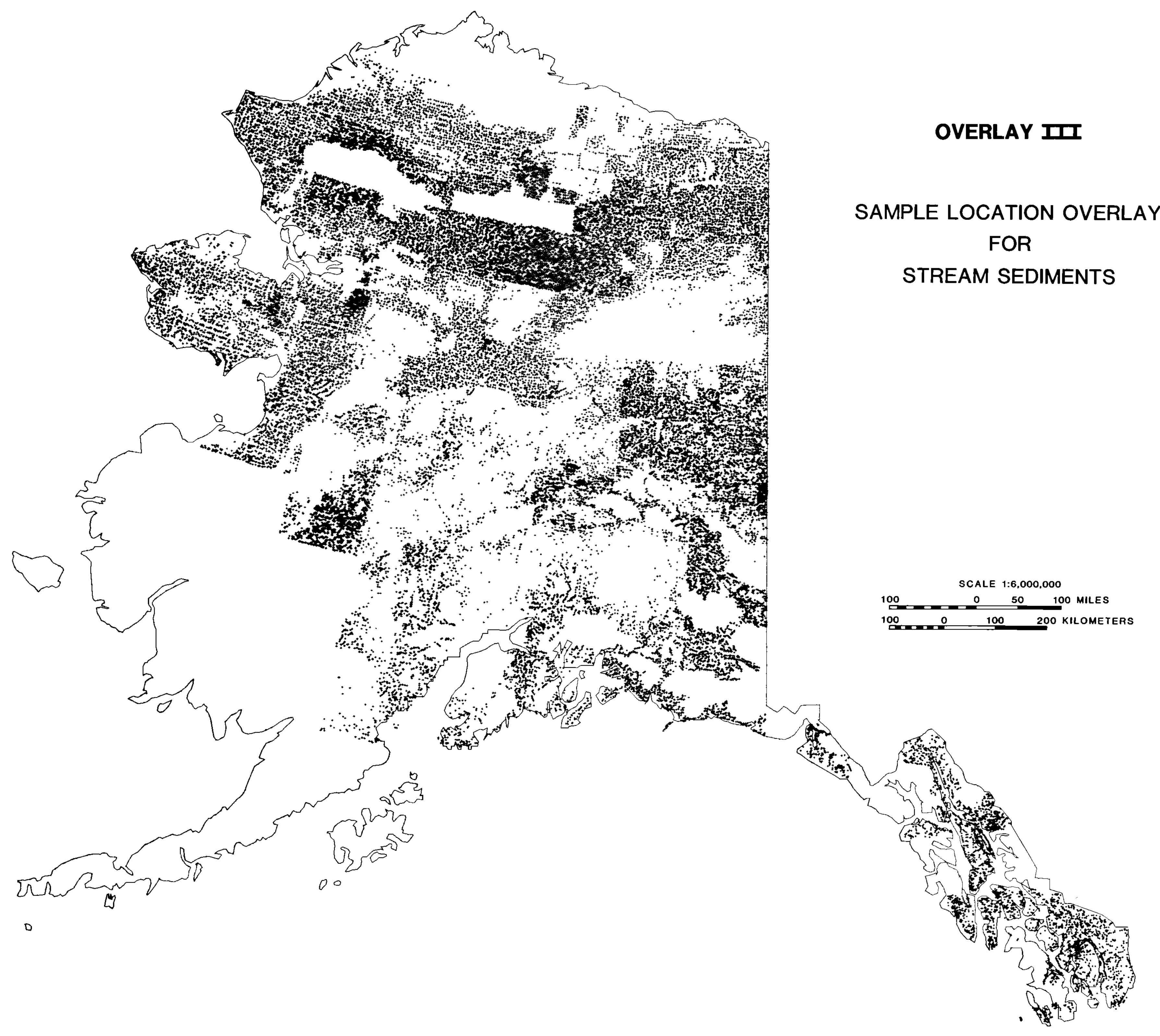




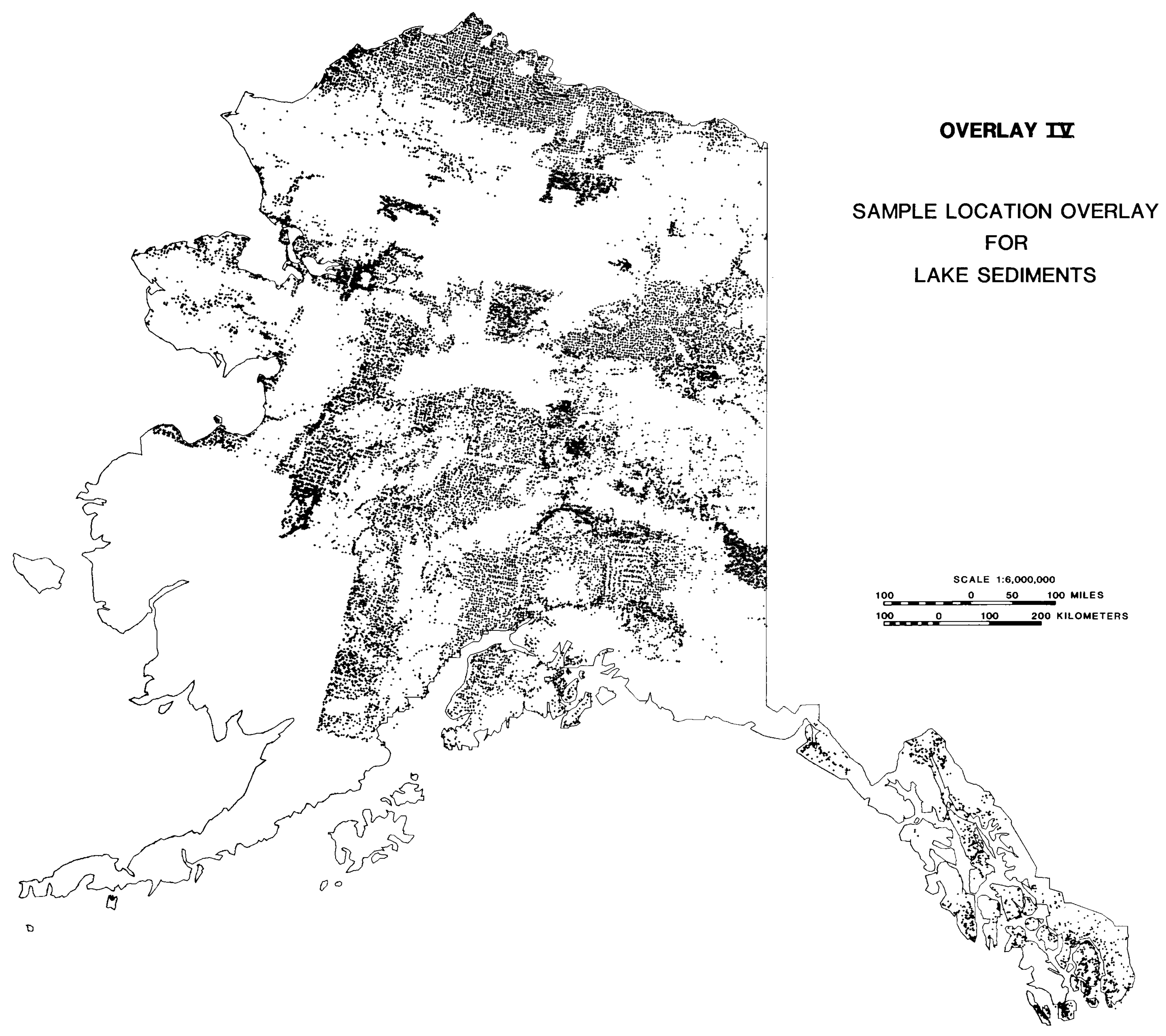




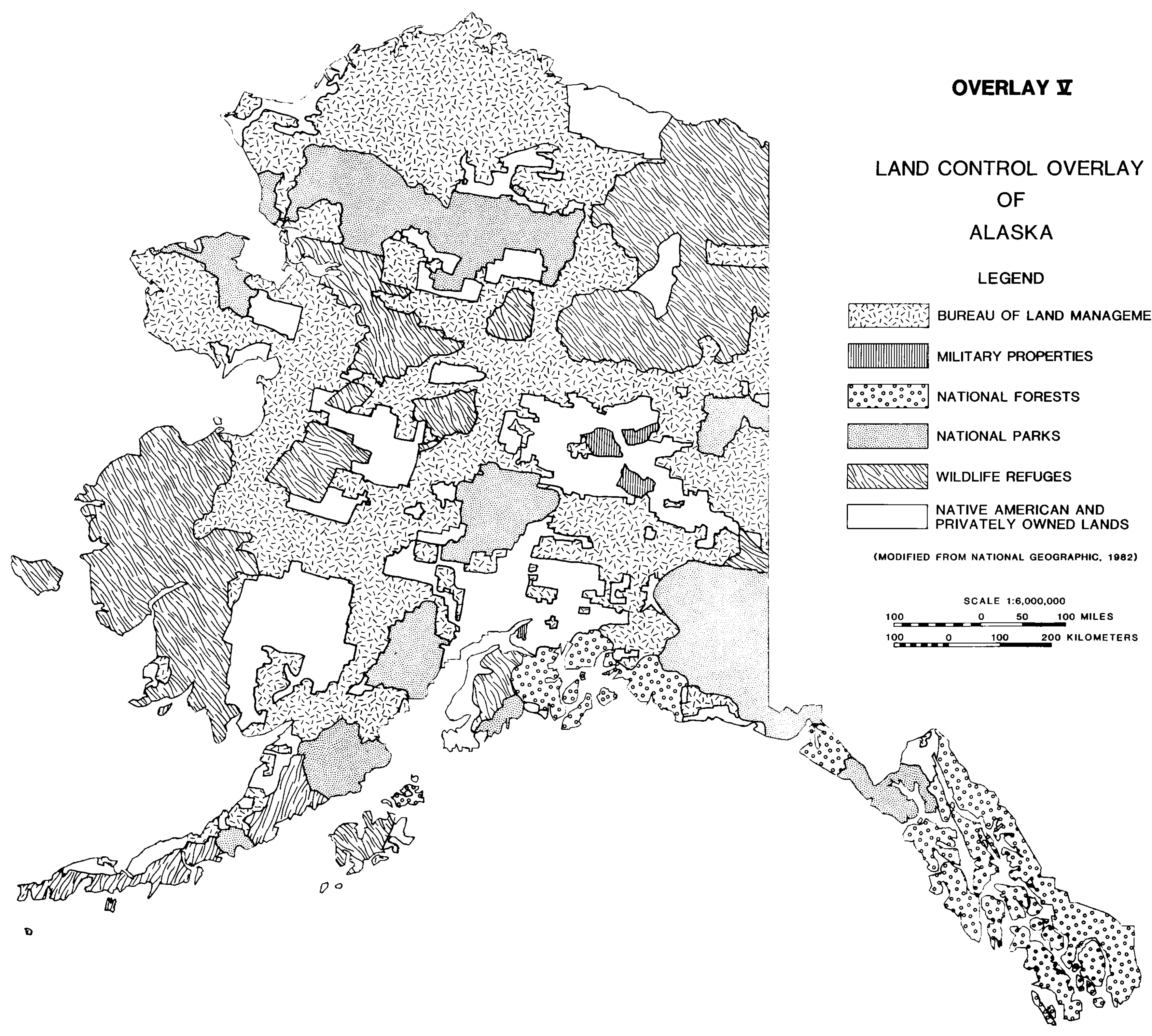




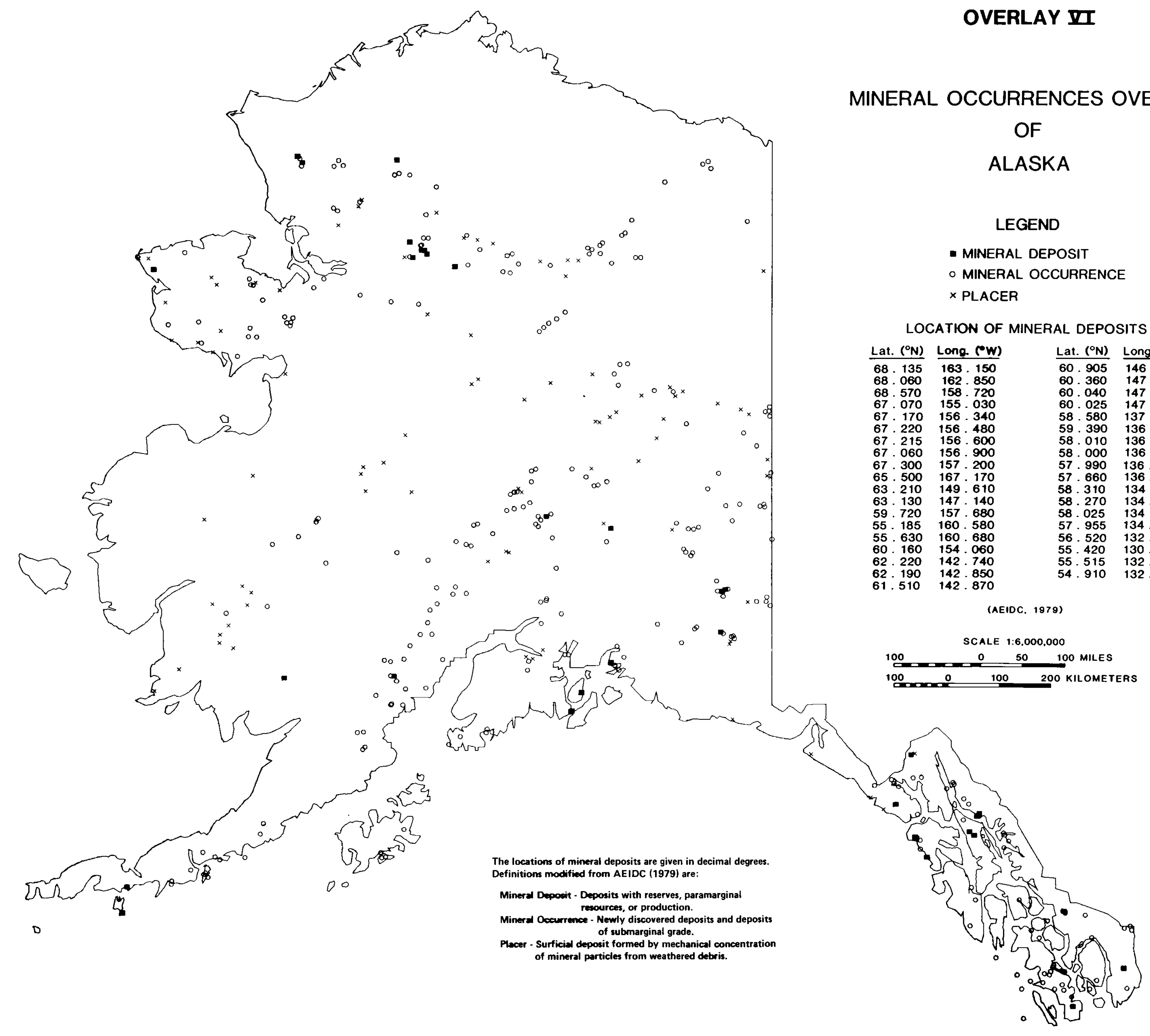




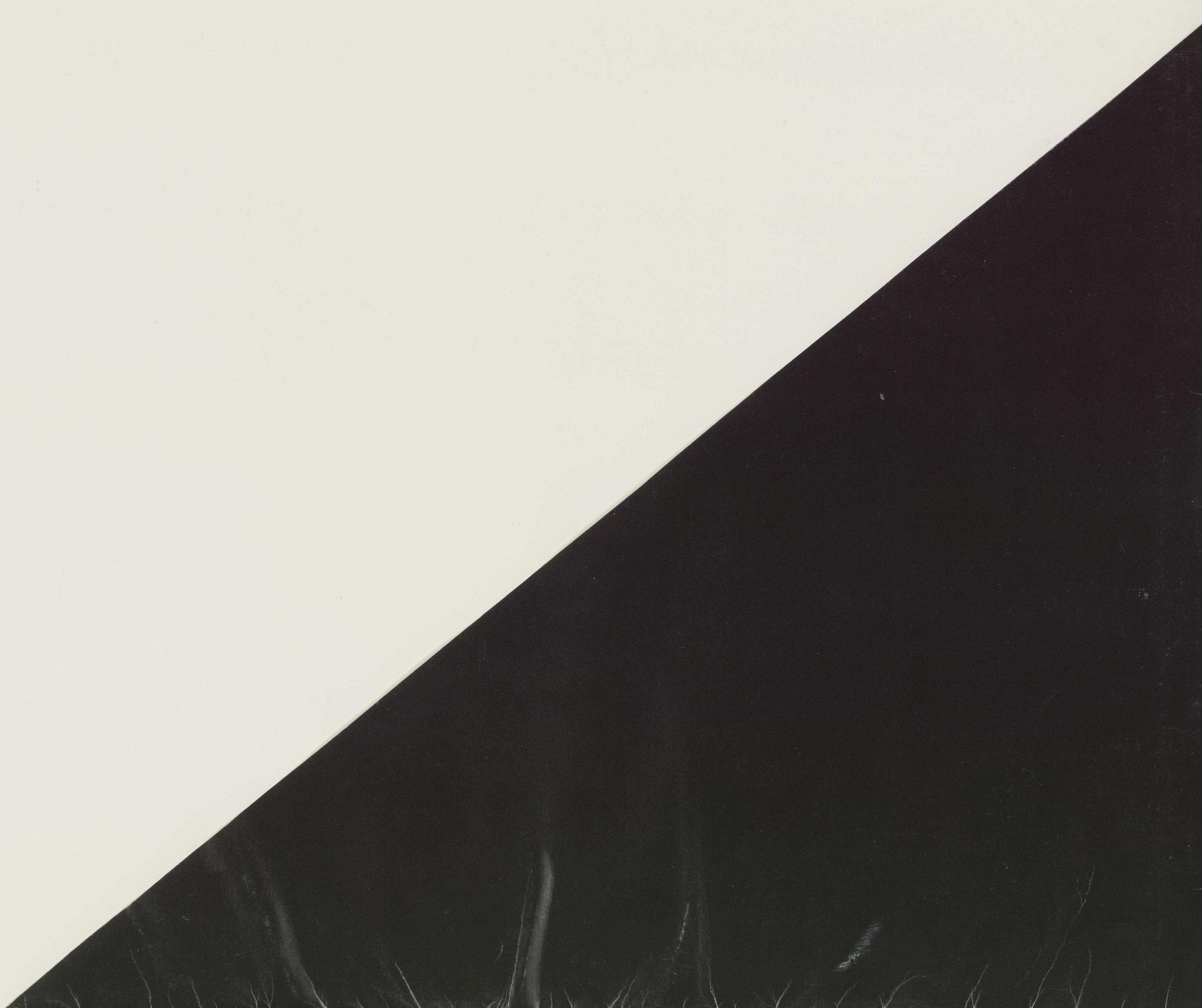


w.

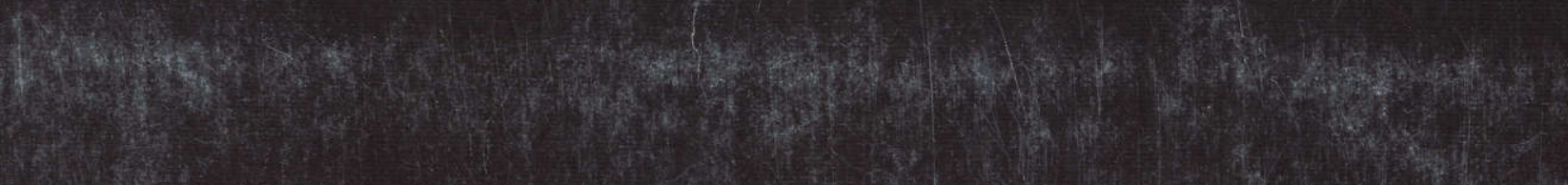

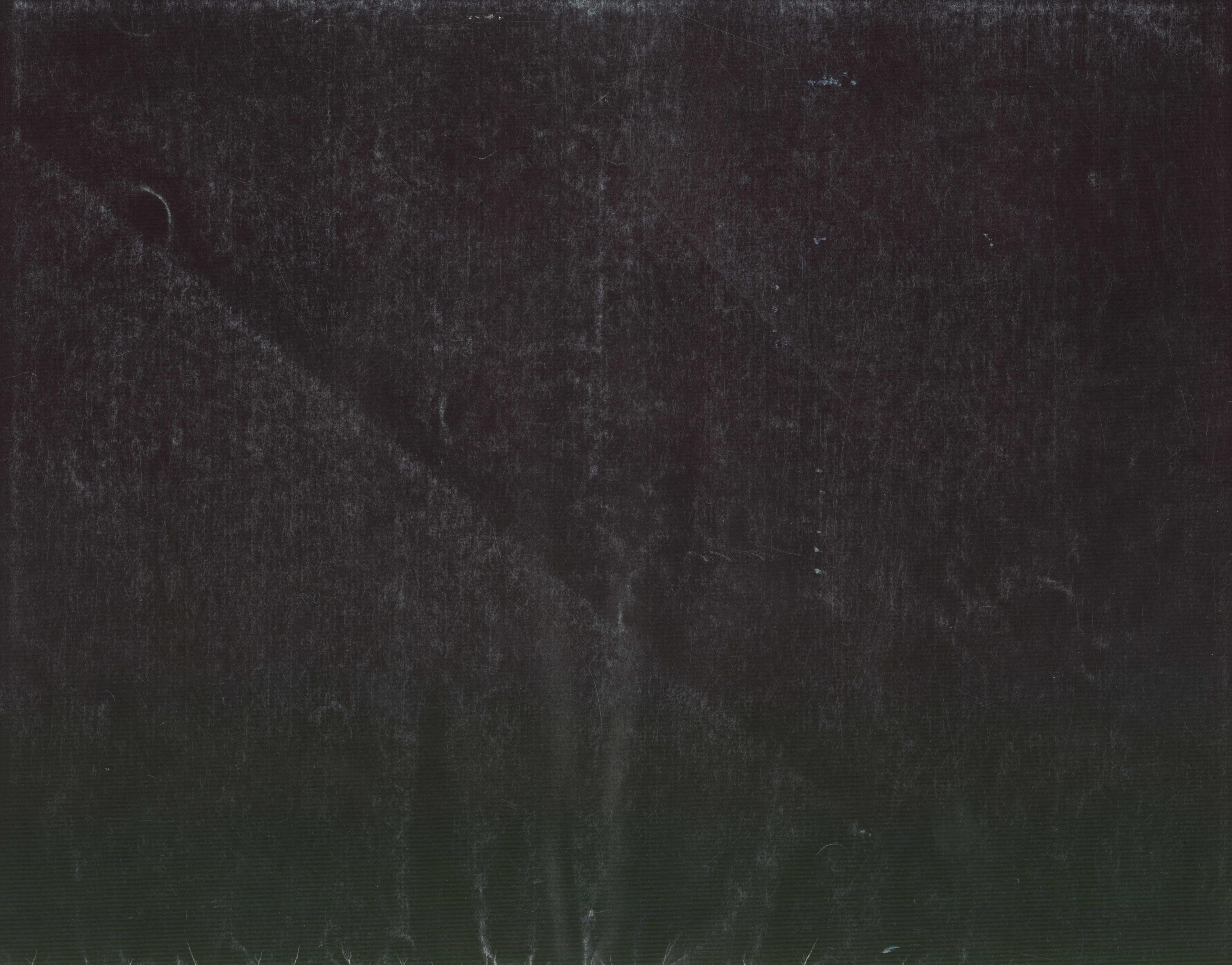

